LUIZ JOSE MARQUES JUNIOR

\title{
ABORDAGEM CONTINGENCIAL ESTRUTURADA DE GESTÃO E O SUCESSO OU FRACASSO DE PROJETOS COMPLEXOS E INCERTOS EM EMPRESAS NO BRASIL
}

Tese apresentada à Escola

Politécnica da Universidade de São Paulo para obtenção do

título de Doutor em Engenharia 
LUIZ JOSE MARQUES JUNIOR

\title{
ABORDAGEM CONTINGENCIAL ESTRUTURADA DE GESTÃO E O SUCESSO OU FRACASSO DE PROJETOS COMPLEXOS E INCERTOS EM EMPRESAS NO BRASIL
}

\author{
Tese apresentada à Escola \\ Politécnica da Universidade de \\ São Paulo para obtenção do \\ título de Doutor em Engenharia
}

Área de Concentração:

Engenharia de Produção

Orientador: Prof. Dr.

Guilherme Ary Plonski 
Este exemplar foi revisado e alterado em relação à versão original, sob responsabilidade única do autor e com a anuência de seu orientador.

São Paulo, 07 de agosto de 2009.

Assinatura do autor

Luiz José Marques Junior

Assinatura do orientador

Guilherme Ary Plonski

\section{FICHA CATALOGRÁFICA}

Marques Junior, Luiz José

Abordagem contingencial estruturada de gestão e o sucesso ou fracasso de projetos complexos e incertos em empresas no Brasil / L.J. Marques Junior. -- ed.rev. -- São Paulo, 2009. $145 \mathrm{p}$.

Tese (Doutorado) - Escola Politécnica da Universidade de São Paulo. Departamento de Engenharia de Produção.

1. Administração de projetos 2. Sistemas e métodos I. Uni versidade de São Paulo. Escola Politécnica. Departamento de Engenharia de Produção II. t. 
Ao Matheus, à Poliana e aos meus pais, 


\section{Agradecimentos}

Ao concluir este trabalho, gostaria de agradecer as pessoas que colaboraram de alguma forma para o seu desenvolvimento e conclusão.

Ao meu filho Matheus, que apesar da pouca idade, parecia compreender as minhas ausências nas festas de aniversário de seus amigos em vários finais de semana de trabalho na tese. À Poliana, pela colaboração para o desenvolvimento do trabalho e por cuidar do nosso filho sempre que precisei me dedicar à tese nos períodos de férias e finais de semana. Aos meus pais, pelo interesse no andamento do trabalho, o que me motivava a seguir adiante nos momentos de angústia.

Ao Prof. Guilherme Ary Plonski pela orientação, pelas oportunidades oferecidas e pela disponibilização de horários para conversas nos finais de semana. Agradeço também ao Prof. Gregório Bouer e ao Prof. Jorge Luiz Biazzi pela ajuda nos ajustes do manuscrito final.

A todos os profissionais das empresas que participaram dos estudos de caso, pela disponibilidade e pela atenção recebida nas entrevistas em seus locais de trabalho. Sem esta contribuição este trabalho não seria possível. 


\section{Resumo}

Os projetos fazem parte da gestão estratégica das empresas na criação e sustentação de suas vantagens competitivas. O portfólio de projetos das empresas é composto por iniciativas relacionadas à busca de inovação e eficiência que envolvem diferentes graus de complexidade e incerteza. Dado o comprovado mau desempenho dos projetos de maneira geral, amplificado pelo maior número de projetos considerados complexos e incertos, novas abordagens de gestão de projetos surgiram em contraponto à abordagem convencional.

Dessa forma, este trabalho analisa as dinâmicas de definição e gestão de projetos complexos e incertos de empresas no Brasil, com intuito de observar como certas práticas ou a ausência delas contribuem para o sucesso ou fracasso dos projetos. Para atender aos objetivos deste trabalho, a metodologia utilizada foi o estudo de múltiplos casos.

Entre os resultados desta pesquisa, os destaques são apresentados a seguir. Primeiro, uma descrição da dinâmica de definição e gestão de projetos complexos e incertos nas empresas estudadas. Segundo, após a descrição das dinâmicas de cada empresa, foi feita uma análise da contribuição das abordagens descritas para o sucesso ou fracasso do projeto. Terceiro, com a descrição das abordagens e suas contribuições para sucesso ou fracasso dos projetos, foi possível entender, criticar e propor melhorias ao modelo contingencial estruturado de Shenhar e Dvir (2007), que foi utilizado como referencial teórico da pesquisa. 


\section{Abstract}

Projects are part of the companies' strategic management, contributing to create and sustain competitive advantages. Companies' project portfolios are composed by initiatives related to innovation and efficiency, which involve different levels of complexity and uncertainty. Considering the poor performance of projects in general, amplified by the increasing number of complex and uncertain projects in companies' portfolios, new managing approaches have been emerging to counterbalance the conventional ones.

Thus, this work analyses the dynamics of definition and management of complex and uncertain projects in companies in Brazil, with purpose of observing how certain aspects of the dynamics contribute to projects' success and failure. In order to meet this purpose, it has been used the multiple cases study methodology.

The results of this research are composed of three parts. First, a description of the dynamics of complex and uncertain projects' definition and management in the companies analyzed. Second, after the description of each company's dynamics, an analysis about its contribution to project's success or failure has followed. Third, after completing the description of the dynamics and their contribution to projects' success and failure, it was possible to understand, criticize and suggest improvements to the Shenhar and Dvir (2007) structured and adaptive project management approach, which was used as the theoretical reference for this research. 


\section{SUMÁRIO}

1. Introdução.

2. Objetivos

2.1. Propósito da pesquisa. 05

2.2. Questões de pesquisa. 05

2.3. Resultados esperados da pesquisa.................................................... 05

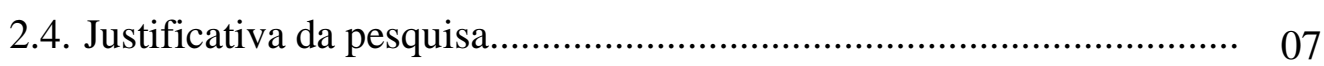

3. Fundamentos teóricos............................................................................. 09

3.1. Importância e desempenho dos projetos........................................... 09

3.2. Abordagem tradicional de gestão de projetos..................................... 13

3.3. Abordagem contingencial de gestão de projetos................................. 21

3.3.1. Classificação dos projetos...................................................... 21

3.3.2. Adaptação da gestão de projetos............................................. 23

3.3.3. Critérios de sucesso dos projetos........................................... 26

3.4. Modelo teórico da pesquisa............................................................ 29

3.4.1. Identificação do tipo de projeto............................................ 31

3.4.2. Critérios de sucesso............................................................. 33

3.4.3. Adaptação da gestão........................................................... 34

4. Metodologia.......................................................................................................... $\quad 37$

4.1. Tipo de estudo............................................................................. 37

4.2. Seleção dos casos.......................................................................... 39

4.3. Protocolo de coleta de dados............................................................. 41

4.4. Instrumento de coleta de dados....................................................... 42

4.5. Limitações do método de pesquisa.................................................... 44

5. Apresentação dos casos analisados.......................................................... 46

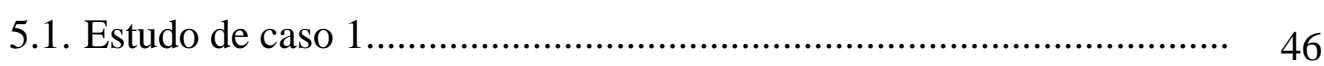

5.1.1. Início dos projetos.......................................................... 48

5.1.2. Estratégias de implantação.................................................... 51

5.1.3. Critérios de sucesso............................................................. 53

5.2. Estudo de caso 2.................................................................... 56 
5.2.1. Início dos projetos.

5.2.2. Estratégias de implantação.................................................... 60

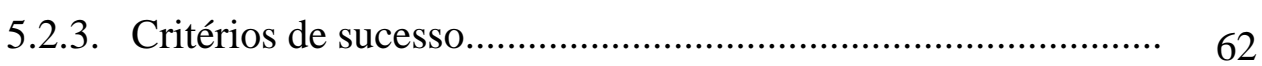

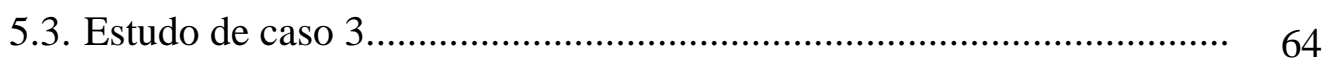

5.3.1. Início dos projetos.......................................................... 66

5.3.2. Estratégias de implantação.................................................... 67

5.3.3. Critérios de sucesso........................................................... 70

5.4. Estudo de caso 4..................................................................... 73

5.4.1. Início dos projetos................................................................ 75

5.4.2. Estratégias de implantação................................................... 77

5.4.3. Critérios de sucesso.............................................................. 78

5.5. Estudo de caso 5................................................................... 82

5.5.1. Início dos projetos............................................................. 84

5.5.2. Estratégias de implantação................................................... 85

5.5.3. Critérios de sucesso............................................................. 87

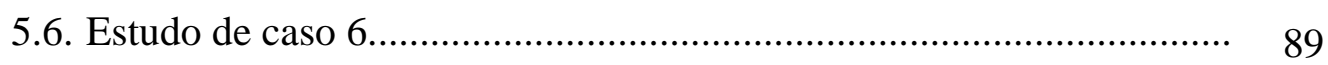

5.6.1. Início dos projetos............................................................ 90

5.6.2. Estratégias de implantação.................................................. 92

5.6.3. Critérios de sucesso............................................................. 94

6. Análise dos resultados.......................................................................................... 97

6.1. Dinâmica de definição e gestão de projetos complexos e incertos..... 97

6.1.1. Identificação do tipo de projeto............................................. 97

6.1.2. Critérios de sucesso........................................................... 101

6.1.3. Adaptação da gestão - organização....................................... 107

6.1.4. Adaptação da gestão - gestão dos requisitos............................. 110

6.1.5. Adaptação da gestão - criação e construção do produto........... 113

6.1.6. Adaptação da gestão - re-planejamento do projeto.................... 116

6.2. Contribuição das abordagens de gestão para o sucesso ou fracasso dos projetos complexos e incertos nas empresas................................. 119

6.2.1. Identificação do tipo de projeto.............................................. 119

6.2.2. Critérios de sucesso............................................................. 121

6.2.3. Adaptação da gestão............................................................. 123 
6.3. Análise crítica do modelo de Shenhar e Dvir (2007), no contexto das empresas estudadas.

7. Conclusões................................................................................................................... 131

7.1. Dinâmica de definição e gestão de projetos complexos e incertos e suas contribuições para o sucesso ou fracasso de projetos.

7.2. Entendimento, validade e aprimoramento da abordagem de Shenhar e Dvir (2007).

7.3. Recomendações para pesquisas futuras. 136

8. Referências Bibliográficas. 


\section{Lista de Figuras}

Figura 1 Relações entre questões e resultados da pesquisa...... 6

Figura 2 Etapas do método de estudo de caso...................... 38

Figura $3 \quad$ Matriz de posicionamento de iniciativas da empresa 1.. 50

Figura $4 \quad$ Sistema corporativo global da empresa $2 \ldots \ldots \ldots \ldots \ldots \ldots . . . . . .58$

Figura 5 Composição acionária da Holding - Empresa 3.......... 64

Figura $6 \quad$ Portfólio de projetos da empresa $4 \ldots \ldots \ldots \ldots \ldots \ldots \ldots \ldots \ldots . \ldots \ldots \ldots$

Figura $7 \quad$ Processos em projetos de engenharia da empresa 5... 84 


\section{Lista de Tabelas}

Tabela 1 Modelo Teórico da pesquisa...................................... 30

Tabela 2 Critérios de sucesso conforme o grau de inovação ....... 33

Tabela 3 Critérios de sucesso conforme o grau de incerteza tecnológica.......................................................... 34

Tabela 4 Pontos de preocupação na gestão de projetos nas dimensões de classificação.

Tabela 5 Itens necessários para adaptação do ciclo de vida de projeto............................................................... 36

Tabela $6 \quad$ Tipos básicos de projetos de estudo de caso................ 40

Tabela 7 Setor econômico das empresas, quantidade de entrevistas e área interna......................................... 41

Tabela 8 Abordagem de gestão de projetos - Empresa 1........... 55

Tabela 9 Unidades de negócio - Empresa 2............................. 56

Tabela 10 Abordagem de gestão de projetos - Empresa 2............ 63

Tabela 11 Abordagem de gestão de projetos - Empresa 3........... 72

Tabela 12 Abordagem de gestão de projetos - Empresa 4............ 81

Tabela 13 Abordagem de gestão de projetos - Empresa 5............ 88

Tabela 14 Abordagem de gestão de projetos - Empresa 6........... 96

Tabela 15 Pontos observados nas empresas - categoria: identificação do tipo de projeto.................................... 100

Tabela 16 Pontos observados nas empresas - categoria: critérios de sucesso do projeto............................................ 106

Tabela 17 Pontos observados nas empresas - categoria: adaptação da gestão - organização............................. 109

Tabela 18 Pontos observados nas empresas - categoria: adaptação da gestão - gestão de requisitos.................. 112

Tabela 19 Pontos observados nas empresas - categoria: adaptação da gestão - criação e construção do produto.

Tabela 20 Pontos observados nas empresas - categoria: adaptação da gestão - replanejamento.

Tabela 21 Pontos de convergência observados nas empresas..... 126 


\section{Lista de Siglas e Abreviaturas}

$3 \mathrm{M}$

ATR

BI

BOK

BOVESPA

CAPEX

COP

CPM

C/SCSC

EBITDA

ERP

EVMS

EVTE

FEL

Gantt

GE

GEAD

GERT

GP

HP

IBM

IPA
Empresa do setor químico

Açúcar Total Recuperável

Business Intelligence

Body of Knowledge

Bolsa de Valores de São Paulo

Capital Expenses

Controle de Orçamento Planejado

Critical Path Method

Cost/Schedule Control Systems Criteria

Earnings Before Interests, Taxes, Depreciation and Amortization

Enterprise Resource Planning

Earned Value Management System

Estudo de Viabilidade Técnico-Econômica

Front End Loading

De Henry Gantt

General Electric

Gestão de Ativos Disponíveis

Graphical Evaluation and Review Technique

Gestão de Projetos

Hewlett-Packard

Industrial Business Machine

Independent Project Analysis 


$\begin{array}{ll}\text { Latibex } & \text { Bolsa de Madrid } \\ \text { NYSE } & \text { New York Stock Exchange } \\ \text { OBS } & \text { Organizational Breakdown Structure } \\ \text { ON } & \text { Ações Ordinárias } \\ \text { P\&D } & \text { Pesquisa e Desenvolvimento } \\ \text { PERT } & \text { Program Evaluation and Review Technique } \\ \text { PMBOK } & \text { Project Management Body of Knowledge } \\ \text { PMI } & \text { Project Management Institute } \\ \text { PMO } & \text { Project Management Office } \\ \text { PN } & \text { Ações Preferenciais } \\ \text { SISGEP } & \text { Sistema de Gestão de Projetos } \\ \text { SWOT } & \text { Strenghts, Weaknesses, Oportunities and Threats } \\ \text { TI } & \text { Tecnologia da Informação } \\ \text { WBS } & \text { Work Breakdown Structure }\end{array}$




\section{Capítulo 1}

\section{Introdução}

O aumento da competição, as constantes inovações e a evolução tecnológica submetem as empresas a constantes mudanças na busca da manutenção, ou criação de vantagens competitivas. A globalização dos mercados tem forçado as empresas a atender demandas locais e a competir com baixo custo no mundo todo. A alta demanda por crescimento e inovação traz a necessidade de maior velocidade no desenvolvimento e lançamento de novos produtos/serviços e a evolução da tecnologia leva a constantes investimentos em infra-estrutura para acompanhar as demandas de crescimento e competição (SHENHAR e DVIR, 2007; CLELAND, 1994).

Neste ambiente competitivo dos negócios, os projetos têm papel importante na gestão estratégica das organizações. Os projetos são os vetores das mudanças, da implementação das estratégias e das inovações que trazem vantagens competitivas para as empresas. Com a alta demanda por crescimento e inovação, a fatia das operações de rotina nas organizações tem declinado, enquanto a fatia dos projetos tem aumentado (SHENHAR e DVIR, 2007; CLELAND, 1994).

Apesar da importância cada vez maior dos projetos nas organizações, a maioria dos projetos não cumpre suas metas. Entregar projetos que atendam as metas de prazo, custo e especificações planejadas e que atendam os objetivos de negócio que o justificaram é ainda um desafio a ser superado nas empresas. Pesquisas indicam que somente $28 \%$ dos projetos de tecnologia da informação tem sucesso, que projetos de construção e reforma têm atrasos médios de $103 \%$ e que somente um em quatro produtos desenvolvidos se tornam um sucesso comercial (CHAOS REPORT, 1995; MARQUES JR, 2000; SHENHAR e DVIR, 2007). 
As causas dos insucessos dos projetos são diversas. Marques Jr (2000) aponta fatores ligados ao planejamento como causas mais freqüentes dos problemas nos projetos de construção na área pública. Hartman e Ashrafi (2002) definem causas críticas: falta de definição do que seja sucesso, falta de apoio da alta administração, falta de métricas para controle e falta de alinhamento dos interessados com critérios de sucesso. Na pesquisa KPMG (2002), as causas são o planejamento deficiente, a falta de alinhamento com o negócio e a falta de envolvimento da alta administração. Black (1996), em pesquisa com 70 engenheiros, aponta a falta de definição no início do projeto como a causa principal de atrasos e custos acima do orçamento. Em projetos de web design, Fichter (2003), relaciona as principais causas de problemas: falta de envolvimento do usuário, falta de apoio dos executivos da empresa, falta de definição clara dos requisitos e planejamento.

Para atacar essas causas, o foco predominante foi o desenvolvimento de técnicas e ferramentas de planejamento e controle que racionalizam e normatizam a gestão dos projetos. A premissa desta abordagem é que os projetos tem mais chance de sucesso ao seguirem um conjunto de regras comuns. No entanto, os críticos dessa abordagem predominante consideram que o uso efetivo de tais técnicas e ferramentas pressupõe um cenário de negócios estável e previsível, cenário este não condizente com a realidade atual. O cenário atual é caracterizado pela instabilidade e imprevisibilidade, onde os projetos são influenciados pelas dinâmicas do ambiente, da tecnologia e dos mercados (WILLIAMS, 2005; MAYLOR, 2001).

A proposição dos críticos da abordagem predominante de racionalismo e normatização é que os projetos devem ser reconhecidos como diferentes entre si e que a gestão de cada projeto deve ser adaptada para contemplar essas diferenças em relação aos seus objetivos, tarefas e ambiente. A premissa é que a adoção de uma abordagem contingencial aumenta a chance de sucesso dos projetos de maior complexidade e incerteza nas organizações.

É evidente que as duas visões têm pontos a favor e contra. A abordagem racional e normativa pode trazer padronização e simplificação. Por outro lado, a universalização de sua utilização é questionável, dado o cenário atual de 
negócios. A abordagem adaptativa ou contingencial pode ser mais efetiva, dada a maior customização de cada projeto. Por outro lado, dado o grande número de projetos nos portfólios das empresas, torna-se inviável utilizar uma solução única para gestão de cada projeto.

Levando em consideração os pontos a favor e contra cada uma das abordagens, Shenhar e Dvir (2007) propuseram uma abordagem adaptativa que diferencia os projetos e ao mesmo tempo continua utilizando normatizações e padronizações.

Dado que a abordagem proposta por Shenhar e Dvir (2007) é nova e despertou interesse entre praticantes e acadêmicos, esta pesquisa procurou verificar se as premissas de construção e utilização da abordagem se confirmam à luz da realidade de empresas no Brasil que tenham projetos complexos e incertos em seus portfólios.

Portanto, o objetivo desta pesquisa é entender, críticar e propor melhorias do modelo de abordagem gerencial sugerido por Shenhar e Dvir (2007) para aumentar as chances de sucesso de projetos complexos e incertos em empresas no Brasil.

Esse e outros objetivos são especificados no capítulo 2 deste trabalho, onde são apresentadas também as questões de pesquisa e os resultados esperados, assim como a justificativa do tema.

No capítulo 3 é apresentada a revisão bibliográfica que representa o fundamento teórico deste trabalho. Inicialmente é feita uma discussão sobre a importância e o desempenho dos projetos dentro do ambiente organizacional. A seguir são apresentados os aspectos que caracterizam a abordagem tradicional de gestão de projetos. As abordagens adaptativas ou contingenciais são discutidas a seguir. Ao final do capítulo é apresentado o modelo teórico utilizado para a pesquisa objeto deste trabalho.

O capítulo 4 apresenta a metodologia de pesquisa adotada para este trabalho. Foram utilizados estudos de caso com empresas que atuam no Brasil e tenham projetos complexos e incertos em seus portfólios. Inicialmente é feita uma justificativa para o tipo de estudo adotado, seguido 
pela apresentação do método de coleta dos dados, a seleção dos casos, o instrumento de pesquisa e as limitações do estudo.

No capítulo 5 é feita a apresentação dos casos estudados, com descrição de cada empresa e os aspectos investigados no estudo.

Nos capítulo 6, 7 e 8 são apresentados, respectivamente, a análise dos resultados, as conclusões e as referências bibliográficas utilizadas neste trabalho. 


\section{Capítulo 2}

\section{Objetivos}

\subsection{Propósito da pesquisa}

O propósito desta pesquisa é analisar algumas características da gestão de projetos complexos e incertos em empresas no Brasil, que permitam entender porque e como uma abordagem contingencial estruturada de gestão de projetos pode potencializar, de alguma maneira, as chances de sucesso desses projetos.

Como esse é um propósito muito abrangente e vago, a seguir são estabelecidos os objetivos específicos através da descrição das questões de pesquisa e dos resultados esperados.

\subsection{Questões de pesquisa}

- Como são definidos e geridos os projetos complexos e incertos em empresas que atuam no Brasil?

- Como os aspectos observados de definição e gestão contribuem para o sucesso ou fracasso dos projetos?

\subsection{Resultados esperados da pesquisa}

- Descrição da dinâmica de gestão de projetos complexos e incertos nas empresas estudadas.

- Análise da contribuição das abordagens de gestão para o sucesso ou fracasso dos projetos.

- Entendimento, crítica e melhorias do modelo de abordagem contingencial apresentado por Shenhar e Dvir (2007) no contexto de empresas que atuam no Brasil. 
A inter-relação entre as questões de pesquisa e os resultados esperados é mostrada na figura 1 .

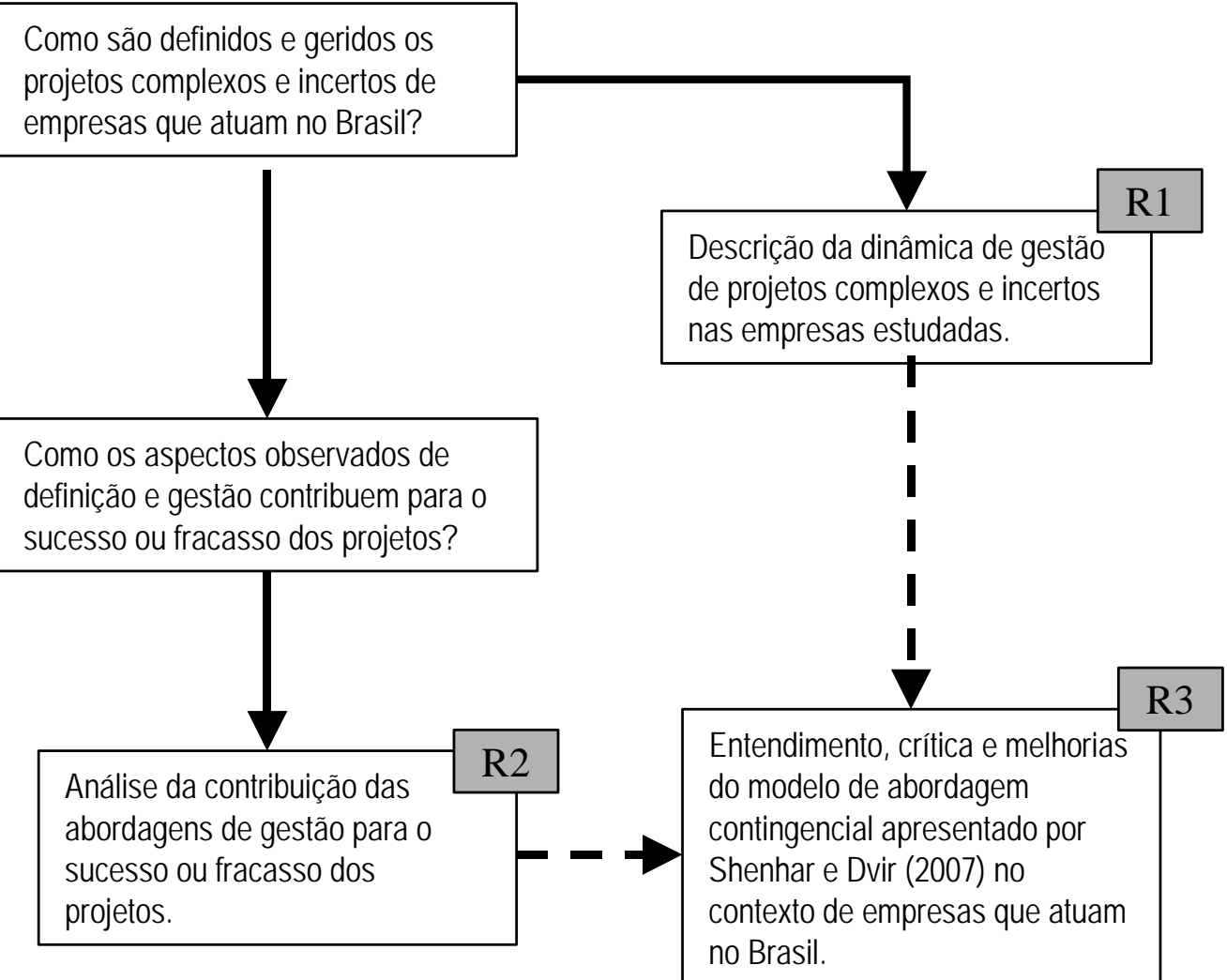

Figura 1 - Relações entre questões e resultados da pesquisa 


\subsection{Justificativa da pesquisa}

Este trabalho começou a ser desenhado a partir da conjunção de dois fatores que despertaram a curiosidade do autor. Primeiro, a constatação do alto índice de insucessos dos projetos, evidenciada pela análise da literatura, por observações tiradas da experiência profissional de 20 anos do autor em gestão de projetos, por relatos de alunos nos cursos de gestão de projetos nos quais o autor é docente e por relatos de clientes em projetos de consultoria. Segundo, a observação do crescente interesse de praticantes e acadêmicos nas abordagens contingenciais de gestão de projetos.

Além da curiosidade do autor, este trabalho também é justificado pela contribuição acadêmica e pela oportunidade de abordagem.

O tema tem sido discutido nos meios acadêmicos e profissionais, com surgimento de proposições e modelos de abordagens adaptativas ou contingenciais para a gestão de projetos, tratando-se portanto, de um tema atual e de interesse para pesquisadores e praticantes da gestão de projetos. Particularmente, o modelo de abordagem contingencial de Shenhar e Dvir (2007), escolhido como referencial teórico da pesquisa, teve forte repercussão entre praticantes e acadêmicos desde seu lançamento.

Este trabalho é inédito por conta de dois fatores. Primeiro, os estudos sobre abordagens contingenciais de gestão de projetos tem uma pequena base empírica. Este trabalho é sustentado em dados empíricos obtidos através de múltiplos casos. Segundo, não foi encontrado nenhum trabalho referente ao entendimento e aplicação do modelo de abordagem contingencial de Shenhar e Dvir (2007) dentro do universo de projetos complexos e incertos de empresas que atuam no Brasil.

A oportunidade de abordagem refere-se ao atual momento da economia brasileira. O fenômeno de internacionalização das economias dos países trouxe várias transformações para as empresas que atuam no Brasil. O nível de concorrência aumentou em vários setores, o que trouxe maior pressão por mudanças. Essas mudanças acabam gerando uma quantidade maior de 
projetos complexos e incertos que precisam ser implantados com sucesso para garantir a sobrevivência e prosperidade das empresas.

Nesse contexto de maior quantidade de projetos complexos e incertos e do grande número de insucessos, a discussão de abordagens gerenciais que potencialmente podem aumentar as chances de sucesso dos projetos está em sintonia com as necessidades atuais das empresas no Brasil. 


\section{Capítulo 3}

\section{Fundamentos teóricos}

\subsection{Importância e desempenho dos projetos nas organizações}

Com a alta demanda por crescimento e inovação, os projetos passaram a ter importância cada vez maior nas organizações. De acordo com Shenhar e Dir (2007), a globalização dos mercados força as empresas a responderem demandas locais e a competirem por baixo custo no mundo todo. Da mesma forma, as tecnologias da informação e da Internet provocaram uma revolução de mudanças nas empresas que continuam em curso. Os projetos são iniciativas únicas, como lançar novos produtos, novas organizações ou novos empreendimentos, ou ainda, melhorar produtos existentes e investir na infraestrutura da empresa. Para Cleland (1994), projetos são os elementos executores de mudanças que permitem às organizações sobreviver e crescer.

Evidentemente, neste cenário de crescente participação dos projetos, a gestão de projetos tornou-se uma competência que pode trazer vantagens competitivas para as organizações. Segundo Kerzner (2000), muitas organizações perceberam a possibilidade de usar a gestão de projetos como uma arma competitiva para alavancar seus negócios através de maior qualidade e valor adicionado para o cliente ou consumidor. Nesta lista estão incluídas empresas como a 3M, GE, HP, IBM, Nortel, entre outras. A percepção da gestão de projetos como diferencial também pode ser observada entre os praticantes. Por exemplo, o número de membros associados ao Project Management Institute -PMI entre 1993 e 2007, saltou de aproximadamente 10.000 para 200.000 , indicando uma grande procura por conhecimentos e referências para a gestão de projetos (PMI, 2007).

Apesar da importância cada vez maior dos projetos nas organizações, a maioria dos projetos não atende suas metas iniciais. Marques Jr (2000) 
aponta atrasos médios de 103\% numa pesquisa com 398 projetos de construção no setor público. Pesquisa da KPMG (2002) mostra que 61\% dos projetos de TI fracassaram em uma amostra de 176 empresas públicas e privadas do Canadá. O Chaos Report (1995) aponta que 31.1\% dos projetos de tecnologia da informação foram cancelados antes de terminarem. Outro número do mesmo relatório mostra que $52.7 \%$ dos projetos tiveram aumento médio de 189\% nos custos. Shenhar e Dvir (2007) pesquisaram 600 projetos nos setores privado, governamental e terceiro setor em vários países e constataram que $85 \%$ dos projetos não atingiram o prazo e orçamento originais, com atraso médio de $70 \%$ e aumento médio de $60 \%$ no orçamento.

As causas apontadas para o não atendimento das metas dos projetos são diversas. Marques Jr (2000) aponta os fatores ligados ao planejamento como a causa mais freqüente dos problemas nos projetos de construção na área pública. Hartman e Ashrafi (2002) definem causas críticas: falta de definição do que seja sucesso, falta de apoio da alta administração, falta de métricas para controle e falta de alinhamento dos interessados com critérios de sucesso. Na pesquisa KPMG (2002), as causas são o planejamento deficiente, a falta de alinhamento com o negócio e a falta de envolvimento da alta administração. Black (1996), em pesquisa com 70 engenheiros, aponta a falta de definição no início do projeto como a causa principal de atrasos e custos acima do orçamento. Em projetos de web design, Fichter (2003), relaciona as principais causas de problemas: falta de envolvimento do usuário, falta de apoio dos executivos da empresa, falta de definição clara dos requisitos e planejamento.

Historicamente, o combate a essas causas tem foco no desenvolvimento e aperfeiçoamento de ferramentas e técnicas de planejamento e controle.

Morris (1994) faz um histórico do desenvolvimento da gestão de projetos que evidencia o enfoque no planejamento e controle. Entre 1955 e 1970 houve um explosivo desenvolvimento de ferramentas e conceitos de planejamento e controle de projetos nos setores de defesa e aeroespacial. Deste período vieram as técnicas Critical Path Method - CPM, Program Evaluation and Review Technique - PERT, Cost/Schedule Control Systems Criteria C/SCSC, Graphical Evaluation and Review Technique - GERT. Na década 
de 1970, o foco acadêmico ficou direcionado para projetos de engenharia e construção e parecia reforçar a visão de que gestão de projetos era a aplicação de ferramentas e técnicas para construir e desenvolver. Na década de 1980 houve um aumento substancial na quantidade de artigos sobre gestão de projetos, mas o enfoque continuou sobre ferramentas e técnicas, deixando em segundo plano as questões estratégicas que afetam o sucesso do projeto. Nas palavras de Morris (1994):

“...embora o assunto gestão de projetos esteja comparativamente maduro, e reconhecido por milhares ou milhões de gerentes como de vital importância, em muitos aspectos ela (a gestão de projetos) parece ter parado no tempo, na década de 1960."

Segundo Packendorff (1995), o histórico das pesquisas em gestão de projetos mostra que o núcleo base da gestão de projetos foca o planejamento e o controle. A gestão de projetos pode ser descrita em termos de teorias de planejamento, controle e avaliação, mas a cobertura de pesquisas e análises é concentrada sobre planejamento e controle, com pouca ênfase na avaliação. A premissa básica deste enfoque é que as atividades de projeto são claramente definidas, sem ambigüidade. Desta forma, os esforços do gerente de projeto deveriam ser dedicados para o uso eficiente dos recursos e técnicas para a gestão do projeto.

Thomitocleos e Wearne (2000) fizeram uma revisão sobre tópicos cobertos em artigos publicados no International Journal of Project Management de 1984 a 1998 e no Project Management Journal de 1990 a 1998 e constataram que tópicos relacionados ao planejamento, monitoramento, controle, análise de risco, aquisições e contratos receberam muito mais atenção comparativamente a outros tópicos, como início e término de projetos.

Segundo Thomas (2000), a maioria das contribuições acadêmicas para a gestão de projetos focam o desenvolvimento de modelos de planejamento. A partir desta base inicial, pesquisas posteriores buscaram desenvolver conceitos como planejamento do ciclo de vida, análise de riscos e avaliação 
de valor dos projetos. As técnicas mais usadas eram: a estrutura analítica do projeto, o gráfico de Gantt, o método CPM, o PERT e o GERT. A conclusão de Thomas (2000), após revisão da bibliografia, é que as pesquisas sobre gestão de projetos tendem a ser não empíricas e dominadas por entendimentos mecanicistas das organizações e projetos. Na maioria dos casos, as pesquisas se baseiam na idéia de que deveria existir uma teoria geral sobre gestão de projetos e cada projeto deveria ser gerido segundo esta teoria.

Kloppenborg \& Opfer (2002) lideraram um estudo feito sobre quarenta anos de pesquisa em gestão de projetos (de 1960 a 1999), no qual é constatado que $52 \%$ dos artigos publicados nas fontes selecionadas são sobre planejamento e controle. Segundo este mesmo estudo, o foco em planejamento e controle foi mais intenso até o final da década de 1970 , quando começou a aumentar o número de artigos sobre liderança e gestão de conflitos. Nos anos 1980, o foco ainda continuou sobre planejamento e controle, com alguns artigos sobre desenvolvimento de equipes e gestão de qualidade. Na década de 1990, o estudo observou um grande crescimento da quantidade de projetos de pesquisa sobre montagem de equipes, liderança e motivação.

Leybourne (2007) faz uma revisão da evolução da pesquisa em gestão de projetos, iniciando no pós segunda grande guerra, com o desenvolvimento de técnicas de programação e controle para os grandes projetos na área militar. Vem daí o PERT, o Earned Value Management System - EVMS e o Work Breakdown Structure - WBS. Na década de 1970, o foco acadêmico ficou direcionado para projetos de engenharia e construção e parecia reforçar a visão de que gestão de projetos era a aplicação de ferramentas e técnicas para construir e desenvolver, não para mudar. Nos anos 1980 novos tópicos buscavam novos enfoques, como critérios de sucesso dos projetos. Essa tendência se ampliou na década de 1990 e 2000, com trabalhos em desenvolvimento de equipes, liderança, passando para gestão de conhecimento. Os focos de pesquisa eram sobre sucesso nos projetos, como evitar fracassos, e a criação de tipologias para projetos. 
Uma percepção é que as pesquisas feitas sobre a gestão de projetos tradicionais lidam com técnicas e procedimentos invés de práticas gerenciais. Neste sentido a gestão de projetos pode ser percebida como positivista, tecnocentrada e racional. Predominam as teorias normativas, nas quais a premissa é que aplicar corretamente um conjunto de procedimentos, técnicas e ferramentas aumenta as chances de sucesso dos projetos.

O enfoque normativo é a base da abordagem tradicional ou convencional de gestão de projetos. Esta abordagem é descrita a seguir.

\subsection{Abordagem tradicional de gestão de projetos}

A abordagem tradicional de gestão de projetos descreve os processos de planejamento, organização, direcionamento e controle da equipe para atender metas e objetivos estabelecidos (CLELAND, 1994). A premissa fundamental é que um projeto tem uma tarefa definida e que portanto, os esforços do gerente de projeto e de sua equipe podem ser dirigidos para o uso eficiente de recursos e técnicas (PACKENDORFF, 1995).

A abordagem tradicional pode ser observada na descrição que Cleland (1994) sugere para os passos de uma programação de projetos:

1. Definir os objetivos, metas e estratégias gerais do projeto.

2. Desenvolver o WBS.

3. Seqüenciar os pacotes de trabalho e atividades.

4. Estimar os elementos de tempo e custo.

5. Revisar a programação máster em face das restrições de tempo do projeto.

6. Reconciliar a programação com as restrições de recursos organizacionais.

7. Revisar a consistência da programação em relação aos objetivos de custo e de desempenho técnico do projeto.

8. Aprovar a programação junto à gerência sênior. 
Para Packendorff (1995), partindo da premissa de que as tarefas do projeto são dadas, a gestão de projetos convencional recomenda a construção da WBS, seguido pela busca da seqüência ótima de atividades e pela alocação dos recursos corretamente. O projeto é visto como um todo, constituído de suas partes e das interdependências entre elas. Quanto melhor a estruturação das partes, melhor o todo.

Segundo Shenhar e Dvir (2007) a abordagem tradicional começa com a criação de uma declaração de escopo, que define o trabalho que precisa ser feito, com os principais produtos/serviços a serem entregues. Este escopo é decomposto em pacotes de trabalho, organizados hierarquicamente numa WBS. Em conjunto com a WBS é construída a Organizational Breakdown Structure - OBS. A partir daí é montada a rede de atividades do projeto, sobre a qual são alocados os recursos necessários, finalizando com a montagem do cronograma do projeto. Outros elementos do plano do projeto são então agregados. O objetivo do controle dos projetos é garantir a realização do projeto dentro do prazo, dentro do orçamento, e de acordo com as especificações.

A abordagem tradicional é caracterizada pelo racionalismo e pelo positivismo. O racionalismo vem da premissa implícita de que a abordagem tradicional é correta e deve servir como referência para gerir projetos com sucesso. Segundo Packendorff (1995), a maior parte dos livros-texto de gestão de projetos contém recomendações normativas sobre como planejar e controlar os projetos. A experiência profissional dos autores dos livros-texto, usada para aumentar a credibilidade de seus relatos, são raramente usadas para ilustrar modelos normativos. Os casos relatados na literatura são exemplos de sucesso, que mostram os benefícios de se usar técnicas e ferramentas, ou são exemplos de fracassos imputados ao uso incorreto ou ao não uso das técnicas e ferramentas de planejamento e controle. O surgimento dos softwares no início da década de 1980 e o seu crescente desenvolvimento, com preços acessíveis e sofisticação, permitiram aos praticantes da gestão de projetos aplicar as técnicas de planejamento numa ampla escala de projetos. 
O posicionamento positivista pressupõe que a realidade existe e pode ser observada, permitindo assim definir uma referência de melhores práticas. Segundo Smyth \& Morris (2007), em pesquisa feita em artigos publicados no ano de 2005 no International Journal of Project Management, o positivismo tem sido dominante nas pesquisas sobre gestão de projetos. O positivismo busca a generalização para estabelecer princípios ou leis que regem um fenômeno.

Na década de 1990, o surgimento e disseminação dos documentos de orientação de boas práticas, conhecidos como Body of Knowledge (Bok) em gestão de projetos contribuíram para renovar o foco no planejamento e controle dos projetos e reforçar a visão normativa e prescritiva da gestão de projetos, caracterizada pela premissa implícita de que basta seguir as melhores práticas que os projetos terão sucesso (PACKENDORFF, 1995; WILLIAMS, 2005). Segundo o PMBOK (2004), o sistema de gestão de projetos é formado por processos associados a nove áreas de conhecimento que o gerente de projetos deve dominar para, em conjunto com aspectos comportamentais (liderança, comunicação interpessoal, gestão de conflitos, etc.), atender as metas do projeto. Os grupos de processos são: iniciação, planejamento, execução, controle e encerramento. As áreas de conhecimento são: gestão da integração, gestão do escopo, gestão do tempo, gestão dos recursos humanos, gestão de custos, gestão das aquisições, gestão da qualidade, gestão do risco, gestão da comunicação. O PMBOK (2004) é normativo e positivista, pois pretende servir de referência de melhores práticas na gestão de projetos.

O paradigma da abordagem tradicional é de ordenação num ambiente previsível, porém tem sido levantadas dúvidas sobre a validade deste paradigma e das premissas implícitas para a gestão efetiva dos projetos. A seguir são levantados os pontos de questionamento sobre a abordagem tradicional.

As críticas à abordagem tradicional de gestão de projetos são concentradas em sua inadequação para gestão de projetos complexos e incertos nas organizações. Esta inadequação vem dos enfoques racionalista e normativo da abordagem tradicional que apregoam que o sucesso do projeto vem da 
aplicação de melhores práticas normatizadas. A visão tradicional de gestão de projetos adota uma abordagem mecanicista. A lógica reside na idéia de que deveria existir uma teoria geral de gestão de projetos e todos os projetos deveriam ser geridos de acordo com essa teoria. A premissa implícita é que os procedimentos para planejar, controlar e conduzir projetos são os mesmos independentemente da natureza dos projetos.

No entanto, pesquisas tem mostrado resultados contraditórios: os planos de projeto não são estáveis; os procedimentos de planejamento servem mais para legitimar o projeto do que guiá-lo; ferramentas sofisticadas de planejamento raramente são usadas; planos precisos nem sempre são as ferramentas gerenciais mais úteis.

Packendorff (1995) critica os enfoques da abordagem tradicional em três pontos. O primeiro ponto é a premissa geral de que o conhecimento de gestão de projetos é padronizável e aplicável a todos os tipos de projetos em diferentes setores e ambientes. Segundo o autor, a gestão de projetos é diferente para diferentes projetos e essas diferenças afetam o perfil de competência do gerente de projetos, a montagem da equipe, a escolha dos métodos de planejamento e os critérios de avaliação utilizados. Reconhecer a necessidade de diferentes teorias para diferentes tipos de projetos poderia ser um caminho a ser perseguido para descrever melhor os projetos. $\mathrm{O}$ segundo ponto é a falta de pesquisa empírica descritiva fundeada em problemas teóricos. O foco é normativo, com projetos bem sucedidos por causa da correta aplicação das normas e com projetos fracassados por causa da falta ou da incorreta aplicação das normas. O terceiro ponto é a visão dos projetos como ferramentas, e não como organizações. Ainda segundo o autor, parece existir uma ânsia de pesquisadores e praticantes em fornecer respostas diretas, modelos elegantes e verdades universais. No entanto, conforme foi visto anteriormente neste trabalho, os projetos continuam a ter altos índices de fracasso.

Kreiner (1995) levanta a questão da relevância dos resultados programados originalmente para os projetos no decorrer do tempo de implantação dos mesmos. A relevância pode ser alterada se o ambiente do projeto mudar, como por exemplo através de uma mudança de preferência dos 
consumidores ou de uma mudança de estratégia dos competidores. Nestas situações a efetividade da abordagem tradicional, centrada na racionalização, é questionada, dado seu potencial para interferir no sucesso do projeto. Segundo o autor, essa interferência ocorre porque as melhores práticas de gestão de projetos, conhecidas como Body of Knowledge - BOK, instruem o gerente de projetos a minimizar os riscos de metas ambíguas e implementações ineficientes. A questão da relevância dos resultados a serem gerados pelo projeto é analisada por outras pessoas.

Maylor (2001) considera que muitas questões relevantes não recebem o tratamento adequado na abordagem tradicional de gestão de projetos e que isto não se encaixa com o contexto no qual os gerentes de projetos operam atualmente em muito setores. A abordagem tradicional de gestão de projetos é baseada em modelos determinísticos desenvolvidos na década de 1950 que, apesar dos refinamentos, não é utilizada por muitas organizações de classe mundial. Por exemplo, a gestão de projetos de desenvolvimento de produtos na indústria automobilística japonesa não utiliza os métodos e abordagens tradicionais de gestão de projetos. Empresas como HP e Motorola também tem abordagens para gestão de projetos não aderentes à abordagem tradicional.

Mills et al (2002) argumentam que as ferramentas tradicionais de gestão de projetos são irrelevantes para a gestão de projetos de inovação tecnológica. Eles apresentam um estudo de práticas em projetos de inovação de quatro empresas compradoras de Pesquisa e Desenvolvimento - P\&D, três provedores de P\&D e seis empresas de sucesso da Nova Zelândia dos setores de eletrônicos, alimentos e florestal. O texto faz referência a uma pesquisa anterior feita por Mills (Mills, 1996), em que somente um de vinte e cinco gerentes de projetos de inovação estavam satisfeitos com as práticas correntes de gestão de projetos em suas empresas.

Midler (2002) considera o paradigma tradicional de gestão de projetos como motivado por demandas. Profissionais são organizados para responder uma demanda explícita do cliente. No cenário de competição através de inovações, a percepção é que o processo é motivado pelo design e não pelo mercado. Inovações como Walkman da Sony, Post-it da 3M ou Navigator da 
Netscape não foram desenhados para responder uma questão específica de clientes atuais. Neste contexto, onde as estratégias de inovação são mais proativas do que reativas ao mercado, a implantação do modelo tradicional de gestão de projetos é problemática.

Muriithi e Crawford (2003) investigaram a aplicabilidade e relevância da abordagem tradicional de gestão em projetos no Quênia. A constatação deles foi que as bases de racionalidade e eficiência dominantes nas técnicas e ferramentas de gestão de projetos não refletem as realidades locais. Por essa razão, o uso dessas técnicas não aumenta a chance de sucesso dos projetos.

Jaafari (2003) argumenta que a abordagem convencional de gestão de projetos é baseada num paradigma de ordenação num ambiente previsível. Este paradigma precisa ser mudado para tornar a gestão de projetos relevante e efetiva em uma sociedade complexa.

Cicmil (2006) afirma que a maioria dos livros e das associações de gestão de projetos promovem a visão normativa do campo como prática, que pode ser sintetizada como a aplicação de conhecimento, habilidades, ferramentas e técnicas às atividades do projeto para atender os requisitos do projeto.

Williams (2005) considera que os métodos convencionais de gestão de projetos são inadequados para projetos complexos, incertos e limitados por tempo. O atual discurso sobre gestão de projetos, baseado em três ênfases: planejamento, controle cibernético e descolamento do ambiente leva aos fracassos. Trabalhos empíricos de modelagem sistêmica de gestão de projetos trazem explicações para os atrasos dos projetos. No entanto, estas explicações não são incorporadas à gestão dos projetos pois entram em choque com o racionalismo e positivismo do discurso atual. $\mathrm{O}$ argumento do autor é que algumas ações gerenciais recomendadas pela abordagem tradicional quando o projeto tem problema potencializam os ciclos viciosos. Além disso, fatores soft podem estar na raiz do escalonamento dos círculos viciosos, como moral da equipe e stress no trabalho. Mais especificamente, o modelo sistêmico tem conflitos com premissas embutidas no modelo tradicional de gestão de projetos: 
- O modelo sistêmico mostra interações complexas entre várias partes do projeto que levam a comportamentos não previstos dos projetos. Isto mostra que a premissa de decomposição do trabalho em alguns casos pode ser inadequada.

- Os feedbacks podem ser exacerbados por ações gerenciais recomendadas pelas abordagens tradicionais, desafiando a premissa de que a gestão de projetos tradicional é inerentemente correta.

- Os aspectos soft são ligações importantes nas cadeias de causalidade dos círculos de feedback; modelos devem incorporar dados reais e percepções, construindo socialmente a realidade em um projeto, desafiando a premissa positivista da gestão de projetos tradicional.

Williams (2005) conclui apontando três razões para os altos índices de fracasso dos projetos:

- Negligência da abordagem tradicional em relação a visão sistêmica necessária pela complexidade dos projetos que podem se comportar de maneira imprevisível.

- Projetos com grande incerteza não combinam com a visão cartesiana da abordagem tradicional. As metas do projeto são incertas.

- Métodos convencionais se baseiam no princípio de "gerenciar conforme planejado".

Hallgreen et al (2005) apresentam um estudo de caso de um projeto de automação onde é investigada a maneira como os desvios são gerenciados. O resultado apontou que as ferramentas e métodos sugeridos na literatura são raramente usados e mostrou a importância do contexto do projeto em termos de reunião de informações e compartilhamento de conhecimento para gerenciar tais desvios.

Cicmil (2006) argumenta que a crítica à abordagem tradicional foca na meta funcionalista/positivista de disseminar melhores práticas em gestão de projeto para praticantes, com a crença implícita na possibilidade de racionalização e generalização dos Boks. A prescrição de melhores práticas sugere que a sua 
correta aplicação pode aumentar as chances de sucesso em uma ampla gama de diferentes projetos.

Leybourne (2007) afirma que deveria existir dúvida da aplicação do paradigma positivista, baseado em regras e certezas, ao cenário dos projetos, envolvendo ações únicas tomadas em um ambiente incerto e turbulento. A visão de que o uso de técnicas e ferramentas de gestão de projetos podem melhorar o processo de implementação estratégica parece estar sendo questionada desde a virada do milênio. Isso parece não ser suficiente, dado que os altos índices de insucessos dos projetos permanecem.

Shenhar e Dvir (2007) argumentam que o sistema de gestão de projetos é baseado em um modelo previsível, fixo, relativamente simples e certo, e portanto, desassociado de mudanças no ambiente ou na necessidade do negócio. Os autores argumentam que os projetos fracassam por não usarem o estilo gerencial mais adequado às suas características de complexidade e incerteza. Os autores consideram que as causas mais citadas para os fracassos dos projetos não são suficientes para explicar o fenômeno. Planejamento ruim, falta de comunicação e recursos inadequados não explicam porque projetos que atingiram as metas de prazo, custo, qualidade também fracassaram.

Hartman (2008) argumenta que nas últimas duas décadas, a gestão de projetos foi reduzida para uma abordagem prescritiva, com ferramentas, processos e técnicas que reforçam ainda mais esta abordagem. Segundo o autor, esta visão prescritiva não atende as necessidades gerenciais do projeto.

Estas críticas desencadearam a busca de novas abordagens para adaptar a gestão às condições de incerteza e complexidade associadas às metas, atividades e ao ambiente no qual os projetos estão inseridos. O foco destas novas abordagens é uma gestão contingencial dos projetos. 


\subsection{Abordagem contingencial de gestão de projetos}

As abordagens alternativas para a gestão de projetos surgiram no final dos anos 1980 e início dos anos 1990 como resposta direta ao reconhecimento das fraquezas do poder do modelo explanatório tradicional.

A origem da gestão contingencial vem da observação que um projeto está submetido a influências desconhecidas que podem surgir da ambigüidade e da complexidade do projeto. Ambigüidade se refere a falta de consciência da equipe do projeto sobre certos eventos ou seus efeitos. Complexidade significa que muitas ações diferentes e parâmetros de eventos interagem, o que torna difícil avaliar o efeito dessas ações (PICH et al, 2002).

A ambigüidade e a complexidade dos projetos traz implicações para a gestão de projetos. Por exemplo, a necessidade de ciclos de iterações, com designs e testes em projetos de desenvolvimento de produtos, sendo tais iterações muito importantes em ambientes que exigem tempos curtos de lançamento do produto no mercado (EISENHARDT \& TABRIZI, 1995). Portanto, constatase que os projetos não são fundamentalmente iguais e que existe a necessidade de identificar características importantes para uso mais apropriado de técnicas e ferramentas de gestão de projetos (PINTO \& SLEVIN, 1988).

As abordagens contingenciais serão examinadas conforme suas premissas: (1) os projetos se diferenciam de acordo com vários critérios; (2) as práticas de gestão de projetos deveriam variar com o tipo de projeto; (3) os critérios de sucesso dos projetos deveriam variar conforme o tipo de projeto.

A seguir estes aspectos são revisados em maior profundidade.

\subsubsection{Classificação dos projetos}

A necessidade de identificar características importantes dos projetos levou ao surgimento de proposições para a classificação dos projetos. Packendorff (1995) sugere que os projetos devem ser classificados de acordo com o nível de dependência da organização permanente para a realização dos projetos. Assim temos: força-tarefa pura, matriz funcional, grupo de ação e renovação interna. 
Westerveld (2003) sugere dividir os projetos de acordo com a complexidade do escopo, avaliado de acordo com a quantidade de interessados e a quantidade de interações entre eles. A classificação sugerida por Westerveld (2003) é a seguinte:

- Orientado pelo produto: trata-se de um projeto com escopo simples. Por exemplo um trabalho simples de troca de algumas telhas num telhado executado por uma pessoa da equipe de manutenção.

- Orientado pela ferramenta: trata-se de um projeto com escopo mais complexo que utilize uma metodologia com ferramentas e técnicas e tenha a participação de terceiros. Por exemplo uma parada de manutenção de máquinas de um setor fabril executada por um agente externo.

- Orientado pelo sistema: um projeto nesta categoria é um sistema constituído por contratados e uma organização de projeto definida para entregar um conjunto de produtos onde as demandas dos usuários e partes interessadas são levadas em conta. Por exemplo, a construção de uma escola, onde as demandas da comunidade local, dos professores e dos alunos são ouvidas. A organização do projeto então pode projetar e implantar a nova escola.

- Orientado pela estratégia: um projeto nesta categoria é uma organização de partes diretamente envolvidas para atender uma necessidade de um cliente e usuários dentro dos limites definido pelas partes interessadas externas. Por exemplo, a implantação de um novo sistema de gestão integrada numa empresa.

- Gestão de projetos total: um projeto nesta categoria é uma rede complexa de partes interessadas tentando atender a necessidade de um cliente e usuário. Por exemplo, um projeto de remodelação urbana que envolva a interação de cidadãos, lojistas, órgão públicos, projetistas e construtoras para executar o projeto.

Shenhar e Dvir (2007) sugerem classificar o projeto conforme o posicionamento em quatro dimensões: inovação, tecnologia, complexidade e ritmo. 
- Inovação: representa a incerteza da meta do projeto e/ou a incerteza no mercado.

- Tecnologia: representa a incerteza tecnológica.

- Complexidade: mede a complexidade do produto, tarefa, e organização.

- Ritmo: representa a urgência do projeto.

Cada uma dessas dimensões é dividida em graduações. A dimensão inovação é subdividida em derivativo, plataforma e ruptura. A dimensão da incerteza da tecnologia a ser empregada no projeto é subdividida em baixa, média, alta e super alta tecnologia. A dimensão complexidade é subdividida em montagem, sistema e grande sistema. Por fim, a dimensão ritmo é subdividida em regular, competitivo, crítico e blitz.

Donk e Molloy (2008) sugerem uma tipologia de projetos:

- Projetos simples: mecanismo de coordenação de supervisão direta, com um líder de projeto. Ex: eventos, viagens, concertos

- Projeto burocrático: padronização de processos de trabalho, com planejadores, compradores, engenheiros (estrutura técnica). Ex: construção

- Projeto por divisão: padronização de habilidades, com equipes de projeto profissionais e especialistas (base operacional). Ex: P\&D, desenvolvimento de novos produtos

- Projeto profissional: padronização de saídas (resultados) com gerentes de conta (média gerência). Ex: consultores, agências de propaganda, projetos tipo Enterprise Resource Planning - ERP.

- Adhocracia: ajustamento mútuo, com equipe de suporte. Ex: grandes projetos inovativos.

\subsubsection{Adaptação da gestão do projeto}

A conseqüência destas novas tipologias é que projetos de naturezas diferentes exigem práticas diferentes das contidas na gestão de projetos tradicional ou exigem adaptação das práticas tradicionais. 
Morris (1994) sugere três diferentes níveis de entendimento da gestão de projetos. No nível básico, a gestão de projetos é uma integradora do que precisa ser feito para que os objetivos sejam atingidos (planejamento, organização, controle, etc). No segundo nível, existem tarefas adicionais de maior complexidade, além das atividades do nível básico (definição do projeto, contratação, planejamento, medição e liderança). No terceiro nível a complexidade aumenta. A gestão de projetos inclui aspectos estratégicos da definição do projeto, políticas, estratégia, tecnologia, legal, financeiro, ambiental, comunidade e outros. Neste nível a gestão de projetos não está focada simplesmente nas atividades, mas também no ambiente no qual as atividades serão realizadas.

Pich et al (2002) propõem um modelo para escolha da abordagem mais adequada para gerir um projeto entre três opções possíveis: instrucionismo, aprendizado e selecionismo. Os autores consideram que os métodos clássicos de gestão de projetos são instrucionistas, ou seja, os objetivos estão claros e basta seguir um conjunto prescritivo de procedimentos para realizar o projeto com sucesso. As abordagens de aprendizado e selecionismo são recomendadas quando o ambiente muda muito ou é muito incerto. Nestas abordagens o modelo de gestão disponível não é adequado para a equipe definir suas estratégias. Isso significa que existem fatores da realidade não representados no modelo e que esses fatores tem influência significativa nos resultados do projeto.

Esses fatores da realidade não representados no modelo são desconhecidos e podem surgir da ambigüidade e da complexidade do projeto. Ambigüidade se refere à falta de conhecimento da equipe do projeto sobre fatores da realidade ou relações causais. A complexidade significa que diferentes ações e fatores interagem , tornando difícil avaliar os efeitos das ações.

Mills et al (2002) propõe um modelo de gestão de projetos de inovação para acomodar a necessidade de alinhamento dos projetos individuais com os objetivos de negócio num cenário de incerteza e rápidas mudanças de ambiente. 
Jaafari (2003) usa a complexidade ambiental e a capacidade dos gerentes de projeto em reduzir a complexidade para definir quatro abordagens: (1) modelo adhoc; (2) modelo burocrático; (3) modelo normativo; (4) modelo criativo-reflexivo. Segundo o autor, esta categorização permite identificar se os modelos contemporâneos de gestão de projetos são capazes de responder a uma sociedade complexa, e também se as abordagens de desenvolvimento profissional de gerentes de projeto refletem as dinâmicas da sociedade complexa.

Shenhar e Dvir (2007) propõe um modelo adaptativo para gestão de projetos nas organizações. A nova abordagem é focada em um modelo direcionado para o sucesso, que tenha flexibilidade e seja adaptativo. Os projetos passam de um conjunto de atividades a serem entregues no prazo e no custo para processos relacionados a negócios que devem entregar resultados de negócio. A intenção do modelo é disciplinar a análise de benefícios e riscos esperados de um projeto e desenvolver um conjunto de regras e comportamentos para cada tipo de projeto. Segundo os autores, o modelo proposto pode ajudar a atacar a causa raiz dos fracassos dos projetos. Em pesquisas realizadas por eles ao longo de 15 anos em cerca de 600 projetos foi observado que os executivos e equipes de projetos falham na avaliação inicial das incertezas e complexidades dos projeto e/ou comunicação dos resultados dessas análises e falham também na adaptação dos estilos gerenciais à situação.

No modelo de classificação dos projetos sugerido por Shenhar e Dvir (2007), o posicionamento do projeto em cada uma das dimensões propostas (inovação, tecnologia, complexidade e ritmo) tem impactos na gestão do projeto. Quanto mais próximo do extremo, as implicações na gestão de projetos se tornam mais acentuadas. São sugeridas as seguintes implicações para a gestão de projetos nas dimensões de inovação, tecnologia, complexidade e ritmo.

Na dimensão de inovação, quanto mais próximo do posicionamento extremo (ruptura), maior o tempo necessário para congelamento de especificações do produto e para precisão e confiabilidade dos dados de mercado. No nível de 
ruptura é preciso obter feedback rápido dos consumidores usando protótipos antecipados antes de definir os requisitos do produto.

$\mathrm{Na}$ dimensão de incerteza da tecnologia, quanto mais próximo do posicionamento extremo (super alta tecnologia), maior o tempo para conseguir o design correto e congelá-lo, maior a intensidade de atividades técnicas e mais importante se tornam as competências técnicas requeridas da equipe do projeto.

$\mathrm{Na}$ dimensão de complexidade, quanto mais próximo do posicionamento extremo (grandes sistemas), maior o efeito sobre a organização do projeto, com maior nível de burocracia e formalidade.

$\mathrm{Na}$ dimensão do ritmo, quanto mais próximo do posicionamento extremo (blitz), maior o efeito sobre o planejamento e suas atualizações, maior necessidade de autonomia da equipe e maior necessidade do envolvimento dos executivos.

Donk e Molloy (2008) comentam sobre as implicações gerenciais que surgem do entendimento das diferenças entre os projetos. Gerentes de projeto, patrocinadores e proprietários podem ter a oportunidade de comparar formas de organização mais adequadas com as práticas correntes de organização. Outra implicação é a observação não intuitiva de que muitos projetos falham por causa do excesso de controle, sugerindo cuidado especial na escolha do melhor tipo de organização de projetos.

\subsubsection{Critérios de sucesso dos projetos}

O significado de sucesso de um projeto não é consenso entre os praticantes. Por um lado existem projetos que foram entregues no prazo, atenderam o custo e os requisitos de desempenho, mas que foram considerados fracassos. Por exemplo, o projeto do serviço de telefonia via satélite Iridium, lançado na década de 1990 foi considerado um "sucesso" ao término de sua implantação, pois atendeu o prazo e o orçamento originais. No entanto, hoje o projeto Iridium é considerado um fracasso, pois o negócio não prosperou conforme esperado (PINTO \& SLEVIN, 1988; SHENHAR \& DVIR, 2007).

Por outro lado, existem projetos que não cumpriram o prazo, não atenderam o custo e os requisitos de desempenho, mas são considerados exemplos de 
sucesso. Por exemplo, o anfiteatro de Sydney na Austrália foi planejado originalmente para estar pronto em cinco anos e consumir um orçamento de sete milhões de dólares australianos. Ao final, o projeto levou 16 anos e consumiu 100 milhões de dólares australianos. No entanto, hoje o projeto é considerado um sucesso (PINTO \& SLEVIN, 1988; SHENHAR \& DVIR, 2007).

Pinto e Slevin (1988) sugerem um modelo para definição dos critérios de sucesso de um projeto baseado em duas dimensões iniciais, projeto e cliente, que representam aspectos internos e externos aos projetos. Cada uma destas dimensões é então subdividida em outros critérios:

- Projeto:
o Tempo: atender o prazo
o Custo: ficar dentro do orçamento
o Desempenho: o projeto funciona

- Cliente:

o Uso: o projeto será ou está sendo usado pelos clientes

o Satisfação: estou satisfeito com o processo de condução do projeto

o Efetividade: este projeto beneficiará diretamente os usuários

Atkinson (1999) aponta quatro fatores para entendimento dos critérios de sucesso dos projetos em projetos de sistemas de informação:

- $\quad$ Triângulo de ferro: custo, qualidade e tempo.

- Sistema de informação: necessidade de manutenção, confiabilidade, validade, qualidade da informação.

- Benefícios (organização): melhoria da eficiência, melhoria da efetividade, aumento dos lucros, metas estratégicas, aprendizado organizacional, redução de desperdício.

- Benefícios (comunidade de interessados): usuários satisfeitos, impacto social e ambiental, desenvolvimento pessoal, aprendizado profissional, 
lucro dos contratados, financiadores, equipe de projeto satisfeita, impacto econômico para a comunidade no entorno.

Westerveld (2003) sugere as seguintes categorias de critérios de sucesso para os projetos:

- Resultados do projeto (tempo, custo e qualidade/escopo)

- Apreciação do cliente

- Apreciação do pessoal do projeto

- Apreciação dos usuários

- Apreciação das contratadas

- Apreciação das partes interessadas

Shenhar e Vir (2007) sugerem cinco dimensões para critérios de sucesso de um projeto:

- Eficiência: atender metas de tempo e custo

- Impacto no consumidor: atender requisitos e atingir satisfação, benefícios e lealdade do consumidor

- Impacto na equipe: satisfação, retenção e crescimento pessoal

- Resultados para o negócio: retorno do investimento, fatia de mercado, e crescimento

- Preparação para o futuro: novas tecnologias, novos mercados e novas competências

Cada dimensão difere em detalhe, intensidade e importância, conforme o projeto. As dimensões de sucesso devem refletir os objetivos estratégicos de negócios da empresa. A eficiência é uma medida de curto prazo que verifica se o projeto foi feito dentro do prazo e dentro do orçamento. Isto não significa que um projeto bem gerido do ponto de vista da eficiência beneficiará a organização no longo prazo. No entanto, atender a meta original de tempo pode ser um fator competitivo crítico em vários projetos. 
Um complicador dos modelos vistos são as avaliações dos critérios. Como os critérios podem ser de curto ou longo prazo, algumas avaliações podem ocorrer somente após o término do projeto.

Pinto \& Slevin (1988) dizem, de maneira geral, que os fatores externos tem maior peso na avaliação de sucesso depois de um certo tempo da conclusão do projeto.

Segundo Shenhar e Dvir (2007), uma das conseqüências das dificuldades de avaliação são os incentivos aos gerentes de projeto. Afinal, apenas a medida de eficiência pode ser avaliada ao término do projeto. Os demais critérios só podem ser avaliados depois do término do projeto. A proposição dos autores para essa questão é que o modelo adaptativo provocará uma mudança cultural na organização, tornando os projetos mais sintonizados com os resultados de negócio. No longo prazo os executivos estarão mais sintonizados com os processos dos projetos e os sistemas de incentivos serão mais flexíveis e adaptativos aos múltiplos indicadores do desempenho dos projetos.

\subsection{O modelo teórico da pesquisa}

A partir da revisão bibliográfica feita foi definido o modelo teórico que orientará a coleta dos dados da pesquisa. O modelo teórico está baseado fundamentalmente no trabalho de Shenhar e Dvir (2007), que consolida cerca de 15 anos de pesquisa sobre gestão contingencial de projetos e leva em conta a contribuição de outros autores. Basicamente, foram definidas três categorias de práticas contingenciais de gestão: identificação do tipo de projeto, critérios de sucesso e adaptação da gestão.

Para cada uma dessas categorias e suas subdivisões é feita uma descrição da definição do item e da contribuição deste para o sucesso do projeto. A categoria de critérios de sucesso é subdividida em: definição dos critérios, priorização dos critérios e medição dos critérios. A categoria de adaptação da gestão de projetos é subdividida em: organização, gestão de requisitos, criação do produto e re-planejamento do projeto. O modelo teórico é descrito em detalhes na tabela 1 e nos itens seguintes. 


\begin{tabular}{|c|c|c|}
\hline Item & Definição & Contribuição para sucesso \\
\hline \multicolumn{3}{|c|}{ Início de projeto } \\
\hline $\begin{array}{l}\text { Identificação do tipo de } \\
\text { projeto }\end{array}$ & $\begin{array}{l}\text { Categorizar o projeto baseado em } \\
\text { metas estratégicas ou operacionais, } \\
\text { usuários internos ou externos, } \\
\text { inovação, tecnologia, complexidade, } \\
\text { ritmo e outras dimensões } \\
\text { relevantes. }\end{array}$ & $\begin{array}{l}\text { Modelo de classificação de projetos } \\
\text { conforme suas diferentes incertezas e } \\
\text { complexidades traz disciplina para a } \\
\text { identificação de benefícios esperados e } \\
\text { riscos dos projetos, o desenvolvimento de } \\
\text { regras e comportamentos para cada tipo de } \\
\text { projeto, a avaliação do andamento de um } \\
\text { projeto, e a comunicação entre executivos, } \\
\text { gerentes, equipes e clientes durante } 0 \\
\text { projeto. }\end{array}$ \\
\hline \multicolumn{3}{|c|}{ Critérios de sucesso } \\
\hline Definição dos critérios & $\begin{array}{l}\text { Definir as expectativas gerenciais } \\
\text { em cinco ou mais dimensões de } \\
\text { sucesso, e definir o que pode dar } \\
\text { errado. }\end{array}$ & \multirow{3}{*}{$\begin{array}{l}\text { Avaliação multidimensional do sucesso dos } \\
\text { projetos para obter projetos focados no } \\
\text { negócio e orientados para o sucesso no } \\
\text { qual o líder do projeto é responsável por } \\
\text { atingir todas as métricas de sucesso do } \\
\text { projeto. }\end{array}$} \\
\hline Priorização dos critérios & $\begin{array}{l}\text { Definir a prioridade relativa de cada } \\
\text { critério }\end{array}$ & \\
\hline Medição dos critérios & $\begin{array}{l}\text { Definir como serão medidos cada } \\
\text { um dos critérios definidos }\end{array}$ & \\
\hline \multicolumn{3}{|c|}{ Estratégias de implantação } \\
\hline Organização & $\begin{array}{l}\text { Decidir como cada categoria de } \\
\text { projeto afetará organização, } \\
\text { processos, planos, atividades, e } \\
\text { equipe (nível de formalidade, } \\
\text { comunicação, centralização vs } \\
\text { descentralização, uso de } \\
\text { subcontratados, autonomia e } \\
\text { competência das equipes, } \\
\text { freqüência de controle) }\end{array}$ & $\begin{array}{l}\text { Ao avaliar o impacto dos tipos de projetos } \\
\text { sobre a organização, processos, planos, } \\
\text { atividades e equipe, os executivos e } \\
\text { equipes tem oportunidade de } \\
\text { definir/redefinir estes elementos de forma a } \\
\text { aumentar as chances de sucesso. }\end{array}$ \\
\hline Gestão de requisitos & $\begin{array}{l}\text { Estimar as incertezas dos requisitos } \\
\text { iniciais } \\
\text { Coleta de dados de mercado } \\
\text { Quantidade de protótipos de } \\
\text { mercado } \\
\text { Momento do congelamento de } \\
\text { requisitos } \\
\text { Refinamento dos requisitos do } \\
\text { produto } \\
\text { Congelamento dos requisitos de } \\
\text { produto }\end{array}$ & $\begin{array}{l}\text { Contribuem para entender as expectativas } \\
\text { dos consumidores, em projetos inovadores, } \\
\text { sobre os resultados do projeto, diminuindo } \\
\text { a chance de retrabalhos. Possibilita ainda o } \\
\text { dimensionamento de contingências de } \\
\text { tempo e custo. }\end{array}$ \\
\hline Criação do produto & $\begin{array}{l}\text { Quantidade de ciclos de design } \\
\text { Momento de congelamento do } \\
\text { design } \\
\text { Construção e teste do protótipo } \\
\text { Ciclos adicionais de design } \\
\text { (redesenho, reconstrução e re-teste) } \\
\text { Congelamento das especificações e } \\
\text { do design do produto }\end{array}$ & $\begin{array}{l}\text { Contribuem para diminuir as chances de } \\
\text { riscos técnicos do não funcionamento do } \\
\text { resultado de projetos com incerteza } \\
\text { tecnológica. Possibilita ainda o } \\
\text { dimensionamento de contingências de } \\
\text { tempo e custo. }\end{array}$ \\
\hline Re-planejamento do projeto & $\begin{array}{l}\text { Atualizar os planos e fazer } \\
\text { mudanças }\end{array}$ & $\begin{array}{l}\text { Contribuem para a flexibilização do projeto } \\
\text { às realidades dos negócios. }\end{array}$ \\
\hline
\end{tabular}




\subsubsection{Início de projeto}

Shenhar e Dvir (2007) sugerem a utilização de um modelo de classificação de projetos baseado em quatro dimensões: inovação, tecnologia, complexidade e ritmo. O conjunto dessas dimensões avalia a complexidade e incerteza das metas, das atividades e do ambiente no qual o projeto se insere.

A dimensão de inovação é definida considerando o grau de novidade do produto ou resultado do projeto para o mercado e potenciais usuários. O grau de inovação representa o nível de familiaridade com o produto, com seu uso e seus benefícios. Representa também a incerteza da meta do projeto, ou seja, o quanto claramente é possível definir os requisitos e necessidades dos usuários ou consumidores antecipadamente. Shenhar e Dvir (2007) sugerem três graus de inovação:

- Inovação

o Derivativo: produtos são extensões e melhorias de produtos existentes

o Plataforma: produtos são novas gerações de produtos existentes

o Ruptura: produtos são novidades que os consumidores ou usuários nunca viram antes, vindas de um novo conceito ou idéia.

A dimensão de tecnologia está associada à incerteza das atividades do projeto. Shenhar e Dvir (2007) sugerem quatro graus de incerteza da tecnologia:

- Tecnologia

o Baixa tecnologia: projetos que se apóiam em tecnologias bem estabelecidas.

o Média tecnologia: projetos usam predominantemente tecnologias bem estabelecidas, mas incorporam alguma nova tecnologia que não existia em projetos anteriores. 
o Alta tecnologia: projetos usam tecnologias novas para a empresa, mas que já existem.

o Super alta tecnologia: projetos que se baseiam em tecnologias que não existem no início do projeto.

A dimensão de complexidade está associada ao nível de escopo do projeto. Shenhar e Dvir (2007) sugerem três graus de complexidade do escopo:

- Montagem: projetos envolvem a criação de uma coletânea de elementos, componentes e módulos combinados em uma unidade única que executa uma única função.

- Sistema: projetos envolvem uma coletânea complexa de elementos e subsistemas interativos, que juntos realizam múltiplas funções que atendem uma necessidade operacional específica.

- Grandes sistemas: projetos envolvem grandes e dispersas coletâneas de sistemas que funcionam juntos para atingir um propósito comum.

A dimensão de ritmo a urgência do tempo para entregar os resultados do projeto. Shenhar e Dvir (2007) sugerem três graus de complexidade do escopo:

- Regular: projetos que não tem o tempo como elemento crítico para o sucesso imediato da organização.

- Rápido/Competitivo: projetos que tem o tempo como elemento importante para o sucesso organizacional.

- Crítico: projetos que tem o tempo como elemento crítico para o sucesso organizacional.

- Blitz: projetos urgentes para resolver crises.

A investigação da forma como as empresas diferenciam seus projetos usará o modelo de Shenhar e Dvir (2007), mas como eles mesmos reconhecem, não ficará limitada apenas às dimensões propostas. 


\subsubsection{Critérios de sucesso}

Os diferentes graus de incerteza associadas ao mercado (inovação) e à incerteza tecnológica afetam as expectativas de sucesso dos projetos. O modelo multidimensional sugerido por Shenhar e Dvir (2007) tem muita semelhança com o modelo de critérios de sucesso sugerido anteriormente por Pinto e Slevin (1989). Para esta pesquisa foi adotado o modelo de Shenhar e Dvir (2007) como referência para a coleta de dados.

As tabelas 2 e 3 apresentadas a seguir relacionam as dimensões de sucesso com as incertezas de mercado e de tecnologia e ajudarão a orientar a coleta dos dados na pesquisa.

\begin{tabular}{|c|c|c|c|}
\hline \multirow{2}{*}{$\begin{array}{l}\text { Dimensões de sucesso } \\
\text { e possíveis fracassos }\end{array}$} & \multicolumn{3}{|c|}{ Grau de inovação do projeto } \\
\hline & Derivativo & Plataforma & Ruptura \\
\hline Eficiência & $\begin{array}{l}\text { Alta eficiência é crítico; } \\
\text { sem espaço para atrasos }\end{array}$ & $\begin{array}{l}\text { Tempo para mercado é } \\
\text { importante para vantagem } \\
\text { competitiva }\end{array}$ & $\begin{array}{l}\text { Eficiência é difícil de } \\
\text { atingir e pode não ser } \\
\text { crítica (a menos que os } \\
\text { competidores trabalhem } \\
\text { na mesma idéia); atrasos } \\
\text { prováveis }\end{array}$ \\
\hline Impacto no consumidor & $\begin{array}{lr}\text { Ganhar } & \text { consumidores } \\
\text { adicionais e segmentos } \\
\text { de mercado }\end{array}$ & $\begin{array}{l}\text { Ter alto impacto } \\
\text { estratégico nos } \\
\text { consumidores; reter } \\
\text { consumidores das } \\
\text { gerações anteriores do } \\
\text { produto }\end{array}$ & $\begin{array}{l}\text { Melhorias significativas na } \\
\text { vida e trabalho do } \\
\text { consumidor }\end{array}$ \\
\hline Impacto na equipe & $\begin{array}{l}\text { Equipe amplia sua } \\
\text { experiência em rápidas } \\
\text { modificações de produto }\end{array}$ & 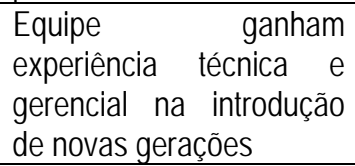 & $\begin{array}{l}\text { Equipe explora novos } \\
\text { campos e ganham } \\
\text { experiência em mercados } \\
\text { desconhecidos }\end{array}$ \\
\hline Sucesso do negócio & $\begin{array}{l}\text { Amplia a vida de produtos } \\
\text { existentes; receitas } \\
\text { adicionais e mantém fluxo } \\
\text { produtos atuais }\end{array}$ & $\begin{array}{l}\text { Alto impacto estratégico } \\
\text { no negócio; expectativa } \\
\text { de anos de receitas e } \\
\text { construção de derivativos } \\
\text { adicionais. }\end{array}$ & $\begin{array}{l}\text { Sucesso significativo de } \\
\text { longo prazo; pode vir } \\
\text { mais tarde, depois do } \\
\text { teste e refinamento dos } \\
\text { produtos iniciais. }\end{array}$ \\
\hline Preparação para o futuro & Quase nenhuma & $\begin{array}{l}\text { Manter uma posição } \\
\text { estratégica no mercado }\end{array}$ & $\begin{array}{l}\text { Criar novos mercados e } \\
\text { estabelecer posições de } \\
\text { liderança }\end{array}$ \\
\hline $\begin{array}{l}\text { Possíveis fracassos e } \\
\text { riscos }\end{array}$ & $\begin{array}{l}\text { Baixo risco; risco pode } \\
\text { envolver atraso e ganhos } \\
\text { de valor marginais. }\end{array}$ & $\begin{array}{l}\text { Risco médio; risco pode } \\
\text { envolver fracasso em ter } \\
\text { progressor suficiente } \\
\text { comparado com gerações } \\
\text { anteriores, ou mesmo } \\
\text { perder uma geração no } \\
\text { mercado. }\end{array}$ & $\begin{array}{l}\text { Alto risco; risco envolve } \\
\text { fracasso em atender uma } \\
\text { real necessidade dos } \\
\text { consumidores, fracasso } \\
\text { em vender a idéia para } \\
\text { consumidores, ou } \\
\text { fracasso em avaliar o } \\
\text { tamanho real do mercado. }\end{array}$ \\
\hline
\end{tabular}

Tabela 2 - Critérios de sucesso conforme o grau de inovação 


\begin{tabular}{|c|c|c|c|c|}
\hline \multirow{2}{*}{$\begin{array}{l}\text { Dimensões de } \\
\text { sucesso e } \\
\text { possíveis } \\
\text { fracassos }\end{array}$} & \multicolumn{4}{|c|}{ Grau de incerteza tecnológica } \\
\hline & Baixa & Média & Alta & Super-alta \\
\hline Eficiência & $\begin{array}{l}\text { Alta eficiência é } \\
\text { crítico }\end{array}$ & $\begin{array}{l}\text { Eficiência } \\
\text { importante }\end{array}$ & $\begin{array}{lr}\text { Atrasos } & \text { podem } \\
\text { ocorrer; r não } \\
\text { espere isso, mas } \\
\text { aceite-os quando } \\
\text { acontecerem }\end{array}$ & Alta chance de atrasos \\
\hline $\begin{array}{l}\text { Impacto no } \\
\text { consumidor }\end{array}$ & Produto padrão & $\begin{array}{l}\text { Produto funcional; } \\
\text { Adiciona valor ao } \\
\text { consumidor }\end{array}$ & $\begin{array}{l}\text { Melhora } \\
\text { significativa as } \\
\text { competências do } \\
\text { consumidor }\end{array}$ & $\begin{array}{l}\text { Salto quântico na } \\
\text { efetividade do consumidor }\end{array}$ \\
\hline $\begin{array}{l}\text { Impacto na } \\
\text { equipe }\end{array}$ & $\begin{array}{lr}\text { Amplia } & a \\
\text { experiência } & d a \\
\text { equipe no setor } & \end{array}$ & $\begin{array}{lr}\text { Amplia } & \text { a } \\
\text { experiência } & \text { da } \\
\text { equipe em designs } \\
\text { rápidos } & \text { e } \\
\text { modificações } & \text { de } \\
\text { produto } & \\
\end{array}$ & $\begin{array}{lr}\text { Amplia } & 0 \\
\text { aprendizado } & \text { da } \\
\text { equipe } & \text { na } \\
\text { aplicação } & \text { de } \\
\text { novas tecnologias }\end{array}$ & $\begin{array}{l}\text { Constrói líderes técnicos } \\
\text { no desenvolvimento de } \\
\text { tecnologias } \\
\text { desconhecidas }\end{array}$ \\
\hline $\begin{array}{l}\text { Sucesso do } \\
\text { negócio }\end{array}$ & Lucro razoável & $\begin{array}{lr}\text { Lucro } & \text { moderado; } \\
\text { retorno } & \text { médio } \\
\text { sobre } & 0 \\
\text { investimento } & \\
\end{array}$ & $\begin{array}{l}\text { Alto lucro; alta fatia } \\
\text { de mercado }\end{array}$ & $\begin{array}{ll}\text { Resultados } & \\
\text { extraordinários no longo } \\
\text { prazo; posição de } \\
\text { liderança no mercado }\end{array}$ \\
\hline $\begin{array}{l}\text { Preparação para } \\
\text { o futuro }\end{array}$ & Quase nenhuma & $\begin{array}{l}\text { Traz competências } \\
\text { organizacionais } \\
\text { adicionais }\end{array}$ & $\begin{array}{l}\text { Nova linha de } \\
\text { produto; novo } \\
\text { mercado }\end{array}$ & $\begin{array}{l}\text { Posição de liderança; } \\
\text { novas tecnologias }\end{array}$ \\
\hline $\begin{array}{l}\text { Possíveis } \\
\text { fracassos e } \\
\text { riscos }\end{array}$ & $\begin{array}{l}\text { Baixo, sem risco } \\
\text { específico vindo da } \\
\text { tecnologia usada }\end{array}$ & $\begin{array}{lr}\text { Risco } & \text { moderado } \\
\text { vindo } & \text { da } \\
\text { tecnologia } & \end{array}$ & $\begin{array}{lr}\text { Alto risco } & \text { de } \\
\text { atrasos, } & \text { custos } \\
\text { adicionais } & \text { e } \\
\text { desempenho } & \\
\text { indesejável } & \text { vindas } \\
\text { do uso r de } \\
\text { tecnologias pela } \\
\text { primeira vez }\end{array}$ & $\begin{array}{l}\text { Risco alto de tecnologias } \\
\text { desconhecidas; atrasos } \\
\text { excessivos e robre- } \\
\text { custos, com possível } \\
\text { fracasso no produto ou } \\
\text { fracasso em atingir o } \\
\text { desempenho esperado. }\end{array}$ \\
\hline
\end{tabular}

Tabela 3 - Critérios de sucesso e grau conforme o grau de incerteza tecnológica

Fonte Shenhar e Dvir (2007)

\subsubsection{Estratégias de implantação}

Esta categoria de práticas gerenciais envolve a adaptação da gestão de projetos às diferenças dos projetos. A premissa da gestão contingencial é entender o projeto como um processo imprevisível, não-linear e iterativo. Muitas coisas ainda são desconhecidas durante o lançamento do projeto; as premissas iniciais são bastante incertas, e muitas decisões provavelmente mudarão durante o projeto. A Tabela 4 mostra os pontos de preocupação da gestão de projetos conforme o tipo de projeto. 


\begin{tabular}{|l|l|}
\hline Dimensão & Pontos de preocupação \\
\hline Inovação & $\begin{array}{l}\text { Duração da fase de definição; quantidade de iterações nos } \\
\text { requisitos; momento do congelamento dos requisitos; } \\
\text { necessidade de protótipos para testes de mercado; métodos } \\
\text { de marketing; gestão de riscos }\end{array}$ \\
\hline Tecnologia & $\begin{array}{l}\text { Quantidade de ciclos de design; momento do congelamento } \\
\text { do design; extensão de riscos do projeto; quantidade e tipo } \\
\text { de protótipos; tipo de contrato; competência técnica da } \\
\text { equipe }\end{array}$ \\
\hline Complexidade & $\begin{array}{l}\text { Nível de formalidade; tipo de reporte e comunicação; } \\
\text { extensão da integração de sistemas; uso de subcontratados; } \\
\text { estrutura organizacional; centralização vs descentralização; } \\
\text { gestão de riscos. }\end{array}$ \\
\hline Ritmo & $\begin{array}{l}\text { Autonomia das equipes de projeto; freqüência de de } \\
\text { monitoramento e controle; planos de contingência; } \\
\text { improvisação. }\end{array}$ \\
\hline
\end{tabular}

Tabela 4 - Pontos de preocupação na gestão dos projetos nas dimensões de classificação

Fonte: Adaptado pelo autor de Shenhar e Dvir (2007)

Segundo Shenhar e Dvir (2007), uma das funções de um gerente de projetos é gerenciar as incertezas do projeto: como distingui-las, como defini-las antecipadamente e como controlar e reduzi-las durante a execução do projeto. Shenhar e Dvir (2007) consideram que os principais tipos de incerteza estão associados ao mercado e/ou às especificações técnicas. A Tabela 5 ilustra um ciclo de vida genérico e os pontos de adaptação à gestão contingencial (em negrito).

\begin{tabular}{|l|l|l|}
\hline Fase & Atividade & Detalhes \\
\hline Definição & $\begin{array}{l}\text { Definição do } \\
\text { mercado }\end{array}$ & $\begin{array}{l}\text { Identificação do mercado/consumidor } \\
\text { Necessidade do consumidor }\end{array}$ \\
\cline { 2 - 3 } & $\begin{array}{l}\text { Objetivo de } \\
\text { negócio }\end{array}$ & $\begin{array}{l}\text { Definir o objetivo de negócio esperado que será atingido quando o projeto } \\
\text { acabar }\end{array}$ \\
\cline { 2 - 3 } & $\begin{array}{l}\text { Definição do } \\
\text { produto }\end{array}$ & $\begin{array}{l}\text { Descrição do produto } \\
\text { Requisitos do produto }\end{array}$ \\
\cline { 2 - 3 } & $\begin{array}{l}\text { Definição do } \\
\text { projeto }\end{array}$ & $\begin{array}{l}\text { Escopo } \\
\text { Duração aproximada } \\
\text { Orçamento aproximado } \\
\text { Gerente e equipe do projeto }\end{array}$ \\
& $\begin{array}{l}\text { Categorizar o projeto baseado em metas estratégicas ou operacionais, } \\
\text { usuários internos ou externos, inovação, tecnologia, complexidade, ritmo e } \\
\text { outras dimensões relevantes. }\end{array}$ \\
\cline { 2 - 3 } & projeto \\
\cline { 2 - 3 } & $\begin{array}{l}\text { Critérios de } \\
\text { sucesso e } \\
\text { fracasso }\end{array}$ & $\begin{array}{l}\text { Definir as expectativas gerenciais em cinco ou mais dimensões de } \\
\text { sucesso, e definir o que pode dar errado. }\end{array}$ \\
\hline Planejamento & $\begin{array}{l}\text { Impacto do } \\
\text { tipo de } \\
\text { projeto na } \\
\text { gestão do } \\
\text { projeto }\end{array}$ & $\begin{array}{l}\text { Decidir como cada categoria de projeto afetará a organização, processos, } \\
\text { planos, atividades, e equipe }\end{array}$ \\
\hline
\end{tabular}




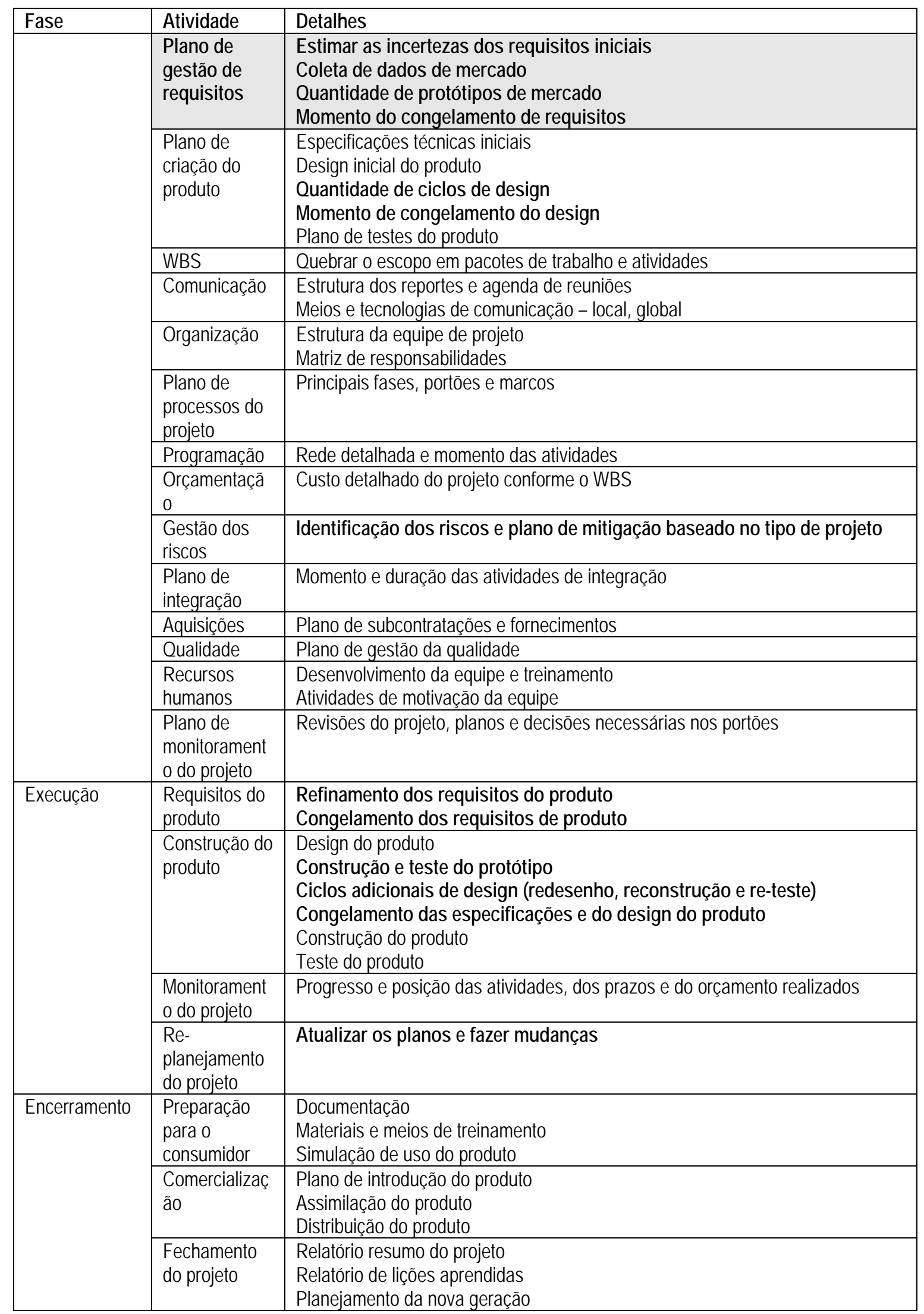

Tabela 5 - Itens necessários para adaptação do ciclo de vida de projeto

Fonte: Shenhar e Dvir (2007) 


\section{Capítulo 4}

\section{Metodologia}

\subsection{Tipo de estudo}

A natureza deste trabalho é descritiva, pois pretende descrever aspectos da gestão de projetos complexos e incertos em empresas no Brasil para entender porque e como a abordagem contingencial estruturada de gestão pode contribuir para o aumento da taxa de sucesso desses projetos.

Segundo Yin(2005), independente da natureza investigativa do trabalho, existem três condições para escolha da melhor estratégia de pesquisa: o tipo de questão de pesquisa proposta, a extensão de controle que o pesquisador tem sobre eventos comportamentais atuais e o grau de enfoque em acontecimentos contemporâneos.

Considerando estas condições no contexto deste trabalho, o método mais adequado de pesquisa é o estudo de múltiplos casos, pois trata-se de uma análise contemporânea de uma situação, na qual o pesquisador não tem qualquer influência ou controle sobre comportamentos relevantes. O desenho das etapas do método de estudo de múltiplos casos é apresentado na figura 2. 


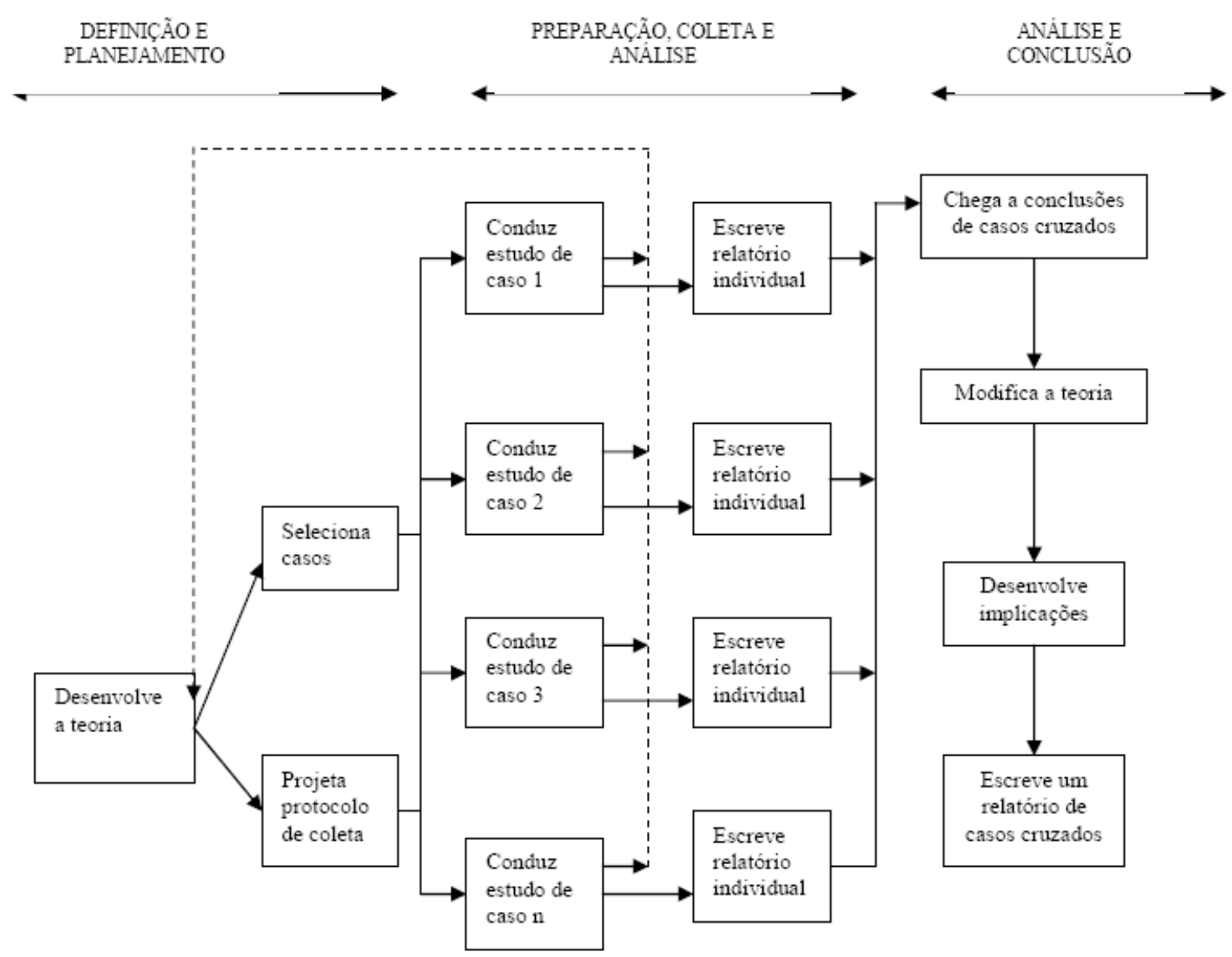

Figura 2: Etapas do método de estudo de caso

Fonte: Yin, 2005

Segundo Eisenhardt (1989), um estudo de caso pode ser utilizado para testar ou gerar uma teoria. O processo para gerar uma teoria a partir de um estudo de caso único ou múltiplo tem as seguintes etapas: 1) definição do problema; 2) seleção dos casos a serem analisados; 3) definição dos instrumentos de coleta de dados e protocolos; 4) coleta de dados; 5) análise dos dados; 6) formação das hipóteses; 7) comparação com a literatura existente; 8) encerramento da pesquisa.

Um passo importante para condução do estudo é o desenvolvimento de uma estrutura teórica consistente. O modelo teórico que orienta esta pesquisa é baseado nos trabalhos de Shenhar (1996,1998,1999,2001,2002), Raz, Shenhar e Dvir (2003), Shenhar e Dvir (2007) sobre gestão contingencial de projetos. A partir da revisão da teoria foram estabelecidas as categorias de práticas de gestão contingencial a serem observadas e descritas nas organizações selecionadas para os estudos de caso: análises iniciais para 
diferenciar e categorizar os projetos; adaptação das práticas de gestão de projetos às características de cada projeto; e adequação dos critérios de sucesso às características de cada projeto. A partir destas categorias foi possível estabelecer o modelo teórico da pesquisa (apresentado no ítem 3.4 deste trabalho) e estruturar o instrumento de coleta dos dados (veja item 4.3 e apêndice).

\subsection{Seleção dos casos}

Segundo Eisenhardt (1989), os casos a serem estudados podem ser escolhidos para replicar casos previamente estudados, ampliar uma teoria emergente, ou ainda preencher categorias teóricas ou prover exemplos de tipos específicos. Estas escolhas são chamadas de amostragem teórica. A amostra não é aleatória, mas reflete a seleção de casos específicos para estender a teoria para uma ampla variedade de elementos.

A quantidade de casos a serem estudados deve ser feita de acordo com o tipo de questão de pesquisa proposta. Eisenhardt (1989) avalia que o número de casos adequado para um bom estudo varia de quatro a dez. Yin (2005) considera que estudos com quatro a seis casos podem ser projetados para buscar padrões diferentes de replicações teóricas.

Segundo Yin (2005), se todos os casos se mostrarem previsíveis, no conjunto, fornecerão uma base convincente para o conjunto inicial de proposições. Um passo importante para a replicação é o desenvolvimento de uma rica estrutura teórica.

Nesta pesquisa pretende-se analisar seis casos. As unidades de análise serão empresas que tenham projetos complexos e incertos em seus portfólios e atuem no Brasil. Utilizando a classificação de tipos básicos de projetos para estudos de caso sugerido por Yin (2005), conforme mostra a Tabela 6, esta pesquisa utilizará o tipo projetos de múltiplos casos holístico (com apenas uma unidade de análise para cada caso). O foco da análise será a maneira como cada empresa trata os elementos da gestão contingencial para o conjunto de seus projetos. 


\begin{tabular}{|l|l|l|}
\hline & $\begin{array}{l}\text { Projetos de caso } \\
\text { único }\end{array}$ & $\begin{array}{l}\text { Projetos de casos } \\
\text { múltiplos }\end{array}$ \\
\hline $\begin{array}{l}\text { Holístico } \\
\text { (unidade única } \\
\text { de análise) }\end{array}$ & $\begin{array}{l}\text { Um caso inserido num } \\
\text { contexto }\end{array}$ & $\begin{array}{l}\text { Vários casos, cada } \\
\text { um com seu contexto }\end{array}$ \\
\hline $\begin{array}{l}\text { Incorporado } \\
\text { (unidades } \\
\text { múltiplas de } \\
\text { análise) }\end{array}$ & $\begin{array}{l}\text { Un caso com unidades } \\
\text { incorporadas de } \\
\text { inseridos ambos num contexto }\end{array}$ & $\begin{array}{l}\text { Vários casos, cada } \\
\text { um com unidades } \\
\text { incorporadas de } \\
\text { análise e contextos } \\
\text { próprios. }\end{array}$ \\
\hline
\end{tabular}

Tabela 6:Tipos básicos de projetos de estudo de caso

Fonte: Adaptado de Yin (2005)

Para selecionar as empresas estudadas, inicialmente foi feita uma lista mais ampla de empresas que poderiam ser objeto dos estudos de caso, conforme os seguintes critérios:

- Empresas que estejam gerenciando ou tenham gerenciado recentemente projetos com pelo menos duas das seguintes características:

i. Escopo amplo (abrangência, quantidade de interfaces)

ii. Uso de tecnologia pouco conhecida

iii. Produto gerado pelo projeto seja inovador para o consumidor (interno ou externo)

iv. Tempo disponível para implantação seja crítico

- Facilidade de acesso do pesquisador 
As empresas selecionadas como unidades de análise foram as seguintes:

\begin{tabular}{|c|l|c|l|l|}
\hline Empresa & Setor & $\begin{array}{l}\text { Quantidade de } \\
\text { entrevistas }\end{array}$ & Setor entrevistado & Cargos dos Entrevistados \\
\hline 1 & Bens de consumo & 2 & PMO Estratégico & Analistas de Gestão de Projetos \\
\hline 2 & Siderurgia & 1 & Tecnologia de Gestão & Chefe de Tecnologia de Gestão \\
\hline 3 & Financeiro & 3 & Comercial/Varejo & Superintendentes \\
\hline 4 & Mineração & 1 & Projetos de Engenharia & Gerente Geral de Engenharia \\
\hline 5 & Bens de consumo & 2 & Centro de Engenharia & Gerente Geral de Engenharia \\
\hline
\end{tabular}

Tabela 7: Setor econômico das empresa, quantidade de entrevistas e área interna

Fonte: Elaborado pelo autor

Após a definição dos casos da pesquisa, a próxima etapa foi a definição do protocolo de coleta de dados, com a estruturação do instrumento de coleta de dados.

\subsection{Protocolo de coleta de dados}

Como preparação para a coleta de dados, Yin (2005) recomenda o desenvolvimento de um protocolo de coleta para cada estudo de caso. Este protocolo deve ter as seguintes seções: visão geral do projeto do estudo de caso; procedimentos de campo; questões do estudo de caso; guia para o relatório do estudo de caso.

A visão geral do projeto do estudo de caso foi mostrada no capítulo 2 e no ítem 4.2 , onde foram estabelecidos o objetivo da pesquisa, as questões de pesquisa; as proposições; a justificativa do estudo e a seleção dos casos.

Para os procedimentos de campos, Yin (2005) recomenda que o pesquisador atente para os seguintes pontos quanto aos procedimentos: obter acesso a organizações ou entrevistados-chave; possuir recursos suficientes enquanto estiver no campo; desenvolver um procedimento para pedir ajuda e orientação; estabelecer uma agenda clara das atividades de coleta de dados; preparar-se para mudanças inesperadas. 
A pesquisa que foi feita identificou as empresas potenciais e as pessoas de contato para a realização dos estudos de caso, conforme foi apresentado no item anterior. Os recursos para a coleta dos dados foram um bloco de notas e um gravador de voz para registro das entrevistas. As ajudas e orientações vieram do contato com o orientador formal da pesquisa e de conversas com outros professores e colegas. A coleta de dados foi feita nos meses de outubro, novembro e dezembro de 2008. As entrevistas tiveram duração de 45 minutos a uma hora e meia.

Segundo Yin (2005), as questões do estudo de caso são o ponto central do protocolo de pesquisa do método. As questões de protocolo são, em essência, os lembretes que o pesquisador utilizará para lembrar das informações que precisam ser coletadas e o motivo para coletá-las. Partindo das questões de pesquisa levantadas e do referencial teórico escolhido para a pesquisa, foram listadas as questões investigativas específicas que serviram de orientação para o pesquisador conduzir as entrevistas. A inserção das questões do estudo de caso no protocolo de coleta de dados é discutida a seguir.

\subsection{Instrumento de coleta de dados}

Eisenhardt (1989) comenta que os pesquisadores combinam múltiplas técnicas de coleta de dados para construir uma teoria. Apesar da entrevista, das observações e da pesquisa em arquivos serem as técnicas mais comuns, os pesquisadores não estão confinados a empregar somente estas alternativas. Para estudos de casos, é possível combinar diferentes métodos de coleta de dados, entre eles a pesquisa em arquivos, entrevistas, questionários e observações. Yin (2005) cita seis fontes distintas de evidências: documentos, registros em arquivo, entrevistas, observação direta, observação participante e artefatos físicos.

Nesta pesquisa serão utilizados os seguintes instrumentos de coleta de dados: entrevista semi-estruturada, observação direta e pesquisa em arquivos. As entrevistas foram concedidas por profissionais e/ou executivos das empresas selecionadas que tiveram envolvimento na gestão de projetos complexos e incertos e as observações diretas feitas pelo pesquisador foram 
as fontes de dados primários da pesquisa. A pesquisa em arquivo, para obtenção de dados secundários, foi feita no web site da empresa, nas publicações sobre as empresas e nos documentos internos que foram disponibilizados para o pesquisador.

Numa etapa anterior às entrevistas foi realizada uma análise de conteúdo das fontes secundárias disponíveis, buscando informações que ajudassem na elaboração dos casos. Por exemplo, foram analisados os relatórios de relacionamento com investidores para tentar identificar projetos com as características de complexidade e incerteza descritas no item anterior.

Foram entrevistadas pessoas que trabalhavam nas empresas selecionadas e que tiveram participação na gestão de projetos complexos e incertos. Foram feitas 12 entrevistas no total, contemplando as seis empresas selecionadas. Em metade das entrevistas foi possível enviar previamente um caso preliminar com a caracterização da empresa e as práticas de gestão contingencial de projetos previamente identificadas pela análise de conteúdo. O objetivo desta ação tornou as entrevistas mais focadas e objetivas.

Com os dados secundários levantados, foi pedido que os entrevistados descrevessem os aspectos relacionados ao início, critérios de sucesso e adaptação da gestão de projetos complexos e incertos. Após esgotar o tópico de práticas de gestão contingencial, foi pedido aos entrevistados que avaliassem como as práticas observadas contribuíam para o sucesso dos projetos do ponto de vista do negócio. Dois terços das entrevistas foram gravadas e transcritas ipsis verbis para posterior análise dos dados.

O instrumento de coleta de dados é apresentado no Apêndice I deste trabalho. A estrutura do instrumento de coleta tem a intenção de servir de orientação para a ligação das questões propostas na pesquisa e os objetivos do trabalho.

A seção "projetos" do instrumento de coleta de dados permitiu conhecer os principais projetos complexos e incertos das empresas. O modelo de classificação de projetos sugerido por Shenhar e Dvir (2007) ajuda a descrever melhor os projetos descritos pelos entrevistados. 
Na seção "descrição das análises iniciais", o objetivo era que o entrevistado descrevesse o processo utilizado pela empresa para categorizar os projetos. Os pontos de atenção do pesquisador foram a verificação da existência de alguma forma pré-determinada de classificação e a verificação da percepção de entendimento das dimensões de diferenciação do modelo de Shenhar e Dvir (2007), ou seja, inovação, tecnologia, complexidade e ritmo.

Na seção "adaptação", o objetivo foi discutir práticas de adaptação da gestão de projetos ao tipo dos projetos. Para orientar a entrevista, o pesquisador deveria observar os seguintes pontos: verificar se existe alguma metodologia de gestão de projetos; verificar se existe alguma adaptação na metodologia de acordo com o projeto; verificar como se dá a adaptação, solicitando aos entrevistados um exemplo de projeto para cada dimensão utilizada no modelo de classificação de Shenhar e Dvir (2007). Para melhor aproveitamento dos exemplos, foram listados no instrumento de coleta os principais pontos da gestão de projetos que precisam ser adaptados em cada dimensão.

Por fim, a seção "critérios de sucesso" teve por objetivo discutir a maneira como a empresa define e mede os critérios de sucesso de seus projetos. Para tanto, o pesquisador deveria ficar atento aos seguintes pontos: identificar os critérios utilizados pela empresa em seus projetos; verificar o peso destes critérios em diferentes projetos; verificar como a empresa efetua as medições destes critérios; verificar se o gerente de projetos responde pelo sucesso do projeto e de seu resultado.

\subsection{Limitações do método de pesquisa}

A metodologia de estudos de casos é aceita como método de pesquisa, mas há críticas referentes à sua confiabilidade e à generalização de resultados dos casos analisados.

A questão da confiabilidade pode ser resolvida com uma determinação cuidadosa das perguntas de pesquisa, das suas proposições, do relacionamento entre os dados e as proposições e dos critérios de interpretação a serem utilizados (Yin, 2005). 
A questão da generalização dos resultados não é relevante nesta pesquisa, pois se pretendeu desenvolver uma replicação teórica. No entanto, ao final da pesquisa foi avaliada a qualidade do trabalho através do modelo de testes de avaliação de caso sugerido por Yin (2005): validade do constructo, validade interna, validade externa, confiabilidade.

Para validar o constructo desta pesquisa foram utilizadas fontes múltiplas de evidências, tais como: análise de informações em web sites; análise de relatórios de investidores; consulta de publicações em periódicos nacionais e internacionais sobre as empresas estudadas; observação direta e entrevistas com executivos, gerentes e equipes de projeto das empresas. O encadeamento de evidências foi obtido com a análise prévia de conteúdo. A descrição de cada caso foi validada com os entrevistados respectivos.

Para validade interna foi feita a apresentação padrão das categorias e práticas de gestão contingencial para todas as empresas. Tal procedimento permitiu a análise cruzada dos dados.

Para a validade externa foi utilizada a lógica da replicação da teoria entre os seis casos estudados. Para a confiabilidade do estudo foi utilizado o protocolo de estudo de cada caso, com registro de todas as atividades realizadas em cada empresa desde os contatos para participar do estudo até as agendas para as entrevistas. 


\section{Capítulo 5}

\section{Apresentação dos casos estudados}

Para apresentar as organizações que foram pesquisadas, cada caso está composto por três seções: (1) uma caracterização da empresa e um breve histórico; (2) descrição dos três aspectos observados na gestão de projetos complexos e incertos: início de projeto; estratégias de implantação e critérios de sucesso e fracasso; (3) contribuição das práticas observadas para o sucesso do projeto utilizando o modelo de Shenhar e Dvir (2007).

\subsection{Estudo de caso 1}

Empresa do setor agroindustrial que produz alimentos derivados de carne suína, bovina, de frango e de peru, além de massas, margarinas e sobremesas. É líder nacional nos segmentos de alimentos industrializados, aves e suínos, além de ser uma das principais exportadoras do país.

Companhia aberta desde 1971, a empresa mantém um parque fabril com 14 unidades industriais, duas unidades agropecuárias e centros de distribuição espalhados por sete estados brasileiros. No exterior a empresa tem escritórios comerciais em 11 países - Panamá, Chile, Uruguai, Argentina, Alemanha, Inglaterra, Rússia, Turquia, Emirados Árabes, China e Japão.

Ao longo de sua história de mais de 60 anos, a empresa evoluiu baseada em duas estratégias: a diversificação de seu portfólio de produtos alimentícios, e o investimento na qualidade. No final dos anos 1980 e começo dos anos 1990, a política de expansão da empresa deu lugar à racionalização da gestão e de suas estruturas de custos através do agrupamento de várias empresas do grupo. O grupo começou a década de 1990 com 21 empresas, e começou a concentrar suas operações em produtos industrializados de carne. 
A partir de 1997, a gestão da empresa continuou a reestruturação do grupo e implementou sua estratégia de foco em produtos industrializados de maior valor agregado. Ainda em 1997, a empresa vendeu uma unidade de abate de gado, quatro unidades de processamento de soja, 12 centros de compra e armazenagem de grãos. Além disso, o transporte de produtos foi terceirizado. Em 1998, o grupo uniu suas duas subsidiárias e formou uma única empresa. Isto foi resultado de um processo gradual de reorganização que buscou simplificar a estrutura do grupo, aumentar a visibilidade para os mercados de capital, e obter ganhos de escala através da redução de despesas gerais e administrativas e de impostos.

A evolução da composição do faturamento da empresa reflete a estratégia focada em produtos industrializados de maior valor agregado, iniciada em 1997. As composições do faturamento no mercado interno e no mercado externo da empresa em 2007 foram as seguintes:

- Mercado interno: 80\% industrializados; 6\% aves partes; 3\% aves inteiras; $3 \%$ suínos; $1 \%$ bovinos; $7 \%$ outros.

- Mercado externo: 10\% industrializados; 35\% aves partes; 35\% aves inteiras; $11 \%$ suínos; $7 \%$ bovinos; $2 \%$ outros

Comparando os anos 2000 e 2007, a participação dos produtos industrializados no mercado doméstico aumentou de aproximadamente $64 \%$ para $80 \%$.

A composição acionária da empresa em 2007 tinha cerca de 60\% do total de ações ON e PN pulverizadas entre investidores. O restante 40\% das ações está dividido entre cinco agrupamentos de acionistas. As ações da empresa são negociadas em três bolsas de valores: Bovespa - Brasil, NYSE - Nova York, e Latibex - Madrid.

A empresa emprega cerca de 52 mil funcionários e mantém parceria com cerca de 10.000 granjas integradas de aves e de suínos. No ano de 2007, a empresa teve uma receita operacional bruta de $\mathrm{R} \$ 9,844$ bilhões e um lucro líquido de R\$ 689 milhões, resultando numa margem de 8,0\%. 
A empresa iniciou o processo de internacionalização de suas operações com a construção de sua primeira unidade industrial na cidade de Kaliningrado, na Rússia. A unidade irá atender ao mercado local e de outros países da região e fornecer produtos para a rede McDonald's naquele país. Outra unidade industrial fora do Brasil está programada para ser implantada nos Emirados Arábes em 2008.

O plano de investimentos da empresa previa dispêndio de $\mathrm{R} \$ 1,6$ bilhão para 2008, destinados à expansão da capacidade produtiva no Brasil e no exterior, tecnologia da informação, infra-estrutura de distribuição e matrizes. A expectativa da empresa era crescer de $12 \%$ a $14 \%$ em volume de vendas em 2008 e dobrar o faturamento em cinco anos.

A empresa investe em pesquisa e desenvolvimento de novos produtos e na permanente melhoria da qualidade dos seus itens comercializados. O foco é o desenvolvimento de produtos industrializados de alto valor agregado e na inovação e melhoria de processos industriais, visando reduzir custos de produção.

\subsubsection{Início dos projetos}

A origem dos projetos complexos e incertos na empresa está normalmente ligada ao processo de planejamento estratégico da empresa. O horizonte do planejamento é para os próximos 10 anos, sendo que a última versão do plano estratégico foi feita com auxílio de uma consultoria no ano de 2007 . No plano estratégico desenvolvido foram criados os caminhos estratégicos que iriam suportar a empresa no horizonte de 10 anos. A partir desses caminhos, a cada ano, surgem diversas iniciativas possíveis, que potencialmente podem dar origem a um ou mais projetos, como por exemplo, ser o líder de mercado no Brasil.

Existe uma metodologia para prospectar as iniciativas que ainda não são projetos. Esta metodologia começa com a geração de iniciativas nas unidades de negócio através de um modelo que relaciona a meta, qual a ambição para os mercados interno e externo, quais são as diretrizes e quais são as plataformas chave de cada unidade de negócio. Identificada uma 
possível iniciativa, são levantados os ativos e capacitações necessários para a realização da iniciativa. Esta análise é similar a uma análise Strenghts Weaknesses, Opportunities and Threaths - SWOT, onde são observados os pontos fortes, as fraquezas, as lacunas críticas (ameaças) e as melhorias possíveis (oportunidades). A cada ano esta análise se repete dentro das áreas da empresa, verificando se existem novos caminhos ou direcionamentos a partir dos quais podem surgir novas iniciativas.

As áreas da empresa então preenchem um formulário padrão onde são colocadas as estimativas de grosso modo para cada iniciativa sugerida. Por exemplo: o caminho estratégico é atuar para competir como guerrilha; a iniciativa é atuação de guerrilha; o impacto é um aumento de $10 \%$ na fatia de mercado; tem alguma restrição?; tem algum risco? Para todas as iniciativas é preenchido um documento conhecido como "escopo mínimo".

Então as iniciativas são posicionadas em relação à aderência em relação aos processos existentes da empresa e o valor estratégico, conforme mostra a figura 1. Com a estimativa inicial (escopo mínimo) feita, para as iniciativas estratégicas é olhado o crescimento e rentabilidade; para os projetos plataforma ou capacitadores é observado como eles atacarão as restrições e/ou riscos.

Iniciativas que tem aderência e baixo valor estratégico são classificadas como diretriz funcional. Essas iniciativas são gerenciadas diretamente pelas áreas, com apoio apenas metodológico do Project Management Office - PMO Estratégico da empresa. As iniciativa classificadas como rotina/meta tem baixo valor estratégico e alta aderência aos processos existentes. Numa outra posição, as iniciativas são classificadas como ruptura de conhecimento, com alto valor estratégico e baixa aderência aos processos existentes. As iniciativas de alto valor estratégico e alta aderência aos processos existentes são classificadas como alto valor estratégico. Após o posicionamento das iniciativas pode ocorrer a fusão de iniciativas menores que podem formar uma iniciativa complexa que fica posicionada no quadrante estratégico. 


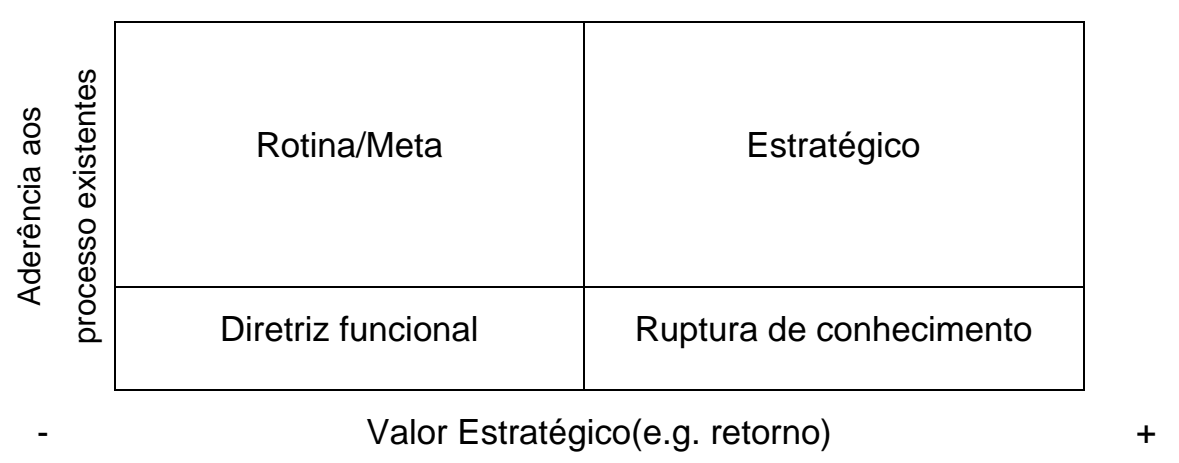

Figura 3 - Matriz de posicionamento de iniciativas da empresa 1

Fonte: Elaborada pelo autor

A partir daí é montada uma matriz de priorização. Esta matriz associa as iniciativas mapeadas das unidades com o respectivo caminho estratégico mais pertinente. Cada caminho estratégico tem um peso e são atribuídas notas para cada iniciativa em função da contribuição que ela traz para as metas de curto prazo do presidente da empresa. Com isso é possível balancear metas/objetivos de curto prazo (metas do presidente) e longo prazo (caminhos estratégicos).

O modelo de filtragem das iniciativas não é impositivo, ele apenas dá apoio para a tomada de decisão. O gestor tem liberdade de decisão se irá fazer ou não um determinado projeto. Dentro de um projeto estratégico pode existir um ou mais projetos de investimento. Estes projetos não são acompanhados pelo PMO Estratégico. Outra unidade da empresa faz esse acompanhamento. Para o projeto estratégico, o PMO garante o custo de implementação do projeto como desembolso futuro. Se houver a necessidade de algum investimento num projeto estratégico, ele deve passar por um Estudo de Viabilidade Técnico-Econômica - EVTE e este investimento é então acompanhado por outra diretoria.

A empresa classifica três tipos iniciais de projetos: estratégico, seis-sigma e rotina. Se o projeto for considerado estratégico, ele deve ser gerenciado segundo a metodologia de gestão de projetos. Se a origem é relacionada a algum problema, oportunidade sem causa conhecida, ele é tratado como um 
seis-sigma. Se o projeto é conhecido e mandatório ele é tratado como rotina. Estas classificações não são estanques, podendo surgir um projeto estratégico dentro de um projeto seis-sigma, ou vice-versa.

\subsubsection{Estratégias de implantação}

A diferença entre os projetos condiciona a forma de gestão. Um projeto estratégico exige mais gestão, mais bom senso, maior formalidade nas técnicas de gestão de projetos. Um projeto seis-sigma é mais técnico. Um dos requisitos para gerenciar um projeto estratégico é que o gerente de projetos tenha dedicação integral ao projeto.

Após esta filtragem das iniciativas, para cada uma dessas iniciativas que foram consideradas como projetos estratégicos é montado um master-plan, que passa a ser o contrato formal de aprovação do projeto. A complexidade do projeto é verificada quando se monta o escopo do projeto durante a execução do master-plan. Na fase anterior ao master plan o objetivo final é entendido, mas ainda não se sabe como chegar lá. O grau de incerteza está relacionado aos riscos identificados para o projeto.

A partir da aprovação do Master-Plan é feito o detalhamento. É estruturada a maneira como os indicadores técnico e financeiro do projeto serão acompanhados e medidos. Em seguida é montado o cronograma do projeto, onde é feito o detalhamento das atividades em durações inferiores a 15 dias. As checagens do projeto são quinzenais e são montados relatórios mensais de acompanhamento. O que se verifica na programação do projeto são as entregas.

Independentemente do projeto, a metodologia a ser seguida é sempre a mesma. No entanto, a forma de gestão pode ser diferente conforme a classificação do projeto em programa ou projeto. A diferenciação entre programa e projeto utilizada pela empresa é que os projetos estão associados a um objetivo único e claro.

Para todos os projetos ou programas é exigido um mínimo de formalidade através de checagens mensais no Comitê do Projeto, checagens quinzenais com o PMO, checagens semanais do dono com sua equipe de trabalho, uma 
checagem mensal com o patrocinador. Existem formas diferentes de gerenciar um programa e um projeto. Um projeto terá um cronograma e um arquivo no Sistema de Gestão de Projetos - SISGEP. Um programa terá vários cronogramas e vários SISGEPs e os pilares do projeto podem ser geridos individualmente com cada dono respectivo.

Quem define a forma de gerenciamento como programa ou projeto é o PMO Estratégico em conjunto com o patrocinador. O patrocinador tem a liberdade de abrir ou não o detalhamento de um pilar, conforme prefira gerenciar de forma mais ou menos agregada. No entanto, o PMO estratégico pode achar mais interessante do ponto de vista de gestão e acompanhamento abrir mais detalhes nos pilares, desde que seja possível possibilitar a visão mais agregada pedida pelo patrocinador.

Outra opção de escolha do patrocinador é não fazer a checagem de todos os pilares do projeto num mesmo momento. Num dia ele pode preferir checar um pilar, em outro dia um outro, e num outro dia ele pode querer ver todos em conjunto. Por exemplo, na reunião corporativa, o patrocinador precisará apresentar a visão do todo. Existem também projetos que têm seus próprios PMOs, ou Controllers. Nestes, o PMO Estratégico pode checar o projeto diretamente com este controller do dia-a-dia do projeto. Existe uma preocupação em garantir essa liberdade de forma de gestão aos projetos para permitir mais flexibilidade e ao mesmo tempo permear a noção de que a disciplina da metodologia seja útil.

É prática corrente na empresa a montagem de protótipos para projetos considerados de escopo amplo. O piloto pode nascer como uma fase do projeto. Por exemplo, ao iniciar o projeto Base da Pirâmide, no alinhamento de expectativas com o patrocinador do projeto foi perguntado se ele teria alguma área específica que ele gostaria de fazer um piloto. Como resposta, o patrocinador poderia indicar o sul do Brasil, pois a fatia de mercado naquela região é ruim. Poderia ocorrer também do patrocinador pedir uma proposta de piloto para o PMO Estratégico.

No entanto, o patrocinador também tem a liberdade de não fazer um piloto e seguir direto para uma escala mais ampla. Nestes casos, o PMO alerta o 
patrocinador sobre os riscos de não fazer um piloto, pois muitas coisas estarão sendo feitas e não será possível fazer uma avaliação intermediária no projeto quanto à aderência do que está sendo feito com a operação.

Com relação ao tratamento das contingências dos projetos, o PMO estratégico, por ser relativamente recente dentro da empresa, não tem condições de avaliar se uma determinada duração ou custo atribuído a uma atividade do projeto é viável ou não. É observado que os donos de projeto experientes colocam um fator de proteção razoável em seus orçamentos e prazos. A razão disso seria a falta de competência atual para orçar atividades de um projeto, ou ainda a baixa maturidade da empresa neste quesito. Para tentar contornar essa questão a empresa exige que o desdobramento das atividades no WBS chegue a atividades de no máximo 15 dias. No entanto, dentro desses 15 dias, o PMO Estratégico não sabe quando há de espaço de contingenciamento. A questão de urgência do projeto é tratado nas fases de classificação das iniciativas. Todos os projetos tem uma equipe em tempo integral e um representante do PMO alocado.

\subsubsection{Critérios de sucesso}

Os projetos estratégicos podem não ter ganhos de captura financeira (receita, custos). Os critérios de sucesso dos projetos estratégicos são uma combinação de métricas: cronogramas físico e financeiro do projeto, indicadores técnicos e indicadores financeiros.

A cobrança destas métricas está inserida no sistema de cobrança anual de resultados da empresa. São definidas cinco metas para o gerente de projeto. Uma delas vem do presidente (para a empresa como um todo), outra vem do patrocinador do projeto, e as outras três metas vêm do cronograma físicofinanceiro e dos indicadores de execução do projeto (técnico e captura financeira). Os projeto têm seus ciclos de vida definidos para abranger uma fase final de avaliação de resultados para que seja possível fazer a medição dos indicadores técnicos e de captura financeira do projeto.

Em relação ao peso atribuído aos indicadores de sucesso dos projetos, a empresa trata todos de maneira uniforme, com pesos iguais. São 
acompanhados os desvios dos indicadores do projeto. Quando houver um desvio do indicador é preenchido um documento conhecido como "R3G", que registra a identificação e o tratamento dado às anomalias do projeto. $\mathrm{O}$ objetivo é voltar o indicador para o plano original. Se houver uma necessidade de alterar o indicador em função de algum fato inesperado que pode ser uma oportunidade de aumento da captura, o gestor do projeto deve fazer uma solicitação de mudança que passa por um fluxo formal de aprovação.

No entanto, olhando do ponto de vista dos incentivos de remuneração, existem pesos sobre os critérios para recebimento dos bônus. Até $80 \%$ da meta do gestor pode estar atribuída aos projetos estratégicos, $10 \%$ é o patrocinador, $10 \%$ é o presidente. Para um ano específico, dos $80 \%$ relacionados aos projetos, 50\% é ligado ao cronograma físico e ao orçado versus realizado. Por exemplo, num projeto pode-se ter $60 \%$ das metas voltadas para atendimento do cronograma físico, 30\% para atendimento de entregas prioritárias e o restante para atendimento do custo orçado.

De maneira geral a empresa foca os incentivos de remuneração para os projetos no atendimento do cronograma físico e do orçamento. Os indicadores técnicos acabam não sendo avaliados. A visão predominante é que o gestor do projeto deve estar focado na implementação do projeto. $\mathrm{Na}$ ferramenta de acompanhamento desenvolvida pela empresa, conhecido como SISGEP, existe uma avaliação final de projeto, que analisa o desempenho do projeto em termos da gestão e em termos dos indicadores técnicos e de captura financeira. Para cada elemento analisado nesta avaliação é dada uma nota e é obtida uma nota final do projeto. Na nota final relativa à gestão do projeto é a média das notas atribuídas a cada um dos itens sob análise. Na nota final relativa aos indicadores técnicos e de captura financeira são atribuídos pesos e obtida uma média ponderada ao final.

Não há nenhum indicador nos projetos relativo aos possíveis impactos relativos à equipe do projeto. Em relação aos indicadores relacionados à preparação para o futuro, a empresa não tem uma métrica atual. Em projetos de inovação existe uma preocupação em relação a isso. $\mathrm{Na}$ linguagem da 
empresa, a interpretação dada é o que se pode levar de bom se o projeto não tiver sucesso.

A tabela 8 mostra como a Empresa 1 trata o início dos projetos, seus critérios de sucesso e as estratégias de gestão de projetos.

\begin{tabular}{|c|c|}
\hline Item & Empresa 1 \\
\hline $\begin{array}{l}\text { Identificação do } \\
\text { tipo de projeto }\end{array}$ & $\begin{array}{l}\text { A empresa } 1 \text { categoriza seus projetos em estratégico, seis-sigma e rotina. A classificação } \\
\text { baseia-se no retorno e na aderência aos processos existentes. }\end{array}$ \\
\hline $\begin{array}{l}\text { Critérios de } \\
\text { sucesso e } \\
\text { fracasso }\end{array}$ & $\begin{array}{l}\text { A empresa } 1 \text { define as expectativas gerenciais nas seguintes dimensões: cumprimento do } \\
\text { cronograma e orçamento, atendimento de metas operacionais e metas } \\
\text { econômico/financeira (captura financeira). Todas as métricas são verificadas dentro do } \\
\text { prazo do projeto. }\end{array}$ \\
\hline Organização & $\begin{array}{l}\text { Projetos estratégicos seguem metodologia específica de gestão de projetos definida pela } \\
\text { empresa. O gerente ou líder do projeto tem dedicação exclusiva. }\end{array}$ \\
\hline $\begin{array}{l}\text { Gestão de } \\
\text { requisitos }\end{array}$ & $\begin{array}{l}\text { As incertezas relacionadas ao levantamento dos requisitos do projeto não são avaliadas } \\
\text { pela empresa. No entanto é prática comum o uso de protótipos de mercado para avaliar } \\
\text { melhor os riscos de um projeto inovador de resultado incerto. }\end{array}$ \\
\hline $\begin{array}{l}\text { Criação e } \\
\text { Construção do } \\
\text { produto }\end{array}$ & $\begin{array}{l}\text { Por se tratarem de projetos estratégicos, muitas atividades estão sendo feitas pela primeira } \\
\text { vez na empresa. No entanto, não são previstos ciclos de iteração ou verificada a } \\
\text { necessidade de prorrogar o momento de congelamento do projeto do produto. A empresa } 1 \\
\text { pratica a montagem de protótipos nos projetos estratégicos. Os resultados obtidos no } \\
\text { protótipo realimentam um novo ciclo de projeto de produto }\end{array}$ \\
\hline $\begin{array}{l}\text { Re- } \\
\text { planejamento do } \\
\text { projeto }\end{array}$ & $\begin{array}{l}\text { Os projetos são monitorados periodicamente a cada } 15 \text { dias. Deste monitoramento podem } \\
\text { surgir revisões de projeto que necessitem mudanças. }\end{array}$ \\
\hline
\end{tabular}

Tabela 8:Abordagem de gestão de projetos - Empresa 1 


\subsection{Estudo de caso 2}

Empresa do setor siderúrgico, líder de mercado e um dos maiores produtores mundiais de aço. Tem 107 anos de existência, possui 37 mil colaboradores e opera em 13 países.

No início dos anos 1980, o grupo empresarial produzia um milhão de toneladas de aço por ano em cinco unidades. Naquela época a empresa começou seu processo de internacionalização. Em 2002, o grupo empresarial se tornou o maior produtor de aços longos das Américas, contabilizando um crescimento no período de 1980-2002 de 800\%, com nove milhões de toneladas em 2002. Em 2007, a empresa produziu 18 milhões de toneladas de aço.

O faturamento do grupo empresarial em 2007 chegou a $\$ 34,184$ bilhões de reais, com receita líquida de $\$ 30,6$ bilhões de reais. A divisão do faturamento da empresa tem as seguintes origens e contribuições: 40\% mercado internoBrasil; 7\% exportações originadas no Brasil; 33\% Estados Unidos e Canadá; 11\% América Latina; 9\% Europa. O lucro líquido em 2007 foi de 4,3 bilhões de reais.

Em 2006, as unidades de negócio da empresa localizadas no Brasil tiveram os seguintes resultados:

\begin{tabular}{|l|c|c|c|}
\hline \multicolumn{1}{|c|}{ Unidade de negócio } & $\begin{array}{c}\text { Receita } \\
\text { Líquida }\end{array}$ & $\begin{array}{c}\text { Lucro } \\
\text { líquido }\end{array}$ & $\begin{array}{c}\text { Rentabilidade } \\
\text { Patrimônio líquido }\end{array}$ \\
\hline Aços Longos & $5.819,8$ & $1.002,9$ & $31,6 \%$ \\
\hline Aços Planos & $3.068,9$ & 743,8 & $21,7 \%$ \\
\hline Aços Especiais & 960,1 & 248,2 & $38,0 \%$ \\
\hline
\end{tabular}

Tabela 9: Unidades de negócio - Empresa 2 - Valores em milhões de $R \$$ Fonte: Relatório Anual da empresa 2007 
As operações da empresa são constituídas pelas seguintes unidades:

- 42 unidades siderúrgicas

- 14 unidades de transformação

- 87 unidades de corte e dobra de aço

- 4 centros de serviço de aço plano

- 75 unidades comerciais

- 32 unidades de coleta e processamento de sucata

- 4 áreas de extração de minério de ferro

- 2 unidades de produção de ferro-gusa sólido

- 2 terminais portuários privados

Além dessas unidades de operação, o grupo possui controle acionário de empresas coligadas que abrangem as seguintes unidades operacionais:

- 10 unidades siderúrgicas

- 4 unidades de transformação

- 3 unidades comerciais

Operando como joint ventures, o grupo tem as seguintes unidades operacionais:

- 2 unidades siderúrgicas

- 4 unidades de transformação

- 1 unidade de corte e dobra de aço

Os diferenciais competitivos, segundo dados da empresa, são a tecnologia atualizada, o custo de produção competitivo, os processos produtivos diversificados, a participação de mercado relevante nos países onde opera, o acesso a bolsas de valores internacionais e a experiência na reversão de resultados de empresas adquiridas.

A empresa possui um sistema corporativo global que consolida as melhores práticas do grupo. Implantado em 2002, o sistema serve de auxílio para os 
gestores e equipes garantirem o alinhamento estratégico das iniciativas da empresa. O sistema estrutura e padroniza políticas, diretrizes, melhores práticas e indicadores de desempenho. O sistema acumulou, até 2007, cerca de 800 melhores práticas em todos os processos.

A figura 4 mostra a estrutura do sistema.

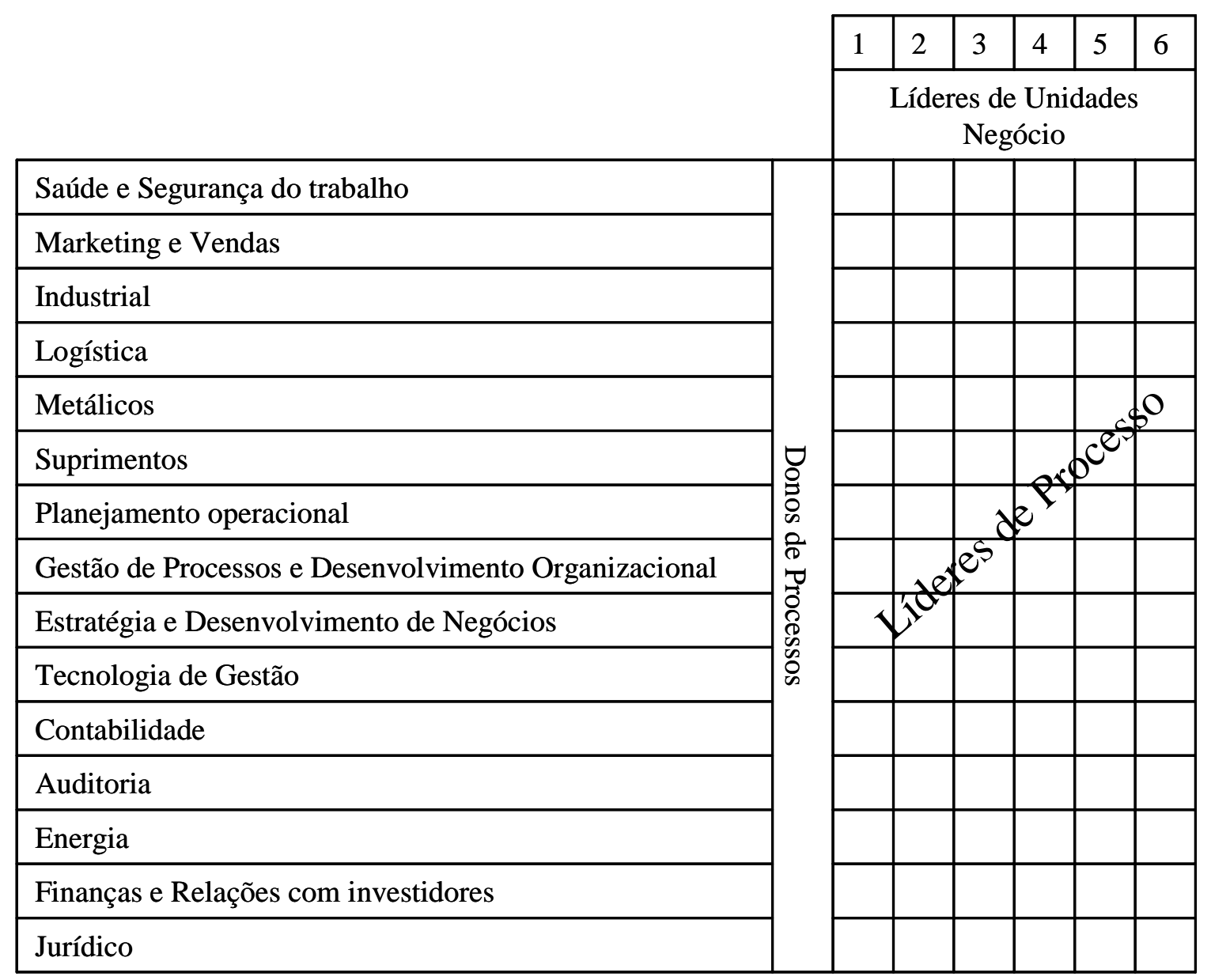

Figura 4 - Sistema Corporativo Global

Fonte: Adaptado do original contido no Relatório Anual da empresa - 2007

Cada macro processo - Marketing, Tecnologia de gestão, etc - é coordenado por um Dono de Processo, que atua com líderes de processo das unidades de negócio nos diversos países onde o grupo empresarial está presente.

A unidade da empresa que foi objeto deste estudo é localizada na região sul do Brasil. Originalmente esta unidade de negócio era uma sociedade de economia mista controlada pelo governo estadual local. A empresa adquiriu 
esta unidade nos anos 1990 através do Programa de Privatização do Governo Federal.

A compra desta unidade marcou a entrada da empresa num novo negócio que tem como principal cliente a indústria automobilística. A empresa investiu cerca de 100 milhões de dólares na unidade adquirida para liquidar débitos, atualizar equipamentos e tecnologias, treinar operadores e ajustar as estruturas gerencial e comercial.

Os resultados dos investimentos feitos puderam ser observados no aumento da produção. Antes dos investimentos a unidade de negócio produzia 141 mil toneladas anuais de aço e 100 mil toneladas de laminados. Doze anos depois, os mesmos itens atingiram respectivamente, 345 mil e 383 mil toneladas anuais. A capacidade produtiva da unidade é de 500 mil toneladas por ano de aço bruto. A unidade tem certificação de qualidade ISO 9002, já ganhou o Prêmio Nacional da Qualidade e tem também o certificado ISO 14000 , de controle ambiental.

\subsubsection{Início dos projetos}

Os projetos na unidade estudada são originados no planejamento estratégico da unidade. A unidade tem autonomia para criar seu próprio planejamento estratégico a partir de diretrizes estabelecidas pelo escritório central da empresa. As iniciativas sugeridas são validadas no final de cada ano.

O plano estratégico define uma série de metas que são monitoradas através de métricas pré-estabelecidas para a célula, para a área ou para a usina como um todo. Por exemplo, uma dessas metas pode ser um determinado nível aceitável de reclamação de clientes, de tal forma que qualquer número acima da meta estabelecida pode gerar um conjunto de iniciativas para atacar o problema. As iniciativas pensadas para atacar o problema identificado são analisadas e priorizadas por um time de planejamento estratégico, constituído pela alta liderança da planta. A avaliação feita por esse time para definir qual iniciativa irá adiante leva em conta a disponibilidade de recursos, a prioridade da iniciativa, a existência de condições para trabalhar na iniciativa no momento, entre outros fatores. 
Existe uma lista de checagem pré-definida, mas há liberdade para se acrescentar novos critérios nas reuniões de avaliação. Para cada tipo de projeto existem reuniões estruturadas conforme o grau de abrangência do projeto. Nessas reuniões são observadas a quantidade de interações com vários gestores e a necessidade de acompanhamento centralizado do projeto.

Os projetos são classificados em estratégicos e não estratégicos. Para os projetos considerados estratégicos existe uma metodologia a ser seguida e acompanhada pela área de tecnologia de gestão. Há um limite de até 10 projetos que podem ser encaixados na categoria de estratégicos a cada ano. Este limite é definido em função da capacidade da área de tecnologia de gestão para assessorar o planejamento e acompanhamento do projeto.

Para os demais projetos, não há um acompanhamento centralizado. Cada projeto classificado como não estratégico é planejado e acompanhado diretamente pela área a qual o projeto pertence.

A avaliação feita por esse time estratégico serve como um pré-filtro que diminui bastante a quantidade de iniciativas que irão adiante. Aquelas iniciativas que seguem adiante são formalizadas através de um termo de abertura de projeto. Este termo contém o número e nome do coordenador, o escopo do projeto, os recursos necessários, , as metas consensuadas com as partes interessadas e o investimento a ser feito.

\subsubsection{Estratégias de implantação}

Para os projetos estratégicos, a empresa tem sua própria metodologia de gestão de projeto e um software próprio para apoio. Apenas os projetos considerados estratégicos seguem obrigatoriamente essa metodologia. A metodologia é baseada no PMBOK (2004), sendo que a gestão de riscos e a gestão da comunicação são considerados os elementos menos formalizados no planejamento de projetos da unidade.

Para os projetos, estratégicos ou não, a reunião inicial do projeto é o momento em que são definidas exigências específicas para a gestão dos projetos. Neste momento é decidido o grau de formalização e detalhamento 
na montagem dos cronogramas de projeto e a forma e periodicidade de acompanhamento.

A equipe de gerenciamento dos projetos é sempre compartilhada em função da limitação de recursos na unidade. Quando o projeto está sendo escolhido para compor o portfólio da unidade, a alocação do gerente de projeto e eventual equipe é feita levando em conta a disponibilidade de dedicação desta equipe para a gestão do projeto. Em projetos estratégicos procura-se atribuir equipes que tenham mais tempo disponível para se dedicarem à gestão dos projetos.

Os projetos são acompanhados em intervalos máximos de 30 dias para aferição dos indicadores de tempo e custo e projeção dos indicadores operacionais e financeiros. As reuniões de acompanhamento dos resultados são formais e são precedidas pelo envio de um relatório resumo para todas as partes envolvidas com os principais pontos a serem discutidos. No entanto, as equipes gerenciais têm liberdade para programarem reuniões de acompanhamento em intervalos menores. É usual se observar reuniões semanais em nível da equipe do projeto.

Não há nenhuma classificação quanto ao grau de inovação que um projeto pode trazer para a empresa e os eventuais riscos associados a um produto novo não são formalmente incorporados ao planejamento dos projetos.

Em termos de urgência, os projetos de investimento têm mais pressão de tempo. Nos demais projetos não há um rigor em relação ao cumprimento do prazo. Esse menor formalismo é compensado pelo caráter anual de tratamento dos projetos. Ao final do ano é apresentada a situação de cada projeto e os resultados obtidos. Esses pontos são analisados e são tomadas decisões pela continuidade ou não do projeto.

Em relação à tecnologia, a empresa é geralmente conservadora em suas abordagens. É dada preferência a tecnologias, processos e metodologias já experimentadas. 


\subsubsection{Critérios de sucesso}

Os critérios de sucesso dos projetos são focados principalmente nos impactos para o negócio e métricas operacionais. As métricas de eficiência relativas ao atendimento do prazo e do custo tem pesos diferentes. O custo é sempre um item importante a ser monitorado. O prazo é importante para os projetos que envolvem investimentos, mas pouco relevante para os projetos que não envolvem investimentos.

A pouca importância dada ao prazo do projeto ocorre porque os critérios de sucesso dos projetos seguem um padrão de anualização dos resultados. Desta forma, um projeto que tenha prazo previsto acima de um ano, é geralmente compartimentado para ser possível aferir as metas de benefícios para o negócio e os benefícios operacionais no intervalo de um ano.

As definições das métricas são feitas nas reuniões iniciais do projeto quando do fechamento do termo de abertura do projeto. O acompanhamento das métricas de tempo e custo é feito formalmente em base mensal. As métricas de negócio e operacionais são normalmente medidas nos últimos três meses do ano.

Os critérios de sucesso dos projetos não levam em conta nenhum critério de impacto na equipe do projeto. No entanto, existe a preocupação, já mencionada, de dimensionar um tempo adequado para que as equipes possam compartilhar o trabalho de gestão de projetos com suas atividades de rotina.

Existem também algumas métricas qualitativas que são definidas para 0 projeto. Algumas dessas métricas são avaliadas ao final do ano quando são feitas sessões de lições aprendidas para cada projeto.

A tabela 10 apresenta como a Empresa 2 trata o início dos projetos, seus critérios de sucesso e as estratégias de gestão de projetos. 


\begin{tabular}{|c|c|}
\hline Item & Empresa 2 \\
\hline $\begin{array}{l}\text { Identificação do } \\
\text { tipo de projeto }\end{array}$ & $\begin{array}{l}\text { A empresa } 2 \text { categoriza seus projetos em estratégicos e não estratégicos. Todos os } \\
\text { projetos são internos à unidade analisada. }\end{array}$ \\
\hline $\begin{array}{l}\text { Critérios de } \\
\text { sucesso e } \\
\text { fracasso }\end{array}$ & $\begin{array}{l}\text { A empresa } 2 \text { define as expectativas gerenciais nas seguintes dimensões: cumprimento do } \\
\text { cronograma e orçamento, atendimento de metas operacionais e metas } \\
\text { econômico/financeira. Estas métricas são anualizadas para projetos que tenham mais de } \\
\text { um ano. }\end{array}$ \\
\hline Organização & $\begin{array}{l}\text { Projetos estratégicos seguem metodologia específica de gestão de projetos definida pela } \\
\text { empresa. O gerente ou líder do projeto compartilham seu tempo na gestão do projeto com } \\
\text { os trabalhos rotineiros. }\end{array}$ \\
\hline $\begin{array}{l}\text { Gestão de } \\
\text { requisitos }\end{array}$ & $\begin{array}{l}\text { As incertezas relacionadas ao levantamento dos requisitos do projeto não são avaliadas } \\
\text { pela empresa. }\end{array}$ \\
\hline $\begin{array}{l}\text { Criação e } \\
\text { Construção do } \\
\text { produto }\end{array}$ & $\begin{array}{l}\text { Por se tratarem de projetos internos e de processos conhecidos, a previsibilidade dos } \\
\text { projetos não traz preocupações com ciclos de iteração ou a necessidade de prorrogar o } \\
\text { momento de congelamento do projeto do produto. }\end{array}$ \\
\hline $\begin{array}{l}\text { Re- } \\
\text { planejamento do } \\
\text { projeto }\end{array}$ & $\begin{array}{l}\text { Os projetos são monitorados periodicamente a cada } 30 \text { dias. Deste monitoramento podem } \\
\text { surgir revisões de projeto que necessitem mudanças. }\end{array}$ \\
\hline
\end{tabular}

Tabela 10: Abordagem de gestão de projetos - Empresa 2 


\subsection{Estudo de caso 3}

A empresa 3 pertence ao setor financeiro. A história da empresa começou nos anos 1940, com outro nome, e nas décadas seguintes a empresa cresceu através da incorporação de outras instituições, quando através de mais uma fusão, a empresa passou a ter o nome atual.

Em 2007, o controle da empresa 3 era realizado por uma holding que agregava outras duas empresas além da empresa 3. As ações da empresa são negociadas na BOVESPA no Brasil e na NYSE nos Estados Unidos. A figura 5 ilustra a composição acionária da holding (a empresa 3 é o Banco Comercial).

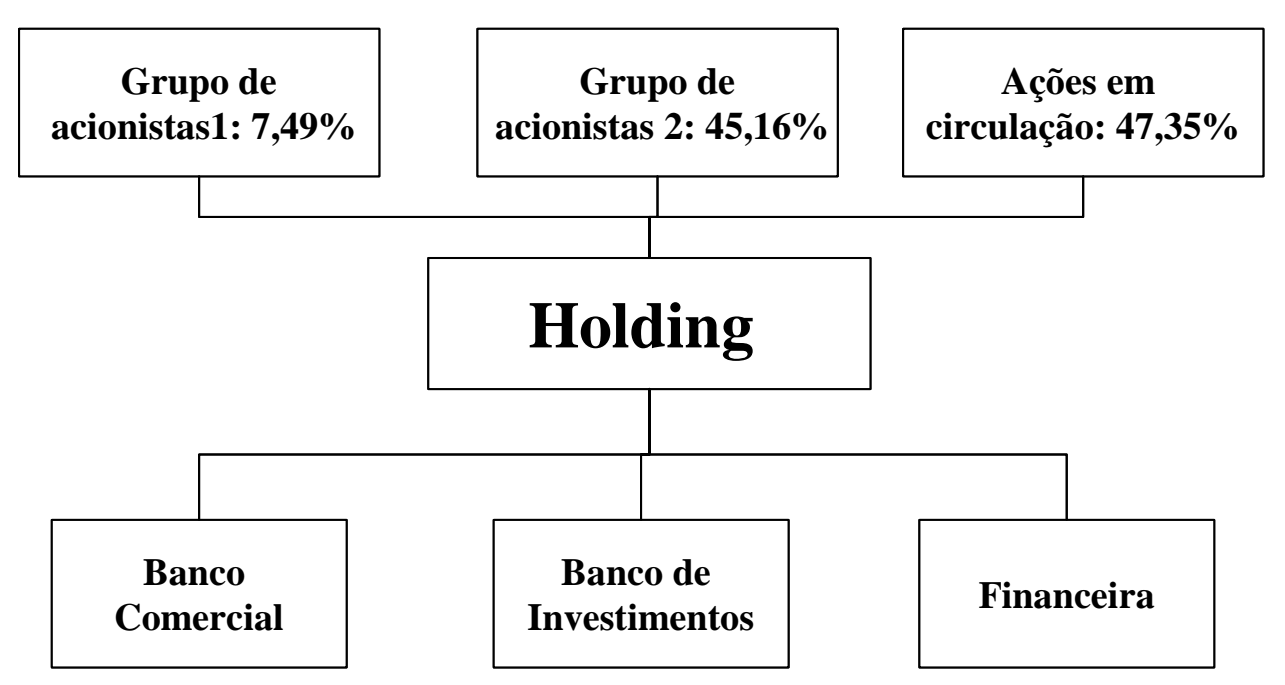

Figura 5: Composição acionária da Holding - Empresa 3

Fonte: Relatório Anual da Empresa 3 - 2007

Ainda em 2007, a empresa reportou ativos de 327 bilhões de reais, dos quais 221,5 bilhões de reais são administrados e os restantes 78 bilhões de reais são depósitos. No mesmo ano de 2007, a empresa reportou 2.594 agências no Brasil, 11,2 milhões de correntistas e uma carteira de empréstimos de 137,7 bilhões de reais. A empresa encerrou o ano de 2007 com 66.442 pessoas em seu quadro de pessoal.

A estratégia de crescimento, desde a metade dos anos 1990, foi focada em aquisições e parcerias nos diversos setores de atuação da empresa: varejo 
bancário, atuação internacional, ativos administrados, banco de investimento, crédito ao consumidor, cartões de crédito, crédito imobiliário e resseguros.

As áreas de atuação da holding estão divididas nas empresas controladas que atuam em segmentos distintos: banco comercial, banco de investimento e financeira. O foco de análise deste trabalho é o banco comercial, que atua nas seguintes áreas: banking, cartões correntistas, seguros/previdência/capitalização e gestão de fundos e carteiras.

A empresa atua com produtos e serviços bancários para diversos perfis de clientes, incluindo pessoas físicas e microempresas, pequenas empresas, médias empresas, poder público, investidores institucionais, pessoas físicas de alta renda e clientes com elevado patrimônio financeiro.

Além disso, a empresa também atua na administração de negócios de underwriting, custódia, corretagem de valores mobiliários, cartões de crédito, consórcios, seguros, capitalização e previdência privada, financiamento de veículos e operações de financiamentos para não-correntistas das classes econômicas C e D.

As vantagens competitivas da empresa são escala, capilaridade, processos e tecnologia. A escala e capilaridade das operações da empresa pode ser observada na rede de 3.528 agências bancárias e postos de serviços no final de 2007, com atuação em todo o território do Brasil. A atenção aos processos pode ser observada nos 150 processos certificados no conjunto de normas ISO 9000. Na área tecnológica a empresa investe continuamente para aprimoramento da qualidade e da segurança das operações. Em 2007, foram investidos cerca de R\$2 bilhões em tecnologia.

O modelo de gestão da empresa se baseia na interatividade entre as áreas e na troca de informações e fortalecimento das sinergias. O funcionamento deste princípios ocorre através de comitês estratégicos que permeiam a empresa e constituem estruturas formais de governança corporativa. Uma das formas de disseminação das informações entre as diversas camadas hierárquicas da empresa é um programa de ação gerencial. Trata-se de uma ferramenta de gestão que define prioridades, estabelece objetivos, acompanha desempenhos e remunera pelos desempenhos. 


\subsubsection{Início dos projetos}

A origem dos projetos na empresa vem de necessidades regulatória, operacional, negócio e tecnologia. Não há um encadeamento claro entre o planejamento estratégico e os projetos. A seleção dos projetos é feita conforme uma justificativa de retorno e esforço necessário.

Não existe uma análise formal da complexidade e incertezas envolvidas nos projetos. Segundo um dos entrevistados, apesar de não haver formalidade, existe uma análise prévia que classifica os projetos em duas grandes categorias. Projetos simples são resolvidos internamente, sem reuniões de alto nível. Projetos complexos são agendadas reuniões com diretores e superintendentes para alinhamento prévio antes da tomada de decisão de seguir adiante ou não.

A empresa não utiliza nenhum referencial para classificação da complexidade e incerteza dos projetos. Há uma dependência do estilo gerencial do responsável pelo projeto. Segundo um dos entrevistados, a complexidade é medida pela quantidade de grupos de pessoas envolvidas. Quando há um grupo externo, como uma consultoria externa, a complexidade aumenta. Quando há mais de uma área usuária e a necessidade de participação de uma área de infra-estrutura, aumenta a complexidade do projeto.

Além disso, as disputas políticas aumentam a complexidade dos projetos. Por exemplo, num projeto de data warehouse, no início em 1995, apesar de haver três superintendências envolvidas nos trabalhos, o projeto estava sem rumo. Cada superintendência puxava para si algumas responsabilidades e o projeto ficava sem dono.

Outro grau de complexidade é inerente à inovação. A inovação traz uma série de dúvidas e uma série de necessidades em termos de treinamento e capacitação. No caso do projeto data warehouse, a inovação adicionava complexidade ao projeto em função de não existirem pessoas capacitadas dentro da empresa e nas consultorias externas. Neste último, mesmo tendo feito alguns projetos relacionados ao tema, o porte deste projeto de data warehouse era algo inédito para essas consultorias. 
$\mathrm{Na}$ colocação de um dos entrevistados sobre este projeto se percebe a preocupação nas implicações gerenciais de um projeto que gere um resultado inovador.

“Este projeto representou a implantação de uma inovação, algo não muito usual na empresa. A estratégia usual da empresa é seguir o inovador e não ser o inovador. As complexidades inerentes de projetos inovadores são a falta de conhecimento do pessoal da consultoria, falta de experiência de mercado, falta de suporte. Tais pontos geram uma dificuldade enorme para estruturação do projeto, pois é preciso ter uma capacitação conjunta entre a equipe interna de desenvolvimento e a equipe da consultoria, além de atendimento de uma expectativa de entregar algo que agregasse valor."

A complexidade reflete o desafio da tecnologia nova. No caso do projeto de data warehouse, a preocupação maior era a assimilação da tecnologia pelas equipes internas da empresa, com capacitação das pessoas para gerar independência das consultorias externas em projetos similares no futuro. A escala do projeto e o uso de uma nova tecnologia trouxeram problemas inéditos na implantação do projeto. Mais especificamente, no projeto de data warehouse surgiram problemas técnicos inéditos, para os quais eram acionados o fornecedor e as consultorias para buscar uma solução.

\subsubsection{Estratégias de implantação}

Não existe uma metodologia formal de gestão de projetos na empresa. A variação de abordagens e processos de gestão é grande dentro do universo de projetos da empresa. Por exemplo, projetos originados na área de Organizações e Métodos tem uma padronização de processos, com obrigatoriedade de apresentação de uma proposta para cada projeto, em que é descrito o escopo e apresentado um cronograma inicial. Em outras áreas, o processo é não formalizado e varia conforme o estilo gerencial dos líderes envolvidos. 
Um dos entrevistados descreveu uma estratégia de implantação derivada do reconhecimento das incertezas relativas aos objetivos de um projeto.

"Como o projeto envolvia várias áreas, foi feita uma avaliação inicial, com entrevistas com todos os gerentes e superintendentes. O objetivo da avaliação era mapear as equipes das áreas para identificar as pessoas mais adequadas para participar do projeto em cada uma das áreas envolvidas. Além disso, com a avaliação seria possível estruturar a equipe e saber com qual usuário fazer esse trabalho."

Outra estratégia descrita por um dos entrevistados para tratar projetos com muitas incertezas em relação aos requisitos é a utilização de quick-wins, ou seja, a concentração de esforços em partes do projeto que possam gerar resultados mais rapidamente e ajudar no entendimento das necessidades dos usuários do resultado do projeto.

Em relação ao grau de ritmo necessário ao projeto em função do tempo disponível, um dos entrevistados afirmou ser bastante comum atribuir o atendimento do prazo do projeto à consultoria contratada. A consultoria dá uma visão geral sobre os trabalhos a serem feitos e em seguida, na primeira e segunda semana, se trabalha na definição do escopo do projeto. Se estressa a consultoria neste período e depois durante todo o projeto acaba ficando o dito pelo não dito. A consultoria fica responsável pelo prazo e a empresa fica tentando esticar o escopo do projeto.

Num outro projeto referente a unificação de áreas de atendimento ao cliente - receptivo e ativo, um dos entrevistados descreveu a adoção de estratégias específicas de gestão do projeto, motivadas por um reconhecimento da complexidade envolvida no projeto. Neste projeto, o gestor tinha a percepção de que o prazo de sete meses do projeto tinha poucas chances de ser atendido.

As razões para essa percepção do entrevistado estão descritas nos seguintes pontos:

Primeiro, além da unificação das centrais receptivas e ativas, foi decidido mudar também o software de gestão destas operações. Seria um novo 
software, diferente dos outros dois existentes e em operação. O novo software era um pacote de mercado oferecido por uma empresa com pouca experiência no Brasil e com poucas pessoas com conhecimento sobre implantações do mesmo.

Segundo, a plataforma de telefonia também seria atualizada, o que envolvia a mudança da arquitetura do sistema de telefonia. Além disso, seria atualizada a forma de comunicação entre o software da gestão das centrais e a plataforma de telefonia. A comunicação a ser feita pelo software envolvia um volume de dados com escala inédita nas implantações já existentes do software pelo mundo.

Terceiro, os dois sistemas existentes eram responsabilidade de duas áreas diferentes e havia uma indefinição sobre qual área seria responsável pelo sistema unificado, o que acabava gerando desconfortos e ansiedades nas áreas em relação ao projeto.

No entanto, esta percepção do líder do projeto quanto aos riscos envolvidos não foi considerada pelos executivos da empresa e pela consultoria, responsáveis pela definição do prazo do projeto

Mesmo sem o reconhecimento da complexidade e das incertezas envolvidas, o líder do projeto teve a iniciativa de documentar formalmente as decisões sobre o escopo do projeto. De acordo com o entrevistado, logo no segundo mês do projeto, o responsável pelo monitoramento indicou a situação crítica do projeto quanto ao cumprimento do prazo combinado de sete meses. $O$ responsável pelo monitoramento era um profissional experimentado indicado pela empresa fornecedora do software.

Outro projeto descrito por um dos entrevistados ilustra os problemas gerados por um sub-dimensionamento das incertezas tecnológicas envolvidas.

"Uma expectativa inicial do projeto era que o novo sistema traria uma produtividade maior e que a customização seria pequena e fácil de ser feita, comparada à alternativa de desenvolvimento de software interno. No entanto, não foi isso que ocorreu. Para complicar, internamente a empresa não tinha capacidade suficiente para a demanda de customização gerada. Isto levou a 
uma mudança no oitavo mês do projeto, com a decisão de não fazer mais customizações no pacote do software adquirido, mas desenvolver aplicações em web internamente para suprir as necessidades".

Outro exemplo que ilustra a utilização de estratégias para minimizar riscos em projetos percebidos pelos gestores como tendo alto grau de inovação é a formação de grupos foco com usuários do resultado do projeto para definição e validação dos requisitos do produto a ser entregue. Também foi mencionado pelos entrevistados a utilização de análises comparativas para definir expectativas e métricas (benchmarkings) com instituições do mesmo setor no exterior.

Uma tentativa de organizar os projetos da empresa está ligada a uma iniciativa corporativa para instituir uma cultura de desempenho. $O$ objetivo principal deste programa, iniciado em 2005, é desenvolver um ambiente de trabalho estimulante e motivador que promova a participação dos funcionários para melhoria do negócio.

$\mathrm{Na}$ primeira fase, cada área identifica projetos de melhoria de suas atividades. Na segunda etapa, as áreas executivas irão eleger projetos de performance que envolvem outras áreas. Para os projetos nas áreas foi desenvolvida uma metodologia para executar os projetos de geração e implementação de idéias. Para os projetos que envolvem mais áreas, os diretores serão os patrocinadores e as equipes serão nomeadas pelos gestores das áreas.

\subsubsection{Critérios de sucesso}

Em relação aos critérios de sucesso, percebeu-se que os projetos são avaliados em critérios multi-dimensionais, mas não há um processo ou orientação formal sobre como fazer isso. Novamente, a definição dos critérios e métricas depende do estilo gerencial do executivo e do responsável pelo projeto.

Uma das métricas é o atendimento do que foi previsto em termos de escopo, prazo e custo. Outra medida percebida foi a preocupação com a capacitação 
da equipe interna para dar continuidade a novos projetos similares sem ajuda de uma consultoria externa.

Do ponto de vista do negócio, há expectativas de ganhos de produtividade em projeto centrados em melhorias internas e é sempre feito a valoração de ganhos para lançamento de novos produtos comerciais.

A dificuldade de definição de métricas quantitativas para algumas dimensões foi expressado pelos entrevistados. Por exemplo, num projeto interno de mudança de plataforma tecnológica das centrais de atendimento receptivo e ativo de clientes não foi estabelecida uma métrica quantitativa para avaliar a capacitação das equipes internas para desenvolverem projetos similares no futuro. No entanto, o gestor conseguiu fazer essa avaliação de forma qualitativa, pois problemas similares ao que gerou este projeto já estavam ocorrendo em outros lugares dentro da empresa e pessoas da equipe do projeto estavam conseguindo resolver estas outras situações sem precisar do apoio da consultoria.

Outro exemplo de dificuldade, ainda no mesmo projeto, foi a avaliação da melhoria de gestão de informações proporcionada pelo projeto. Havia uma percepção dentro das áreas usuárias de que a gestão de informações havia melhorado, mas, segundo descrição de um dos entrevistados, após o término do projeto, ainda foi dedicado mais um ano para explicação e entendimento das possibilidades de gestão das informações dentro das áreas usuárias.

A tabela 11 apresenta como a Empresa 3 trata o início dos projetos, seus critérios de sucesso e as estratégias de gestão de projetos. 


\begin{tabular}{|c|c|}
\hline Item & Empresa 3 \\
\hline $\begin{array}{l}\text { Identificação do } \\
\text { tipo de projeto }\end{array}$ & $\begin{array}{l}\text { A empresa } 3 \text { não categoriza formalmente seus projetos. No entanto, cada gestor de projetos } \\
\text { tem suas percepções quanto a complexidade e incerteza envolvida. Também não percebeu- } \\
\text { se uma comunicação efetiva destas percepções entre as partes interessadas. }\end{array}$ \\
\hline $\begin{array}{l}\text { Critérios de } \\
\text { sucesso e } \\
\text { fracasso }\end{array}$ & $\begin{array}{l}\text { A empresa } 3 \text { define as expectativas gerenciais nas seguintes dimensões: cumprimento do } \\
\text { cronograma e orçamento, atendimento de metas operacionais e metas } \\
\text { econômico/financeira. }\end{array}$ \\
\hline Organização & $\begin{array}{l}\text { Os projetos não seguem metodologia específica de gestão de projetos definida pela } \\
\text { empresa. Os gerentes ou líderes de projeto compartilham seu tempo na gestão do projeto } \\
\text { com os trabalhos rotineiros. }\end{array}$ \\
\hline $\begin{array}{l}\text { Gestão de } \\
\text { requisitos }\end{array}$ & $\begin{array}{l}\text { As incertezas relacionadas ao levantamento dos requisitos do projeto não são avaliadas } \\
\text { formalmente pela empresa. No entanto, percebeu-se entre os entrevistados, uma } \\
\text { preocupação com esta etapa da gestão dos projetos. Levantamentos iniciais nas áreas } \\
\text { envolvidas, utilização de grupos foco e utilização de pesquisas de mercado são evidências } \\
\text { observadas para minimizar os riscos do levantamento de requisitos em projetos complexos } \\
\text { e incertos. }\end{array}$ \\
\hline $\begin{array}{l}\text { Criação e } \\
\text { Construção do } \\
\text { produto }\end{array}$ & $\begin{array}{l}\text { Os eventuais ciclos de iteração ou a necessidade de prorrogar o momento de congelamento } \\
\text { do projeto do produto são estratégias observadas em projetos da organização. A utilização } \\
\text { de consultorias externas é uma outra abordagem para suprir a falta de competência interna } \\
\text { para o desenvolvimento de projetos. }\end{array}$ \\
\hline $\begin{array}{l}\text { Re- } \\
\text { planejamento do } \\
\text { projeto }\end{array}$ & $\begin{array}{l}\text { Não há uma periodicidade de atualização dos projetos. Cada projeto define seus intervalos } \\
\text { de controle. Na há formalidade de processo para controle de mudanças. }\end{array}$ \\
\hline
\end{tabular}

Tabela 11: Abordagem de gestão de projetos - Empresa 3 


\subsection{Estudo de caso 4}

Fundada na década de 1940 no Brasil, a empresa 4 atua no setor de mineração e está entre os líderes de mercado mundiais no setor. Os negócios da empresa abrangem pesquisa mineral, produção de minérios, siderurgia, logística e energia. A visão da empresa é:

"Ser a maior empresa de mineração do mundo e superar os padrões consagrados de excelência em pesquisa, desenvolvimento, implantação de projetos e operação de seus negócios." (Relatório de Sustentabilidade, 2007)

No negócio de produção de minérios, a empresa é a maior produtora mundial de minério de ferro e pelotas, matéria prima primordial da indústria siderúrgica. A empresa está entre as maiores produtoras de níquel, com aplicações em aço inoxidável, baterias, ligas especiais, químicos, entre outras. Além do ferro e do níquel, a empresa também produz cobre, manganês, bauxita, alumina, alumínio, carvão, cobalto, platina, paládio.

O capital da empresa é brasileiro, composto por um fundo de participações com $32,5 \%$, outros 5,5\% pertencentes ao Governo Federal do Brasil e 62\% pulverizados entre acionistas estrangeiros e brasileiros. As ações da empresa são negociadas na Bolsa de Valores de São Paulo (BOVESPA), Bolsa de Nova York (NYSE), na Euronext Paris e na Bolsa de Madrid - Latibex. A receita bruta da empresa em 2007 foi de 33,115 bilhões de dólares e a geração de caixa (EBITDA) foi de 19,853 bilhões de dólares. Observando o corte da receita por produto, $55 \%$ da receita da empresa vem do minério de ferro e pelotas, o que representa cerca de 314 milhões de toneladas. O níquel representa $16 \%$ das receitas brutas, o que representa cerca de 248 mil toneladas. A participação de cada mercado na receita bruta da empresa é equalizada. 18\% Brasil, 19\% China, 24\% Europa, 21\% Ásia (sem China), 14\% Américas (sem Brasil). Os restantes 4\% se distribuem pelo resto do mundo. No entanto ao identificar as receitas por origem dos produtos, percebe-se uma concentração geográfica no Brasil e América do Norte, com $62 \%$ e $28 \%$, respectivamente. 
A empresa tem operações em vários países do mundo e empregou 146,8 mil pessoas entre empregados próprios (90,4 mil) e prestadores de serviço em atividades permanentes e em projetos (56,4 mil). Do total de empregados em 2007, 81\% se concentraram no Brasil. O restante se distribui no Canadá (7\%), Indonésia (5\%), Nova Caledônia (5\%) e demais países onde a empresa tem operações.

Os investimentos da empresa foram de 7,625 bilhões de dólares em 2007, sem contar as aquisições realizadas. Deste montante, 4,682 bilhões se referem a projetos de crescimento orgânico, 2,202 bilhões se referem a sustentação das operações existentes e 0,741 bilhões se referem a pesquisa e desenvolvimento (P\&D). No período entre 2009 e 2013, a empresa planeja investir 31,5 bilhões de dólares, divididos em projetos, conforme ilustra a figura 6.

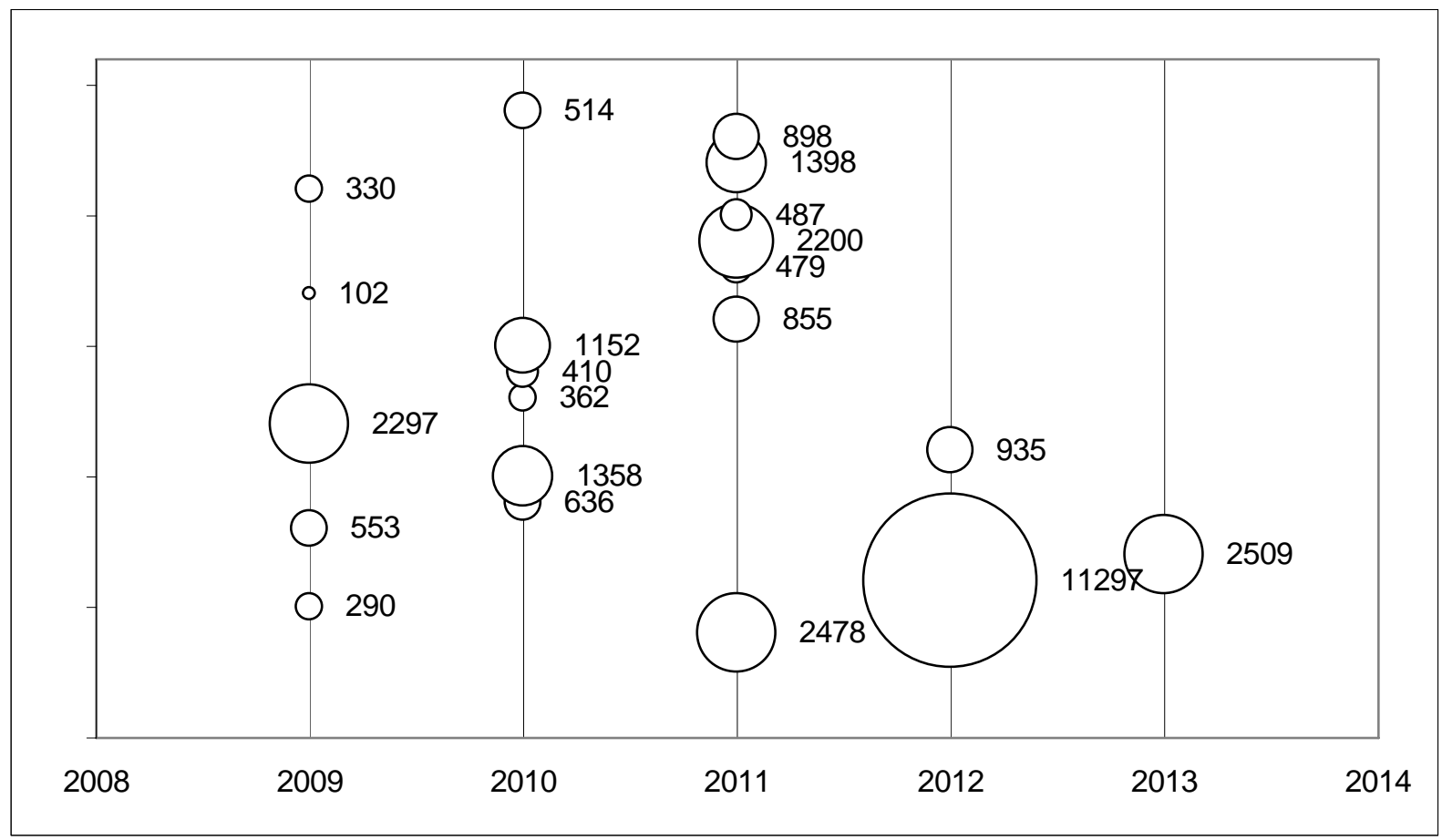

Figura 6: Portfólio de projetos da empresa 4 - Valores em milhões de $R \$$

Fonte: Relatório Anual da Empresa 4 - 2007

A empresa tem 21 projetos de grande porte em seu portfólio no período de 2009 a 2013. Desse total de projetos, 16 deles são considerados green field, ou seja, são projetos iniciados do zero. Os demais projetos são considerados brown field , ou seja, são projetos relacionados a ampliações e melhorias em instalações já existentes. 
Os 21 projetos do portfólio para o período de 2009 a 2013 estão distribuídos nos seguintes negócios da empresa:

- Minério de ferro e pelotas - 4 projetos green field e 2 projetos brown field

- $\quad$ Níquel - 1 projeto green field e 2 projetos brown field

- Carvão - 1 projeto green field e 1 projeto brown field

- Cobre - 2 projetos green field e 1 projeto brown field

- Bauxita \& alumina - 1 projeto green field e 1 projeto brown field

- Fosfatados - 1 projeto green field

- Logística - 1 projeto green field e 1 projeto brown field

- Energia Elétrica - 1 projetos green field

- Siderurgia - 1 projetos green field

No portfólio, 5 projetos representam cerca de $62 \%$ do investimento total, sendo que um desses cinco projetos, sozinho, totaliza aproximadamente 11 bilhões de dólares no período de 2009 a 2013

\subsubsection{Início dos projetos}

Os projetos são iniciados a partir das diretrizes estratégicas, ou seja, os planos da empresa em relação aos seus mercados de atuação. A empresa atua nos mercados de mineração, logística e energia. Dentro dessas áreas de atuação são definidos focos de prioridade. Por exemplo, na mineração é definido o tipo de minério e a área geográfica que serão focos de atenção: minério de ferro, cobre, níquel, diamante, ouro.

Estas grandes diretrizes são desdobradas em campos de atuação que são então organizadas em categorias de oportunidades de negócio: green field, brown field, aquisições, pesquisa geológica ou melhoria daquilo já existente. Por exemplo, a empresa decide consolidar a área de minério de ferro. A partir dessa decisão, são buscadas oportunidades. Uma oportunidade pode ser a melhoria dos ativos existentes. Por exemplo, melhorias numa mina existente para aumentar a produção ou diminuir o custo de operação. Outra 
oportunidade pode ser a busca de novos ativos, como novas áreas de exploração.

A diretriz para a decisão em relação às oportunidades identificadas passa pelo objetivo de negócio que será atendido com a melhoria de um ativo existente ou a construção de um novo ativo. Por exemplo, um novo ativo pode estar relacionado ao atendimento do mercado de automóveis no Brasil. Em seguida é pensado em qual é o nicho alvo deste grande mercado: popular, elegante/confortável, segurança. A partir dessas definições são pensados os projetos relacionados com o atendimento do objetivo proposto. O plano estratégico é plurianual de cinco anos, com revisões anuais.

Existem várias classificações de projeto. Ele é classificado em relação a qual negócio da empresa ele está associado. Outra classificação é se o projeto é green field ou brown field. Por exemplo, um projeto green field seria a abertura de uma nova mina em local onde não havia mina anteriormente; um projeto brown field seria a instalação de uma turbina adicional numa hidrelétrica. Outra classificação é entre projetos de investimento de capital ou de melhoria corrente com foco na eficiência. Por exemplo, a construção de uma estrada numa mina é um projeto de investimento de capital. Outra classificação é pela região geográfica, considerando a atuação internacional da empresa. Outra classificação é definir os projetos por linhas de corte de valor. Acima de 100 milhões de dólares são grandes projetos, de 10 milhões a 100 milhões são projetos de médio porte, abaixo de 10 milhões são projetos de pequeno porte.

Se o projeto é de alta tecnologia e de alto grau de inovação, ele é considerado complexo. Existe uma avaliação de dificuldade técnica da execução de um projeto e uma avaliação do tamanho do projeto. Então, um projeto que tem um investimento muito alto e um escopo muito grande para ser implantado é considerado complexo. A complexidade é atribuída caso a caso em função de diversos fatores, entre eles tecnologia inovadora a ser utilizada no projeto, questões ambientais de difícil equacionamento, isolamento geográfico do site, risco país ou questões de engenharia. 
Não existe um modelo padronizado para todos os projetos. A análise referida acima é feita para cada tipo de projeto sem seguir um processo comum. No entanto, para a dimensão de valor do investimento, o procedimento de análise é similar entre os projetos.

As decisões ocorrem através de comitês. A área de negócio onde o projeto está ligado apresenta sua proposta que é analisada por um steering committee em conjunto com uma consultoria externa. O objetivo da análise é a comparação do projeto com projetos similares do setor no mundo. A empresa tem contrato com a empresa Independent Project Analysis - IPA, uma consultoria de gestão de projetos de engenharia que faz análise de vários projetos de capital de grande porte no mundo. A conclusão da análise é o nível de competitividade da empresa em relação ao projeto analisado, comparativamente ao restante do setor.

Em relação à análise de tempo, em função do complexidade do projeto, são feitas avaliações dos tempos necessários baseados em referências. É evidente que conforme a prioridade do projeto, existirá um esforço para que o projeto ande mais rápido que o normal. No entanto, existem dificuldades a serem vencidas, como os estudos complexos de licenciamento ambiental, cujos tempos, muitas vezes, são independentes da vontade da empresa. Por exemplo, um estudo sobre os ciclos de espécies de flora e fauna existentes num potencial local de exploração de jazida mineral leva no mínimo um ano.

\subsubsection{Estratégias de implantação}

Em relação às implantações dos projetos, a empresa utiliza a metodologia Front-End-Loading - FEL, desenvolvida pela Independent Project Analysis IPA. O projeto é dividido desde a concepção em fases de carregamento (C1, C2, C3,etc), nas quais o projeto vai ganhando definição. Nas fases de carregamento iniciais são identificados os recursos humanos e materiais necessários e a necessidade de integração de disciplinas como engenharia, meio-ambiente, saúde e segurança, entre outras. O objetivo destas ações iniciais é buscar o comprometimento das partes interessadas antes que a construção do projeto seja autorizada. Numa fase seguinte de carregamento, há a definição do que precisa ser feito, é verificado o alinhamento estratégico. 
Em fases posteriores é feita a escolha entre alternativas, o detalhamento do projeto e a preparação do plano de implantação.

Todo esse processo tem um ritual a ser seguido. Existe um projeto conceitual, um projeto básico e um projeto executivo detalhado. Da mesma forma, isso ocorre no planejamento, no orçamento e no cronograma. Paralelamente são feitas atividades que interferem no projeto e no seu planejamento, como levantamento topográfico, geotecnia, levantamento de meio-ambiente. Esta metodologia é utilizada para todos os projetos considerados significativos, com supervisão corporativa para aqueles com investimento superior a 100 milhões de dólares.

Na fase de construção é seguida a metodologia do PMI através das nove áreas de conhecimento referenciadas no PMBOK (2004). Os cronogramas são montados e acompanhados; é feito um plano de suprimentos, desde a requisição técnica do parceiro da engenharia até a entrega do material, da obra e das garantias. Existe um plano de comunicação interna e externa. É feito um plano de riscos.

Quanto maior o grau de complexidade do projeto, maior a exigência do planejamento e do controle. Conseqüentemente, a equipe de gestão do projeto deve ter dedicação integral, a gestão de riscos deve ter maior formalização, a avaliação do plano de implantação é mais rigorosa, a análise das contingências é mais aprofundada, a avaliação dos requisitos financeiros é mais detalhada, a análise de proteções por seguros é solicitada.

Em relação ao grau de inovação dos projetos, existe a preocupação em trazer o conhecimento para dentro do projeto. Também existe a prática de contratar uma consultoria para fazer uma engenharia de valor, onde são checados todos os parâmetros. Nesses casos, são estimados tempos maiores para poder absorver estas práticas durante a fase inicial do projeto.

\subsubsection{Critérios de sucesso}

Em relação aos critérios de sucesso utilizados pela empresa para medir o sucesso de seus projetos, são definidos os seguintes pilares. O projeto deve ter baixo custo, ou seja, menor que o custo médio de projetos similares do 
setor; o projeto deve ter um prazo também menor que o prazo médio de projetos similares do setor; o projeto deve ter uma capacidade de operação mais competitiva que a capacidade operacional média de projetos similares do setor; o projeto não deve ter acidentes de trabalho. Todos esses pilares observados devem dar retorno para o acionista. Na verdade, o que mede o sucesso do projeto é o maior retorno para o acionista.

O peso de cada um desses pilares no sucesso do projeto depende dos direcionadores estabelecidos no início do projeto. Por exemplo, se um projeto precisa estar operando em seis meses, logicamente o tempo é o direcionador desse projeto. Isso significa que haverá um foco maior no atendimento do prazo, não desconsiderando porém os demais pilares do projeto. Em outros projetos, o pilar de custos do projeto pode ser o direcionador.

Por exemplo, supondo que um projeto tenha uma peça de um equipamento quebrada durante a fase de comissionamento. Se for necessário trazer uma peça de reposição a um custo elevado e o direcionador do projeto for o tempo, a decisão será para trazer a peça de reposição para que o projeto não pare, evitando-se possíveis atrasos. Neste caso é tolerado um aumento dos custos para que o prazo seja mantido.

Existe também a preocupação em observar os projetos em termos de desenvolvimento para o futuro. A longevidade de muitas operações no setor mostra a necessidade de estruturação no longo prazo. Por exemplo, existem minas centenárias em operação no mundo. Como a maioria dos negócios do setor é de longo prazo, a qualidade e eficiência da operação é muito importante, exigindo muitas vezes custos mais altos de implantação.

Por exemplo, nos últimos anos (2000-2008), com os altos preços das commodities, o prazo dos projetos foi considerado 0 direcionador predominante. A partir do segundo semestre de 2008, com a baixa nos preços das commodities, o custo de implantação e uma operação mais eficiente passaram a ser fatores fundamentais para obter o retorno esperado para os projetos.

A medição desses critérios de sucesso ocorre na fase de conclusão, ou fechamento do projeto. Neste período o projeto é gradativamente transferido 
para as operações até que seja atingida a capacidade nominal da planta. No caso da empresa este período pode ter de um a três anos. No final deste período são avaliadas as métricas de sucesso do projeto. Por exemplo, a mina está conseguindo operar dentro do custo operacional limite, por exemplo, de US\$4,00 por tonelada de minério. No conceito da empresa, o período de produção também faz parte do ciclo de vida de um projeto de uma nova mina. O ciclo do projeto é encerrado com o fechamento da mina.

No caso específico do negócio de mineração da empresa, os custos de fechamento de uma mina envolvem custos elevados para reconstituir o terreno original. No entanto, a responsabilidade pelo atendimento dos critérios de sucesso do projeto ao longo do seu ciclo de vida é compartilhada. Os profissionais que participam de um projeto de uma nova mina tem características diferentes. Existem os profissionais da área de negócio, os profissionais de engenharia e implantação e os profissionais de operação. Cada fase do projeto tem um responsável. Durante a implantação da mina, o responsável daquela etapa tem interação com os originadores do projeto, que são os profissionais da área de negócio, e também com os operadores da mina, que são os profissionais da área de operação.

A dedicação das equipes de projeto é integral durante a fase de implantação de um projeto. Os projetos complexos são considerados projetos acima de 100 milhões de dólares.

O controle dos projetos é compartilhado com as diversas funções envolvidas: engenharia, planejamento e controle, suprimentos, meio-ambiente, segurança. Os intervalos de acompanhamento variam conforme a fase do projeto, podendo ser semanal, quinzenal ou mensal. A consolidação das informações é mensal, feita através do escritório de engenharia (PMO). Este escritório de projeto inicia seus trabalhos no ciclo de vida do projeto apenas após o projeto já ter sido definido. Esta definição é originada na área de negócio, conforme já foi descrito anteriormente, é validado pelo planejamento estratégico da empresa, e somente após esta validação é que o escritório central de engenharia da empresa inicia sua participação. 
A tabela 12 apresenta como a Empresa 4 trata o início dos projetos, seus critérios de sucesso e as estratégias de gestão de projetos.

\begin{tabular}{|c|c|}
\hline Item & Empresa 4 \\
\hline $\begin{array}{l}\text { Identificação do } \\
\text { tipo de projeto }\end{array}$ & $\begin{array}{l}\text { A empresa } 4 \text { diferencia seus projetos em várias dimensões (área, volume de investimento, } \\
\text { green field, brown field, etc). Estes elementos ajudam nas avaliações de complexidade e } \\
\text { incertezas envolvidas no projeto. Não há um modelo padrão de comunicação desta análise. }\end{array}$ \\
\hline $\begin{array}{l}\text { Critérios de } \\
\text { sucesso e } \\
\text { fracasso }\end{array}$ & $\begin{array}{l}\text { Os critérios utilizados pela empresa são: custo e prazo de implantação menores que a } \\
\text { média do setor em projetos similares; capacidade de operação mais competitiva que a } \\
\text { média do setor; não ocorrência de acidentes de trabalho durante a implantação.; retorno } \\
\text { para o acionista. }\end{array}$ \\
\hline Organização & $\begin{array}{l}\text { Os projetos tem equipes próprias dedicadas ao projeto. Existe suporte do área de } \\
\text { engenharia corporativa para gestão do projeto ao longo do ciclo de vida. A empresa } \\
\text { utilizada a metodologia FEL e tem metodologia própria baseada no PMBOK (2004). }\end{array}$ \\
\hline $\begin{array}{l}\text { Gestão de } \\
\text { requisitos }\end{array}$ & $\begin{array}{l}\text { A empresa } 4 \text { utiliza a metodologia FEL para gerir os requisitos do projeto. No início do } \\
\text { projeto ocorrem reuniões de alinhamento entre as partes interessadas. }\end{array}$ \\
\hline $\begin{array}{l}\text { Criação e } \\
\text { Construção do } \\
\text { produto }\end{array}$ & $\begin{array}{l}\text { O desenvolvimento do projeto do produto ocorre internamente. É prática comum a } \\
\text { contratação de consultorias de engenharia para validar o projeto proposto. As contingências } \\
\text { necessárias para absorver eventuais ocorrências de falhas técnicas no desenvolvimento } \\
\text { são consideradas pela empresa. }\end{array}$ \\
\hline $\begin{array}{l}\text { Re- } \\
\text { planejamento do } \\
\text { projeto }\end{array}$ & $\begin{array}{l}\text { Os projetos são monitorados em intervalos regulares de no máximo } 30 \text { dias. Existe um } \\
\text { controle de mudanças formal nos projetos. }\end{array}$ \\
\hline
\end{tabular}

Tabela 12: Abordagem de gestão de projetos - Empresa 4 


\subsection{Estudo de caso 5}

A empresa 5 pertence ao setor de bens de consumo. Criada na década de 1990, através da fusão de outras empresas, atualmente a empresa é subsidiária de um grupo multinacional. A empresa é líder de mercado no Brasil e América Latina e tem operações em 14 países na região da América Latina e América do Norte.

As operações da empresa envolvem a produção e comercialização de cervejas, refrigerantes, outras bebidas não alcoólicas, malte e subprodutos. Em 2007, a empresa teve uma receita líquida de 19,6 bilhões de reais, com volume de vendas que atingiu 142,9 milhões de hectolitros. Na composição da receita líquida, o Brasil representa cerca de $52 \%$ do total. O restante fica com América do Norte, com 19\% e os demais divididos nos demais mercados da América Latina e América Central.

No final de 2007, a força de trabalho da empresa tinha 37.299 pessoas, divididos nas diversas operações da empresa nos mercados em que atua. Cerca de $58 \%$ desta força de trabalho se concentra nas operações no Brasil.

O controle acionário da empresa é concentrado em dois grupos de acionistas que detém cerca de $70 \%$ do capital da empresa. O restante do capital é pulverizado em ações comercializadas na Bolsa de Valores de São Paulo BOVESPA e na Bolsa de Nova York - NYSE.

Os investimentos em linhas de produção e ativos, não considerando investimentos em fusões e aquisições, totalizou cerca de 1,6 bilhões de reais em 2007.

Os diferenciais competitivos da empresa estão baseados nos seguintes pilares: pessoal e cultura; crescimento de receitas; eficiência e execução de distribuição; permanente redução de custos e despesas; disciplina financeira. Pessoal e cultura: envolve a rigor no processo seletivo e o incentivo ao desenvolvimento de habilidades gerenciais baseadas no respeito à ética, avaliação por resultado, atuação dos executivos como donos e liderança por exemplo. 
Crescimento da receita: busca de crescimento sustentável da receita da empresa através da atuação em quatro frentes: gestão do portfólio de produto com mix de produtos de maior rentabilidade; aumento da participação nos gastos do consumidor com os produtos da empresa; manutenção e fortalecimento da liderança de mercado; aumento do consumo per capita nos mercados em que atua.

Eficiência e execução da distribuição: a capilaridade do sistema de distribuição para milhares de pontos de venda torna este item o elemento mais complexo do negócio da empresa. Por esta razão a empresa internaliza a distribuição nos grandes centros, mas utiliza terceiros nas demais localidades.

Disciplina financeira: a empresa tem a política de não retenção de caixa desnecessário. Após alocar os recursos para as necessidades operacionais e planos de investimento, as eventuais sobras de caixa são passadas aos acionistas através de pagamento de dividendos e recompra de ações.

A unidade específica de análise deste trabalho é o Centro de Engenharia da empresa, que é responsável pelos projetos na área industrial nas operações dos mercados do Brasil e da América Latina. Este núcleo atua principalmente no planejamento e no controle dos projetos. A maior parte das execuções é feita por terceiros contratados. A figura 7 ilustra os processos no ciclo de projetos de engenharia da empresa. 


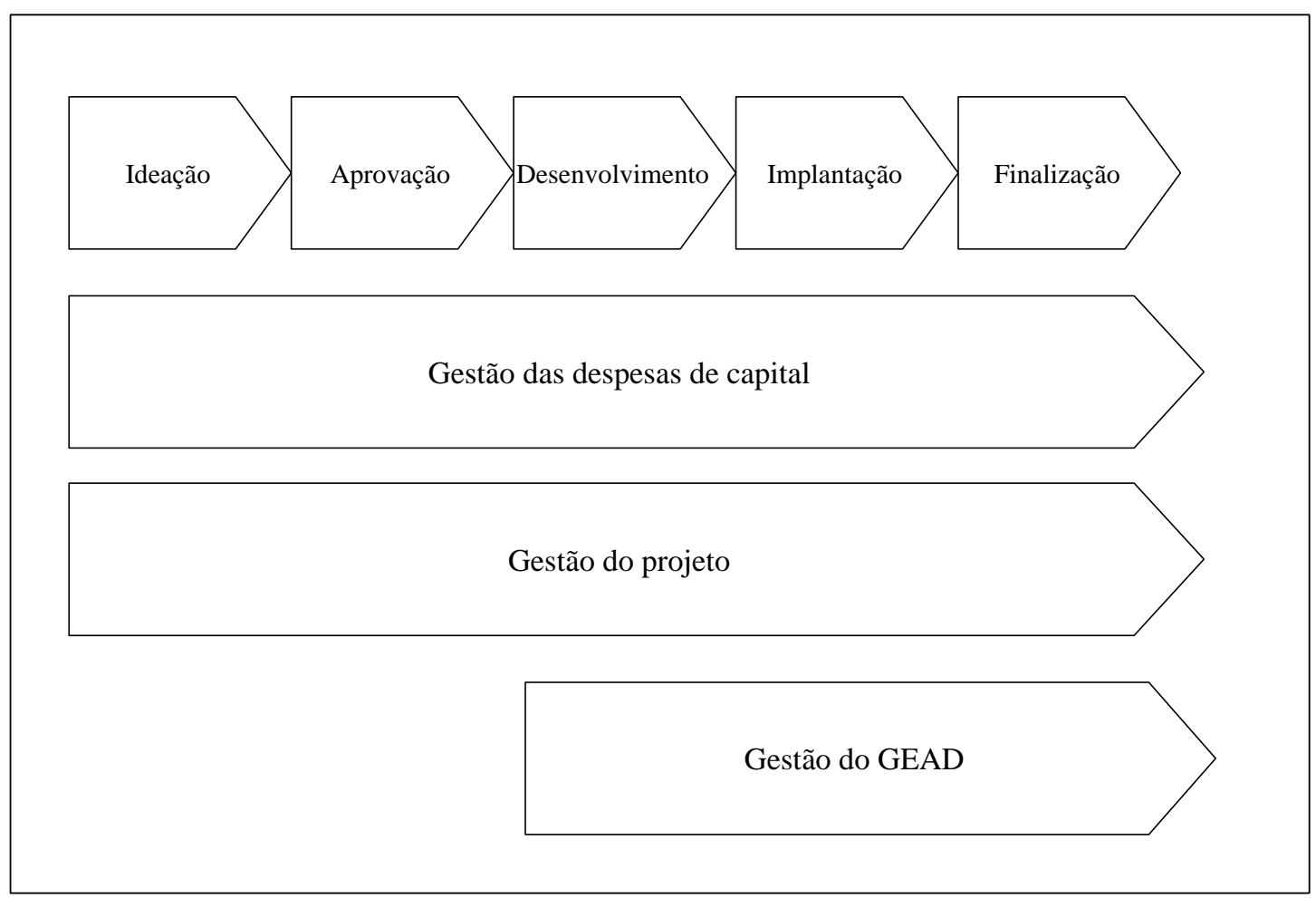

Figura 7: Processos em projetos de engenharia da empresa 5

Fonte: Centro de Engenharia Empresa 5

\subsubsection{Início dos projetos}

A origem dos projetos vem da identificação de oportunidades trazidas pelas diversas unidades operacionais da empresa e pela área de marketing. Todas as iniciativas sugeridas devem estar alinhadas com o planejamento estratégico da empresa.

A partir daí, são levantadas as necessidades, são feitos os alinhamentos, é feita a definição do escopo e do orçamento e realizada a análise de viabilidade e consolidação. Estas informações iniciais são agrupadas e formalizadas num documento inicial do projeto.

Este documento inicial serve de ponto de partida para a análise financeira das despesas de capital (CAPEX), onde são avaliadas as necessidades de investimento e os retornos estimados. As análises financeiras envolvem a montagem de planos de horizontes de um ano e de três anos. Além disso é 
levantado um histórico de investimentos e são feitas análises de tendências de realização. A seguir são alocados os custos aos recursos, são estudadas as verbas disponíveis e a necessidade de transporte de valores anteriores ou de remanejamento de verbas. Finalmente é verificada a necessidade de liberação dos sistemas corporativos (Business Intelligence - BI e Sistema de Gestão Integrada - SAP) para que as despesas do projeto passem a ser contabilizadas na empresa.

Ao final desta fase o projeto é aprovado ou não, seguindo para as etapas seguintes. Percebeu-se uma dificuldade no tratamento da fase de conceituação dos projetos. Não há nenhuma formalidade quanto a processos e estrutura nesta fase do projeto.

Existem cerca de 1.000 projetos por ano no portfólio da empresa na área industrial. Os projetos são divididos em duas grandes categorias: projetos de investimento e projetos de sustentação. Projetos de investimentos envolvem despesas de capital para construção de ativos, como por exemplo a construção de uma nova planta industrial ou a introdução de uma nova linha de produtos numa planta existente. Projetos de sustentação envolvem melhorias de processo com foco na maior produtividade e menor custo, como por exemplo a troca de equipamentos ou o redimensionamento de um processo existente. Dentro dessas categorias não são feitas subdivisões de classificação.

\subsubsection{Estratégias de implantação}

Depois das etapas de ideação e aprovação do ciclo de vida dos projetos na área industrial da empresa, as fases seguintes, chamadas de desenvolvimento, implantação e finalização seguem um método próprio da empresa. Este método está fundamentado na metodologia de gestão de projetos baseada no PMBOK (2004) do Project Management Institute - PMI.

Na etapa de desenvolvimento é feito o planejamento, que inclui a definição do escopo, a montagem do cronograma e a montagem do orçamento executivo. Ainda nesta etapa é verificada a necessidade de licenciamentos e 
é preparada a documentação técnica para contratação dos serviços de construção.

A etapa de implantação inclui as atividades de gestão de projetos referentes ao agendamento e preparação das reuniões de acompanhamento. Nesta etapa também é feita a definição da equipe de acompanhamento e fiscalização do projeto. A equipe do projeto faz o controle das alterações de escopo, através de um procedimento pré-definido e formal da empresa. São definidas rotinas de segurança, que são acompanhadas pela equipe do projeto. É feito um plano de comunicação para distribuição das informações gerenciais. Existe a verificação da necessidade de treinamento dos recursos envolvidos no projeto. Durante essa etapa, a equipe de projeto faz o posicionamento do projeto periodicamente em intervalos mínimos de 15 dias, onde é feita a posição financeira do projeto, são documentadas atas para formalização das reuniões de acompanhamento, são emitidos relatórios de posição mensais do projeto e são seguidos procedimentos para arquivamento da documentação do projeto.

A fase de finalização inclui as atividades relacionadas às liberações finais do projeto. Faz parte desta etapa os encerramentos contratuais com fornecedores e contratados, a preparação da documentação técnica e legal e o encerramento do projeto nos sistemas corporativos.

No entanto, como não existe um processo formal de definir e comunicar as diferenças entre os projetos, não existem estratégias diferenciadas para cada projeto. Os projetos não seguem algum modelo pré-determinado para avaliar as complexidades e as incertezas envolvidas e os conseqüentes riscos. Ou seja, as incertezas referentes ao grau de inovação do projeto e as dificuldades técnicas envolvidas para realizá-lo não tem um processo formal de análise e comunicação entre as partes interessadas. O mesmo ocorre em relação à complexidade referente ao tamanho do escopo do projeto e ao tempo disponível para realizá-lo.

Esta falta de um processo formal de análise da complexidade e incerteza dos projetos acaba prejudicando a prática dos desafios que faz parte da cultura da empresa. Como incentivo e motivação para premiação, é comum o 
patrocinador de determinado projeto colocar um desafio para a equipe de implantação. Estes desafios podem ser uma redução no prazo, uma redução no custo ou uma meta de negócio mais agressiva. No entanto, se a verificação da validade do desafio proposto é feita sem um suporte formal de análise e comunicação que seja entendido pelas partes envolvidas, o que acaba acontecendo é que os desafios são aceitos, mas não são possíveis de serem cumpridos, dadas as condições do projeto.

\subsubsection{Critérios de sucesso}

Os critérios de sucesso observados nos projetos são o atendimento dos prazos e custos dos projetos e o atendimento das metas de negócio. As metas de negócio relacionados ao centro de engenharia industrial da empresa são divididos em duas categorias iniciais: critérios econômicos e critérios de viabilidade.

A categoria dos critérios econômicos inclui os seguintes itens, considerando a linguagem da empresa:

- Capacity driven: aqui se incluem métricas associadas a ampliação de capacidade e/ou aumento de vendas

- Consumer driven: aqui se incluem métricas associadas a enquadramento com a solicitação de consumidores

- Cost driven: aqui se incluem métricas associadas a redução de custos operacionais

A categoria dos critérios de viabilidade inclui os seguintes itens, considerando a linguagem da empresa:

- Quality driven: aqui se incluem métricas associadas a garantia de melhor qualidade para os produtos.

- Upholding production potential driven: aqui se incluem métricas associadas a garantia de disponibilidade de equipamentos e instalações através da substituição ou prolongamento da vida útil dos mesmos. 
- Environmental, health, safety, legal and social driven: aqui se incluem métricas associadas a proteção de ativos, pessoas e meio ambiente, conforme legislação ou normas.

As métricas contidas na categoria de critérios econômicos são uma definição corporativa, podendo ser aumentadas ou reduzidas em função da demanda de mercado ou identificação de novas tecnologias de redução de custos. As métricas contidas na categoria de critérios de viabilidade são definidas com base no histórico de investimentos dos últimos anos, podendo ser influenciadas por aumento significativo de volume.

Não foi observada nenhuma métrica referente ao desenvolvimento de pessoal nos projetos ou ainda métricas relacionadas à preparação para o futuro.

A tabela 13 apresenta como a Empresa 5 trata o início dos projetos, seus critérios de sucesso e as estratégias de gestão de projetos.

\begin{tabular}{|c|c|}
\hline Item & Empresa 5 \\
\hline $\begin{array}{l}\text { Identificação do } \\
\text { tipo de projeto }\end{array}$ & $\begin{array}{l}\text { Os projetos são divididos inicialmente em projetos de investimento e projetos de sustentação. Não } \\
\text { existe uma avaliação formal de complexidade e incerteza envolvidas num projeto. }\end{array}$ \\
\hline $\begin{array}{l}\text { Critérios de } \\
\text { sucesso e } \\
\text { fracasso }\end{array}$ & $\begin{array}{l}\text { São avaliados o atendimento do prazo e do custo dos projetos e o atendimento das metas de } \\
\text { negócio. As metas de negócio são subdivididas em critérios econômicos e critérios de viabilidade } \\
\text { (veja descrição do item 5.5.3) }\end{array}$ \\
\hline Organização & $\begin{array}{l}\text { A empresa tem metodologia própria baseada no PMBOK (2004). Os líderes de projeto são } \\
\text { compartilhados e ficam subordinados aos coordenadores de áreas. }\end{array}$ \\
\hline $\begin{array}{l}\text { Gestão de } \\
\text { requisitos }\end{array}$ & $\begin{array}{l}\text { A metodologia de gestão de projetos da empresa não trata em detalhes a formalização dos } \\
\text { processos de gestão de requisitos no início dos projetos. }\end{array}$ \\
\hline $\begin{array}{l}\text { Criação e } \\
\text { Construção do } \\
\text { produto }\end{array}$ & $\begin{array}{l}\text { Equipe experiente de desenvolvimento minimiza os riscos técnicos do projeto. No entanto, não } \\
\text { existe o tratamento de contingências necessárias para cobrir eventuais problemas técnicos } \\
\text { decorrentes do uso de alguma tecnologia não testada anteriormente. }\end{array}$ \\
\hline Replanejamento & Existe controle formal de mudanças no projeto durante a fase de implantação. \\
\hline
\end{tabular}

Tabela 13: Abordagem de gestão de projetos - Empresa 5 


\subsection{Estudo de caso 6}

A empresa 6 pertence ao setor agrícola, com atuação em pesquisa e desenvolvimento de tecnologias inovadoras para o setor. As pesquisas abrangem toda a cadeia produtiva do setor agrícola.

A história da organização foi iniciada, como um centro de tecnologia de um setor agrícola específico. Passados alguns anos, o Centro se tornou uma empresa independente, sem fins lucrativos, mantida por um conjunto de empresas do setor que se beneficiam com as novas tecnologia pesquisadas e desenvolvidas pela empresa em estudo.

A contribuição da empresa para o setor tem sido o desenvolvimento de lavouras e processos industriais de alta produtividade. Na lavoura, os produtores tem a seu dispor tecnologias que permitem utilizar espécies adaptadas às condições do solo e do clima. $\mathrm{Na}$ indústria, altos níveis de eficiência podem ser atingidos pela disponibilização de tecnologias que permitem o reaproveitamento de subprodutos da lavoura e da área industrial, formando um ciclo fechado, reduzindo desperdícios.

Além disso, o avanço da tecnologia permite o aproveitamento de subprodutos da lavoura. Um dos subprodutos volta à lavoura como nutriente orgânico. Outro subproduto é utilizado para geração de energia, garantindo a auto-suficiência nas fazendas e indústrias. Além disso, a água utilizada na indústria pode ser reciclada para reduzir consumo. Um insumo do processo industrial pode ser recuperado e utilizado para produção de ração animal. .

Os programas de pesquisas e desenvolvimento da empresa são agrupados de acordo com os seguintes temas:

- Variedades

- Fitossanidade

- Biotecnologia

- Agronomia

- Mecânica agrícola e industrial 
- Produção industrial

- Produção de energia

A empresa oferece cerca de 100 produtos e serviços relacionados aos programas de pesquisa e desenvolvimento citados. Entre os produtos oferecidos pode-se destacar como exemplos:

- Rastreamento via satélite: a empresa rastreia e identifica variedades de plantas possibilitando desta forma, o aprimoramento das previsões de safra e do acompanhamento das plantações.

- Controle biológico de pragas: a empresa desenvolveu sistemas eficientes e seguros de diagnóstico e soluções de doenças por meio de análise do DNA.

- Procedimentos de produção e armazenagem: a empresa aplica conceitos de segurança alimentar na produção industrial; sistema de limpeza, colhida mecanicamente, possibilita reduzir impurezas e aumenta a eficiência da produção industrial.

- Produção industrial: consolidação das tecnologias utilizadas, com novos métodos de controle operacional e automático, e a otimização do processo de fabricação e do consumo de energia.

\subsubsection{Início dos projetos}

O início dos projetos na empresa 6 vem de um banco de idéias que é alimentado internamente e externamente. Internamente, dois coordenadores de P\&D da empresa tem atribuição adicional de fazer uma varredura sobre tópicos que estão sendo pesquisados sobre o setor específico em todo o mundo. Além disso, ainda internamente, todos os colaborares da empresa têm oportunidade de contribuir com idéias para desenvolvimento de pesquisas. Externamente, os diversos associados da empresa, tem oportunidade de expressarem suas necessidades, que podem levar a desenvolvimento de novas pesquisas.

As novas idéias passam por um primeiro filtro, que consiste de uma avaliação feita por um comitê interno composto pelos coordenadores de pesquisa 
sobre a viabilidade da idéia proposta. Os critérios utilizados por esse comitê interno composto pelos coordenadores de P\&D são derivados das diretrizes estratégicas da empresa referentes aos temas de pesquisa relevantes.

Estas diretrizes estratégicas de pesquisa fazem parte do planejamento estratégico, no qual a empresa definiu as seguintes condições críticas de sucesso:

- Pesquisa

- Configuração organizacional

- Modelo de negócios

- Modelo de gestão de pessoas

- Alianças e parcerias

- Disseminação e transferência de tecnologia

$\mathrm{Na}$ condição crítica de pesquisa, o planejamento estratégico definiu as seguintes iniciativas: estabelecer linhas de pesquisa, desenvolver radar tecnológico, estabelecer competências e capacidades, desenhar modelo de filtro e priorização, definir modelo de gestão do conhecimento, definir metodologia de pesquisa.

Após passar pela análise inicial dos coordenadores, os proponentes são instruídos a preparar uma apresentação da idéia proposta para o Conselho da empresa, composto pela equipe executiva da empresa e por representantes externos. O conselho dá a palavra final sobre a seqüência ou não das iniciativas vindas dessas idéias.

As iniciativas não têm uma classificação formal de complexidade e incerteza. Existe, no entanto, uma classificação de cada iniciativa em relação às áreas pertinentes. Uma iniciativa pode ser de pesquisa e desenvolvimento ou de transferência de tecnologia. Dentro dessas áreas existem subclassificações, de acordo com o tema específico: agrícola, fitossanitário, industrial.

As iniciativas também não são classificadas formalmente em programas, projetos e rotinas. Há confusão em relação a cada um desses tópicos, como por exemplo as atividades de ensaios relativos à área de fito sanidade, que 
se repetem ao longo do tempo de acordo com o calendário do cultivo do setor específico.

Independente da classificação, cada iniciativa recebe um código para cadastramento num sistema de gestão financeira, que serve para acompanhamento das horas despendidas e dos custos do projeto.

\subsubsection{Estratégias de implantação}

Após a aprovação da iniciativa e cadastramento de seu respectivo código no sistema de gestão financeira, cada líder de projeto monta um plano de execução, supervisionado pelo coordenador da área na qual o projeto está pendurado. Este plano não tem uma padronização e não segue nenhuma metodologia referenciada de gestão de projetos.

Os projetos de pesquisa e desenvolvimento contidos no portfólio da empresa tem duração usual entre dois e três anos, alinhados com os períodos anuais dos cultivos agrícolas.. Isto ocorre, porque as soluções desenvolvidas nos laboratórios precisam ser testadas em campo e a observação de resultado ocorre do plantio até a colheita.Apesar de não seguir uma metodologia formal, foram observadas práticas de gestão compatíveis com as abordagens contingenciais. Por exemplo, num projeto relacionado a uma solução inovadora de produção industrial a partir de um subproduto do cultivo, foi utilizado uma planta piloto em escala menor para testar o processo proposto. A observação de problemas durante o piloto possibilitaria a identificação de falhas e problemas, que poderiam ser tratados antes de escalonar o processo em nível industrial.

Outro exemplo são as estratégias de parcerias firmadas pela empresa em projetos que envolvam tecnologias ou competências que a empresa não domine. Por exemplo, num projeto de desenvolvimento de um equipamento de transporte rodoviário com caixas em alumínio para reduzir a tara (peso sem carga) do equipamento com a mesma resistência, foram utilizadas parcerias para desenvolvimento do processo industrial de fabricação da carroceria. Em outros projetos, foi observado a formação de parcerias com universidades para desenvolvimento de novas tecnologias. 
Outra estratégia observada é o estabelecimento de contingenciamentos nos projetos. Vários projetos da empresa envolvem testes de campo em áreas de cultivo e produção. Para que esses testes sejam realizados, deve ser disponibilizada uma área de sua lavoura. No entanto, foi observado que é comum descobrir, no momento da realização dos ensaios, que as áreas não estão disponíveis. É prática comum na empresa pedir a reserva de $50 \%$ a 100\% a mais de quantidade de áreas e ainda pedir reservas de mais de uma área.

O nível de formalização e padronização dos planos de implantação de projetos é baixo. Observou-se que os projetos tem documentações formais, mas com conteúdo predominante técnico, sendo observados poucos elementos referentes à gestão de projetos, como análises de risco, planos de comunicação, entre outros. Os documentos de gestão de projetos observados na empresa são diferentes entre si. Por exemplo, a montagem de cronogramas não segue uma padronização.

No entanto, por não haver uma padronização de processos de gestão de projetos, decisões como essas são tomadas de acordo com a experiência dos líderes e coordenadores de projeto envolvidos. Isso acaba aumentando as chances de insucesso dos projetos.

A estrutura organizacional da empresa é feita em coordenadorias que agrupam projetos relacionados a cada área específica. Os líderes de projeto, subordinados às respectivas coordenadorias, tem dedicação integral a alguns projetos. No entanto, foi observado que o papel de gestor do projeto acaba sendo compartilhado entre o líder e o coordenador.

O monitoramento dos projetos é feito pelos líderes e coordenadores sem padronização para toda a organização. Cada coordenadoria em conjunto com a diretoria respectiva adota um tipo de relatório de acompanhamento dos projetos, com periodicidade e conteúdos próprios. A gestão de mudanças que ocorrem nos projetos são tratadas diretamente pelos diretores e coordenadores caso-a-caso, sem utilização de uma padronização comum para toda a empresa. 


\subsubsection{Critérios de sucesso}

Os projetos utilizam critérios multidimensionais de sucesso. Cada projeto tem suas próprias metas de tempo e custo que são explicitadas nos planos de projeto. Outros critérios são utilizados, mas não aparecem de maneira clara nos planos dos projetos.

Por exemplo, os critérios referentes aos benefícios de um projeto de P\&D para o negócio do setor aparecem indiretamente nos planos de projetos. No entanto, observou-se a predominância de métricas qualitativas nos projetos, como: aumentar a produtividade da lavoura, diminuir o consumo de insumos na produção industrial.

Observa-se também que não existe uma priorização formal das metas, mas fica claro que atender o prazo do projeto não é um critério direcionador dos projetos da empresa. Em decisões do projeto, como por exemplo num projeto de desenvolvimento de um novo processo industrial houveram falhas em um equipamento fabricado que levaram à necessidade de troca de uma peça do equipamento. A troca da peça envolvia duas alternativas. A primeira seria importar a peça pronta a um custo $X$ com atraso de apenas 15 dias no projeto. A outra alternativa seria fabricar uma nova peça no Brasil a um custo de $X / 2$, com atraso de 60 dias no projeto. A decisão neste caso foi a segunda alternativa, pois o prazo não era o direcionador do projeto. O atraso gerado poderia ser justificado. O aumento de custo era mais difícil de ser justificado.

A definição de métricas de sucesso do projeto para o setor torna-se mais complexa, pois o resultado dos projetos são a disponibilização e recomendação da aplicação de novas tecnologias. No entanto, a aplicação dessas tecnologias é uma decisão de cada empresa do setor, o que acaba tornando difícil a verificação dos resultados esperados pela aplicação da nova tecnologia.

Por exemplo, um projeto de P\&D da empresa disponibilizou uma tecnologia que diz aumentar o resultado da produção em $25 \%$. No entanto, a checagem deste resultado depende da aplicação da tecnologia no setor e posterior medição dos resultados num determinado intervalo de produção. 
Outras métricas, relacionadas a impacto na equipe do projeto ou impacto para o futuro acabam aparecendo nos projetos de forma indireta e são difíceis de serem medidas. Por exemplo, num projeto de P\&D que envolveu o desenvolvimento de um método para controle de uma praga, segundo um dos coordenadores da pesquisa, era esperado que pelos menos um dos pesquisadores envolvidos adquirisse conhecimento suficiente para publicar um artigo em uma revista científica de renome internacional sobre o tema de controle das pragas estudadas na lavoura.

Em relação a métricas referentes a desenvolvimento de futuro, implicitamente, os projetos de P\&D embutem expectativas de que os resultados obtidos possam criar opções de novos negócios e mercados para a empresa. Por exemplo, a empresa tinha em seu portfólio um projeto de pesquisa, cujo objetivo era selecionar genes envolvidos em acúmulo de carboidratos, através da prospecção e avaliação, em dois anos, de 10 genes de plantas transformadas em regime de contenção. A seleção destes genes possibilitariam no futuro a obtenção de uma variedade genética com maior teor de carboidrato.

A falta de uma formalização das métricas de sucesso dos projetos é fonte de conflitos entre os pesquisadores, a direção da empresa e os acionistas. Esta constatação pode ser observada em comentários de um dirigente da empresa durante uma reunião de aprovação de um projeto de pesquisa específico. O apresentador dizia que o sucesso do projeto era a entrega do relatório final da pesquisa, enquanto o dirigente dizia que a simples entrega de um relatório não representava o sucesso do projeto. Sucesso para o dirigente era atender a expectativa de melhoria para o negócio do setor.

A tabela 14 apresenta como a Empresa 6 trata o início dos projetos, seus critérios de sucesso e as estratégias de gestão de projetos. 


\begin{tabular}{|c|c|}
\hline Item & Empresa 6 \\
\hline $\begin{array}{l}\text { Identificação do } \\
\text { tipo de projeto }\end{array}$ & $\begin{array}{l}\text { Os projetos não são avaliados formalmente quanto a complexidade e incertezas envolvidas. } \\
\text { Uma classificação existente é posicionar o projeto em programa, projeto ou processo. No } \\
\text { entanto, tal classificação é confusa pois não há critérios claros de diferenciação. }\end{array}$ \\
\hline $\begin{array}{l}\text { Critérios de } \\
\text { sucesso e } \\
\text { fracasso }\end{array}$ & $\begin{array}{l}\text { São utilizados critérios multi-dimensionais, mas sem explicitação clara nos planos ou } \\
\text { documentos de projeto. O prazo e o custo dos projetos ficam explicitados, mas os critérios } \\
\text { utilizados para justificar o projeto para as empresas associadas ficam dispersos e } \\
\text { desestruturados dentro dos planos do projeto. Além disso, não há métricas para possibilitar } \\
\text { avaliações objetivas. }\end{array}$ \\
\hline Organização & Não existe uma metodologia de gestão de projetos referenciada em modelos conhecidos. \\
\hline $\begin{array}{l}\text { Gestão de } \\
\text { requisitos }\end{array}$ & $\begin{array}{l}\text { Foram observadas práticas de gestão de requisitos, mas sem processo formal. A gestão } \\
\text { dos requisitos é apoiada na experiência e estilo gerencial dos coordenadores e líderes de } \\
\text { projeto. }\end{array}$ \\
\hline $\begin{array}{l}\text { Criação e } \\
\text { Construção do } \\
\text { produto }\end{array}$ & $\begin{array}{l}\text { Equipe experimentada e qualificada reduz chances de erros técnicos nos projetos. Quando } \\
\text { a empresa não tem competência, o reconhecimento é claro e adotam-se parcerias e } \\
\text { contratações de consultorias e empresas externas que têm domínio sobre a técnica ou } \\
\text { tecnologia requerida. }\end{array}$ \\
\hline $\begin{array}{l}\text { Re- } \\
\text { planejamento do } \\
\text { projeto }\end{array}$ & $\begin{array}{l}\text { Os projetos são re-planejados, mas não há um monitoramento organizado e estruturado. } \\
\text { Cada diretor, em conjunto com seus coordenadores, é que define como será } 0 \\
\text { acompanhamento. }\end{array}$ \\
\hline
\end{tabular}

Tabela 14: Abordagem de gestão de projetos - Empresa 6 


\section{Capítulo 6}

\section{Análise dos resultados}

Este capítulo apresenta os resultados deste trabalho, obtidos através do desenvolvimento das duas questões de pesquisa definidas no capítulo 2 . Utilizou-se para isso estudos de casos, conforme metodologia proposta no capítulo 4.

Os estudos de caso com cada uma das empresas foram apresentados no capítulo 5 para que esse capítulo tratasse apenas das análises conjuntas e dos resultados gerais obtidos através dos casos estudados.

\subsection{Dinâmica de definição e gestão de projetos complexos e incertos}

O resultado apresentado neste item refere-se à primeira questão de pesquisa deste trabalho: "Como são definidos e geridos os projetos complexos e incertos em empresas que atuam no Brasil?"

Cada caso selecionado foi descrito individualmente no capítulo anterior. Neste capítulo, a análise das informações é realizada e apresentada em conjunto, dividida conforme as categorias estudadas nos estudos de caso.

\subsubsection{Identificação do tipo de projeto}

Em relação a esse tópico foi verificada a maneira que as empresas diferenciam seus projetos, se existe uma avaliação inicial de complexidade e incerteza dos projetos e como a diferenciação dos projetos é comunicada entre os executivos e as equipes gerenciais de projeto.

Percebeu-se que a diferenciação dos tipos de projeto é tratada de forma heterogênea e pouco estruturada em cada uma das unidades de análise das empresas estudadas. 
A empresa 1 tem um processo formalizado de planejamento estratégico, que identifica e classifica iniciativas que podem se tornar um projeto. Os critérios observados para diferenciar as iniciativas são o crescimento e rentabilidade que a iniciativa pode trazer ao negócio da empresa e a aderência da iniciativa aos processos existentes. Usando estes dois critérios, a empresa posiciona seus projetos uma das três seguintes categorias: projeto estratégico, projetos seis-sigma e rotina.

$\mathrm{Na}$ empresa 2, não existe um processo formal de identificação e classificação. Apesar disso, um comitê toma a decisão de classificar as iniciativas propostas num determinado ano em projetos estratégicos ou nãoestratégicos. Os critérios adotados nesta classificação são a disponibilidade de recursos, a prioridade da iniciativa e a existência de condições para trabalhar na iniciativa no momento, entre outros fatores.

Na empresa 3, também não existe uma identificação e classificação de tipo de projeto. No entanto, o executivo ou gestor da iniciativa proposta, usualmente classifica os projetos em simples e complexos, usando critérios não explicitados e não padronizados para definir as categorias de projetos.

A empresa 4 tem um processo formal de identificação do tipo de cada projeto. Além dessas categorias, os projetos também são diferenciados pela área de negócio, pela localização geográfica, pelo ponto de partida (green field ou brown field) e pelo valor de investimento.

A empresa 5 diferencia formalmente seus projetos na área industrial em projetos de investimento ou projetos de sustentação. Os projetos de investimento são despesas de capital para construção de novos ativos industriais e os projetos de sustentação são despesas com foco no aumento de produtividade e na redução de custos dos ativos industriais existentes.

A empresa 6 diferencia seus projetos através de duas classificações. Os projetos são classificados pela área envolvida (agrícola, fitossanitário, industrial) e pela natureza das atividades (P\&D ou Transferência de Tecnologia).

As dimensões de diferenciação sugeridas por Shenhar e Dvir (2007) são consideradas de maneira fragmentada e parcial nas avaliações iniciais dos 
projetos nas empresas estudadas, mas não existe uma classificação formal de complexidade e incerteza de cada projeto. A dimensão de grau de inovação do resultado do projeto para os usuários é considerada explicitamente apenas pela empresa 4 ao fazer as análises iniciais de projeto. A dimensão de incerteza sobre a tecnologia ou as atividades do projeto é avaliada antecipadamente de forma explícita pela empresa 4. A dimensão de complexidade não é avaliada explicitamente por nenhuma das empresas. A dimensão de ritmo necessário não é avaliada explicitamente por nenhuma das unidades de análise estudadas nas empresas.

Entretanto, indiretamente e informalmente estas dimensões são levadas em conta nas análises de projetos, conforme pode ser observado em muitas das estratégias utilizadas para implementar projetos nas empresas. As evidências documentais observadas nas empresas sobre estas análises são fragmentadas, incluídas como parte de documentos de apresentações de projeto. Nas entrevistas nas empresas, ficou bem evidenciado que os gestores e executivos levam em conta as dimensões do modelo de Shenhar e Dvir (2007), entre outras, ao definirem várias estratégias de gestão de projetos e definirem critérios de sucesso.

A comunicação do resultado dessas análises, no entanto, parece ser deficiente. Na empresa 3, o entrevistado deu um exemplo de um projeto que ele avaliava como de alta complexidade, mas que a consultoria e os executivos envolvidos avaliavam não ser tão complexo. A evidência desta disparidade de análise foi o estabelecimento do prazo do projeto em sete meses pelos executivos e pela consultoria. Segundo o entrevistado, desde o início ele dizia que seria impossível atender o prazo de sete meses, mas não conseguiu convencer os demais envolvidos. Ao final o projeto foi terminado em 12 meses, acréscimo de cerca de $71 \%$ sobre o prazo original.

A Tabela 15 ilustra os pontos observados de cada empresa em relação à identificação do tipo de projeto. 


\begin{tabular}{|c|c|c|c|c|c|}
\hline Empresa 1 & Empresa 2 & Empresa 3 & Empresa 4 & Empresa 5 & Empresa 6 \\
\hline
\end{tabular}

Tabela 15: Pontos observados nas empresas - categoria: identificação do tipo de projeto 


\subsubsection{Critérios de sucesso}

Em relação aos critérios de sucesso dos projetos foram observados três itens: definição dos critérios, priorização dos critérios e medição dos critérios. $\mathrm{Na}$ definição dos critérios, percebeu-se que as empresas estudadas utilizam critérios multidimensionais para definir e avaliar o sucesso de seus projetos, mas a maneira de definir estes critérios varia de uma empresa para outra.

Observando as categorias de critérios sugeridas no modelo de Shenhar e Dvir (2007), percebeu-se o uso de critérios de eficiência, de impacto no consumidor e de impacto para o negócio. Foi constatado também que nenhuma das empresas estudadas tem critérios formais referentes a impacto na equipe de projeto e referentes a preparação da organização para o futuro.

Na empresa 1, o sucesso dos projetos estratégicos é focado no cumprimento dos prazos e do orçamento e no atendimento de metas financeiras e/ou operacionais. $\mathrm{Na}$ empresa 2, o sucesso dos projetos está ligado ao atendimento de métricas operacionais e de negócio, com pouca ênfase sobre o atendimento dos prazos. Na empresa 3, os critérios de sucesso dos projetos utilizam métricas operacionais e financeiras para medir o resultado dos projetos. O prazo e o custo também são observados. Na empresa 4, os critérios levam em conta o prazo, o custo de implantação, métricas operacionais e de segurança de trabalho e métricas de impacto no negócio. A empresa 5 utiliza o prazo e o custo dos projetos e métricas operacionais, de segurança e de negócio. Os critérios de negócio são divididos em duas categorias: econômica e viabilidade. A empresa 6 observa critérios de prazo, custo e benefício para o negócio do associado.

No entanto, a falta de formalização de alguns critérios sugeridos por Shenhar e Dvir (2007) não significa que tais critérios não sejam considerados pelos gestores e executivos das empresas. Por exemplo, na empresa 3, foi expressado por um dos entrevistados que um dos critérios que ele utiliza com freqüência em seus projetos é a capacitação técnica e gerencial adquirida pela equipe do projeto para gerenciar projetos similares num futuro próximo, sem depender da contratação de uma consultoria externa. Na empresa 6, em 
um projeto de $P \& D$, que envolvia o estudo genético de uma variedade de planta, a diretoria e a coordenadoria do projeto tinham uma meta implícita do de que o resultado do projeto permitiria à empresa ter a opção de participar em projetos subseqüentes que buscavam ter uma variedade de planta com $20 \%$ a mais de teor de carboidratos.

Na priorização dos critérios, percebeu-se que nenhuma das empresas utiliza um sistema formal de pesos para definir previamente a importância de cada critério no sucesso do projeto. Outra observação foi a falta de conexão entre a classificação dos projetos e a priorização dos critérios de sucesso dos projetos.

A importância dos critérios acaba sendo explicitada somente quando há necessidade de tomada de decisão em algum momento durante a condução do projeto. Na tomada de decisão, algum dos critérios acaba prevalecendo em detrimento dos demais, descobrindo-se neste momento qual critério é mais ou menos crítico para o projeto.

Nas empresa 1, não existe uma priorização inicial da importância dos critérios, mas ficou evidente, no entanto, que existe uma prioridade não explicitada, que acaba sendo manifestada durante tomadas de decisão do projeto. Na empresa 2, foi feita a mesma constatação da empresa 1. Na empresa 3, em projetos considerados complexos, o atendimento do prazo e do custo são observados, mas existe uma tolerância em relação a possíveis desvios. O mais importante nestes projetos é atender as métricas operacionais e de negócio. Na empresa 4 não existe um sistema de pesos, sendo que a importância relativa dos critérios é estabelecido conforme os direcionadores estratégicos definidos no início do projeto e eventualmente revisados ao longo do tempo, em função de alterações no ambiente de negócio. Na empresa 5 não existe um processo para atribuir pesos aos critérios definidos.

No entanto, apesar de não haver um modelo formal de priorização, percebeuse que os gestores e executivos tem a percepção de qual dos critérios é o mais crítico. Por exemplo, em projetos na empresa 4, uma variável incerta é o preço do minério de ferro no mercado. Foi comentado pelo executivo 
entrevistado na empresa que o direcionador de projetos de capital da empresa até a metade de 2008 era o atendimento do prazo. Quanto antes o projeto terminasse melhor era, pois mais cedo se poderia comercializar o produto com maior margem. A situação se inverteu a partir da metade de 2008, com a forte queda do preço do minério de ferro. A partir de então, o direcionador de novos projetos passou a ser o menor custo de operação possível.

Em relação às medições dos critérios de sucesso dos projetos, foi observada a dificuldade das empresas em medir critérios que não sejam atribuídos a tempo e custo do projeto. Isto parece estar ligado à forma como as empresas tratam a responsabilidade pelos resultados dos projetos. Outro ponto de destaque foi a dificuldade de estabelecer métricas quantitativas.

Outro ponto em relação à medição dos critérios foi a dificuldade de encaixar a medição dos critérios dentro do ciclo de vida do projeto. Isto acaba limitando a avaliação de alguns critérios de médio e longo prazo.

A dificuldade em estabelecer métricas quantitativas foi observada nos projetos de P\&D da empresa 6. Especificamente, existem dificuldades na quantificação do impacto do resultado do projeto para o sucesso do negócio do associado. Foram observadas métricas gerais, como melhoria da produtividade, aumento da área plantada, ou redução de custo por hectare de plantio. No entanto, o uso de métricas não específicas leva a diferentes interpretações de resultados. Por exemplo, uma redução de $10 \%$ no custo de manejo por hectare é bom ou ruim?

Em relação à responsabilidade pelo sucesso do projeto, Shenhar e Dvir (2007) comentam que os gerentes e equipes de projetos deveriam ser avaliados de acordo com seus desempenhos em todas as dimensões de sucesso, sejam de curto ou de longo prazo. Ou seja, os gerentes de projeto são responsáveis por atingir o sucesso do projeto em todas as dimensões.

O que foi observado nas empresas estudadas é que a responsabilidade pelo sucesso do projeto é tratada de maneira heterogênea por cada empresa. Apenas na empresa 3, nos projetos exemplificados pelos entrevistados, 0 responsável de implantação do projeto e o gestor das operações que recebe 
o resultado do projeto foi o mesmo. Nas demais empresas, observou-se que há a separação de responsabilidades entre o gestor da implantação do projeto e o gestor das operações. Segundo os entrevistados, a racionalidade para esta abordagem é a dificuldade em separar as responsabilidades entre as equipes de projeto e a área da organização que recebe o resultado do projeto.

Na empresa 1, as métricas utilizadas são limitadas à possibilidade de medição durante o período definido para o ciclo de vida do projeto. Eventuais métricas que sejam verificáveis num prazo mais longo, que excede o prazo do projeto, não são incluídas no projeto. Para tentar acomodar medições de métricas relativas a negócio, que só são possíveis após a entrega do projeto, a empresa estende o ciclo de um projeto em três meses a um ano. Neste período adicional são feitas as medições de verificação do atendimento dos critérios de impacto sobre o negócio, como aumento de vendas, redução de custos, entre outros. No entanto, este período de três meses a um ano pode não ser suficiente para medir impactos de longo prazo do projeto.

Na empresa 2, as medições das métricas são anualizadas. Ao final de cada ano são verificadas as métricas e o comitê de planejamento estratégico da unidade decide pela continuidade ou não do projeto. Isto explica a pouca ênfase no prazo dos projetos, segundo o entrevistado. Mesmo um projeto que tenha prazo previsto de mais de um ano, suas metas são definidas para serem observadas no período de um ano. Nestas avaliações anuais são incluídas métricas operacionais e financeiras.

A anualização dos resultados dos projetos acaba facilitando a incorporação de métricas de médio e longo prazo, mesmo havendo a separação de responsabilidades entre implantação e operação. Por exemplo, quando um projeto termina de ser implantado em outubro, são estabelecidas metas de acompanhamento deste projeto para o ano seguinte e novas medições são feitas.

Na empresa 3, a maneira como fazer as medições das métricas de sucesso do projeto não são claras no início do projeto, mas, conforme já foi dito, nos 
projetos descritos pelos entrevistados, a responsabilidade pelo projeto foi única, desde a implantação até a operação.

$\mathrm{Na}$ empresa 4, a medição dos critérios é feita no período do projeto, abrangendo períodos longos que incluem a operação e o fechamento da jazida de exploração. No entanto, segundo o executivo entrevistado, existe uma separação de papéis entre implantação e operação. O foco do gestor da implantação são metas de eficiência, como atendimento do prazo e do custo. $\mathrm{O}$ foco do gestor das operações é conseguir atender um determinado custo de produção combinado no início do projeto.

Na empresa 5, a medição dos critérios é normalmente limitada ao período do projeto. Verificou-se também que a fase final dos projetos acaba abrangendo a transferência do resultado do projeto para as operações e o acompanhamento da produção até se atingir a meta estabelecida.

Na empresa 6, é feita a medição dos critérios de prazo e custo dos projetos de P\&D. No entanto, a medição dos critérios de impacto sobre o negócio das associadas depende da utilização da tecnologia desenvolvida pelas associadas. A responsabilidade pela medição dos benefícios prometidos pela tecnologia é de responsabilidade do associado, mas a empresa tem grande interesse pela confirmação ou não dos resultados da pesquisa.

A tabela 16 ilustra os pontos observados nas empresas para definir, priorizar e medir os critérios de sucesso de seus projetos. 


\begin{tabular}{|c|c|c|c|c|c|}
\hline Empresa 1 & Empresa 2 & Empresa 3 & Empresa 4 & Empresa 5 & Empresa 6 \\
\hline
\end{tabular}

Tabela 16: Pontos observados nas empresas - categoria:critérios de sucesso do projeto 


\subsubsection{Adaptação da gestão - organização}

Nesta categoria, verificou-se um comportamento mais homogêneo entre as empresas estudadas. Dentro da classificação de projetos adotada por cada um, as empresas adotam uma abordagem formal de gestão para projetos considerados estratégicos. Isso ocorre mesmo em empresas que não tem uma metodologia padronizada uniforme de gestão de projetos, como a empresa 3 e a empresa 6.

$\mathrm{Na}$ empresa 1, apenas os projetos classificados como estratégicos na metodologia formal de classificação de projetos, são obrigados a seguir a metodologia formal de gestão de projetos. Para estes projetos existe um líder de projeto com dedicação integral e uma pessoa da equipe do PMO Estratégico assessora a gestão do projeto para assegurar a utilização da metodologia de gestão de projetos. Além disso, o projeto é revisado a cada 15 dias.

$\mathrm{Na}$ empresa 2, os projetos considerados estratégicos pelo Comitê de Planejamento Estratégico da unidade estudada são obrigados a seguir uma metodologia padronizada de gestão de projetos e são monitorados por uma área chamada de Tecnologia de Gestão. Os líderes de projeto não tem dedicação em tempo integral, mesmo nos projetos considerados estratégicos. $\mathrm{Na}$ empresa 3, não há uma metodologia padrão centralizada para toda a empresa. Conforme já foi dito, os projetos são geridos de acordo com o estilo gerencial dos líderes e executivos envolvidos, com diferentes níveis de formalização de processos e documentos. No entanto, existe uma iniciativa de organização da gestão de projetos inserida no contexto de um programa corporativo de mudança de cultura. É comum observar a dedicação integral de gestores em projetos considerados complexos.

A empresa 4 tem uma metodologia formal de gestão de projetos de engenharia. É utilizada a metodologia FEL (Front-End-Loading) para gestão das fases iniciais do ciclo de vida dos projetos. Na fase de implantação, é utilizada uma metodologia própria baseada no PMBOK (2004). Os níveis de formalização exigidos da gestão de projeto são rigorosos. Todos os projetos 
tem equipes dedicadas integralmente à gestão dos projetos. Os projetos complexos recebem assessoria para planejamento e monitoramento de um departamento interno da empresa.

A empresa 5 tem uma metodologia formal própria para gerir seus projetos. Baseada no modelo do PMBOK (2004), segundo os entrevistados, a metodologia atende bem a fase de implantação dos projetos. Percebeu-se uma insatisfação com o estado atual da gestão das fases iniciais do projeto, em função da falta de formalidade dos processos. Segundo os entrevistados, o modelo do PMBOK (2004) não atende as necessidades de estruturação destas fases iniciais dos projetos industriais da empresa.

A empresa 6 não tem metodologia formal padronizada para todos os seus projetos. Os diretores e coordenadores é que definem uma estrutura de organização dos projetos caso a caso, ou uma organização comum para todos os projetos de uma diretoria ou coordenadoria. Há um sistema formal de monitoramento de horas despendidas nos projetos, com objetivo de acompanhar os custos internos dos projetos.

A tabela 17 ilustra os pontos observados nas empresas na adaptação da organização do projeto ao tipo de projeto. 


\begin{tabular}{|c|c|c|c|c|c|}
\hline Empresa 1 & Empresa 2 & Empresa 3 & Empresa 4 & Empresa 5 & Empresa 6 \\
\hline
\end{tabular}

Tabela 17: Pontos observados nas empresas - categoria:adaptação da gestão - organização 


\subsubsection{Adaptação da gestão - gestão dos requisitos}

Nesta item procurou-se descrever como as empresas estudadas fazem a gestão dos requisitos do projeto. Em seguida foi observado se as descrições contemplam os elementos de preocupação descritos pelo modelo de Shenhar e Dvir (2007).

Percebeu-se que as incertezas relativas aos requisitos iniciais recebem algum tratamento pelas empresas em seus projetos estratégicos. Uma evidência disso é a prática comum entre as empresas quanto ao uso de protótipos de mercado para minimizar estas incertezas. Foi observado também práticas de pesquisa de mercado mais detalhadas, como o uso de grupos foco no lançamento de novos produtos ou serviços.

No entanto, não foi observado preocupação com o estabelecimento de tempos de contingência nos cronogramas dos projetos para absorver eventuais riscos relativos à alterações de requisitos nos projetos complexos.

Na empresa 1, nos cerca de 30 projetos que fazem parte do portfólio de projetos estratégicos, foi observado de 10 deles envolveram a utilização de extensas pesquisas de mercado junto aos consumidores. Observou-se também que é comum a utilização de protótipos de mercado em escala reduzida.

Na empresa 2, o portfólio de projetos estratégicos é limitado a 10 projetos por ano, em função do limite de capacidade da área de Tecnologia de Gestão, responsável pelo planejamento e acompanhamento desses projetos. Foi expressado pelo entrevistado, que o grau de inovação não é uma preocupação neste conjunto de projetos que integra o portfólio de projetos estratégicos. No entanto, percebeu-se que a prática de anualização dos projetos acaba sendo um procedimento que diminui a escala de escopo dos projetos.

$\mathrm{Na}$ empresa 3 observou-se práticas de gestão de requisitos na unidade estudada, ou seja, na área comercial. Apesar de não haver uma classificação formal de complexidade e incerteza na empresa, projetos considerados pelos gestores como complexo e que envolvam o cliente, utilizam práticas de 
minimização de incertezas no levantamento dos requisitos. Observou-se a utilização de pesquisas de mercado com empresas especializadas e a utilização de grupos foco quando do lançamento de novos conceitos de serviços no mercado. Além disso, verificou-se a prática comum de montagem de pilotos, com redução de escopo do projeto, para identificação e tratamento de riscos.

$\mathrm{Na}$ empresa 4 a gestão dos requisitos é uma preocupação constante nos projetos. Existe a preocupação com a duração da fase de concepção, onde são levantados os requisitos do projeto. Por se tratar de um portfólio de projetos que envolvem investimentos superiores a 100 milhões de dólares e envolvem um amplo leque de partes interessadas, a empresa tem a preocupação de dimensionar tempos adequados para envolvimento das partes interessadas, coleta de dados e as várias iterações necessárias para definir os objetivos do projeto.

$\mathrm{Na}$ empresa 5, existe uma preocupação com a falta de formalidade nos processos de levantamento dos requisitos. Observou-se que o tempo disponível para entender corretamente a necessidade não é bem dimensionado. Foi comentado pelos entrevistados que é comum haver aprovação de projetos sem ter sido feita ainda a documentação de formalização.

Na empresa 6 não há uma avaliação das dificuldades e riscos envolvidos na gestão dos requisitos dos projetos.

A Tabela 18 mostra os pontos observados em cada empresa na adaptação da gestão dos requisitos dos projetos. 


\begin{tabular}{|c|c|c|c|c|c|}
\hline Empresa 1 & Empresa 2 & Empresa 3 & Empresa 4 & Empresa 5 & Empresa 6 \\
\hline
\end{tabular}

Tabela 18: Pontos observados nas empresas - categoria:adaptação da gestão - gestão de requisitos 


\subsubsection{Adaptação da gestão - criação e construção do produto}

Nesta categoria, percebeu-se que as incertezas relativas à construção do produto não são tratadas no planejamento dos projetos. A quantidade de ciclos de design, os momentos de congelamento de especificações e design não foram citados pelos entrevistados nas empresas e também não foram observadas evidências destas práticas nas fontes secundárias desta pesquisa.

$\mathrm{Na}$ empresa 1, existe preocupação com o desenho do produto, serviço ou resultado final do projeto. Alguns dos projetos do portfólio envolvem o desenho e entrega de um novo processo. Vários desses processos envolvem atividades que serão feitas pela primeira vez na empresa. No entanto, o dimensionamento dos tempos de desenho e concepção do produto ou resultado não leva em consideração explicitamente os tempos necessários para ciclos de desenho ou os momentos de congelamento das especificações.

$\mathrm{Na}$ empresa 2, os projetos envolvem atividades que a empresa tem conhecimento técnico, diminuindo assim as incertezas associadas ao uso de tecnologias novas nos projetos. Por essa razão, diminui a necessidade de dimensionar os tempos da fase de concepção considerando eventuais ciclos de desenvolvimento e testes de tecnologias não conhecidas. Pela mesma razão, diminui a preocupação em dimensionamento de contingenciamentos para eventuais prorrogações de momentos de congelamento de especificações.

$\mathrm{Na}$ empresa 3, os projetos considerados complexos dentro da área comercial (e.g., criação de um serviço para um novo segmento de mercado) envolvem a construção de produtos e serviços. Esta construção envolve atividades feitas pela primeira vez, com uso de nova tecnologias, o que traz incertezas para a montagem de especificações para produtos, processos e tecnologias. Apesar das evidentes incertezas tecnológicas, não existe a explicitação e comunicação destas incertezas entre os patrocinadores e a equipe gerencial do projeto. O reflexo disto é que estimativas de tempos de desenho e 
concepção podem não refletir os inevitáveis ciclos de iteração e testes, levando a possíveis atrasos.

$\mathrm{Na}$ empresa 4, por se tratar de projetos focados em engenharia, existe uma cultura bem consolidada de desenho do produto. A empresa utiliza a metodologia FEL, que formaliza os procedimentos a serem seguidos durante a fase de conceituação e desenho do produto. Os tempos necessários para os ciclos de desenho e testes são embutidos nos prazos necessários para a realização desta fase do projeto, com prorrogação do momento de congelamento das especificações.

Na empresa 5, os projetos estão ligados também à engenharia. A unidade analisada da empresa é responsável pelo planejamento e monitoramento de todos os projetos ligados a área industrial da empresa no Brasil, América Latina e América do Norte. Apesar de não seguir uma metodologia de mercado (como o FEL), a empresa tem profissionais experientes e conhecedores em serviços de engenharia e tem procedimentos estabelecidos para desenvolvimento de desenho de produtos. Mesmo assim, observou-se manifestações de deficiências no processo. Os tempos são considerados muito curtos para o desenvolvimento de projetos que envolvam maior complexidade técnica. Apesar de observar-se atenção dos profissionais quanto ao dimensionamento de espaços de contingenciamento, estes espaços acabam não sendo respeitados na aprovação dos projetos.

$\mathrm{Na}$ empresa 6, a experiência e conhecimento da equipe técnica envolvida nos projetos da empresa acaba minimizando muitos dos riscos envolvidos durante a construção do resultado do projeto. No entanto, não foi observado a existência de análises formais das dificuldades técnicas envolvidas na construção dos projetos. As avaliações são informais, não estruturadas, e fortemente dependente da qualificação dos gestores envolvidos.

A Tabela 19 mostra os pontos observados nas empresas na adaptação da gestão de projetos em relação à criação e construção do produto. 


\begin{tabular}{|c|c|c|c|c|c|}
\hline Empresa 1 & Empresa 2 & Empresa 3 & Empresa 4 & Empresa 5 & Empresa 6 \\
\hline
\end{tabular}

Tabela 19: Pontos observados nas empresas - categoria:adaptação da gestão - criação e construção do produto 


\subsubsection{Adaptação da gestão - re-planejamento do projeto}

Nesta categoria, percebeu-se que três empresas têm um procedimento bem definido para monitoramento, revisão e atualização dos projetos. As demais fazem atualização, mas de maneira informal, condicionada ao estilo gerencial dos líderes do projeto.

Na empresa 1, os projetos classificados como estratégicos são monitorados e atualizados a cada 15 dias, sem perder a referência da base zero do projeto em termos de orçamento e cronograma. Existem fluxos bem definidos de operações de atualização e mudanças de projeto. O re-planejamento dos projetos pode ser motivado pelas revisões quinzenais ou por solicitações não programadas de alterações dos projetos. No entanto, existe um rigor formal para a repactuação do acordo do gestor de projetos com os patrocinadores através da revisão do plano do projeto.

$\mathrm{Na}$ empresa 2, os projetos seguem uma metodologia pré-definida da empresa. Nesta metodologia estão incluídos procedimentos para atualização e mudanças nos projetos, realizados em intervalos que variam de uma semana a um mês. Como os projetos são anualizados, a cada ano os projetos são avaliados e toma-se uma decisão pela sua continuidade ou não. Em função disso, a linha de base do cronograma e o orçamento base dos projetos são renovados a cada ano.

$\mathrm{Na}$ empresa 3, os projetos são geridos sem a utilização de uma metodologia de gestão de projeto unificada para a empresa. Em conseqüência, a atualização e a gestão de mudanças do projeto é um processo variável com o estilo de gestão de uma área ou de um ou mais líderes envolvidos no projeto. Nesta empresa, no departamento comercial, é comum observar a utilização de metodologias de gestão de projetos trazidas por empresas de consultoria contratadas.

$\mathrm{Na}$ empresa 4, os projetos são atualizados mensalmente, seguindo metodologia própria baseada no FEL e no PMBOK (2004). As alterações de projeto são originadas nas reuniões mensais regulares dos projetos ou em eventuais solicitações não programadas de alterações. O re-planejamento de 
projetos é usual em relação aos projetos de capital da empresa. Nas análises de re-planejamento, qualquer tomada de decisão utiliza o direcionador do projeto no momento de análise. Por exemplo, quando os preços do minério de ferro estavam em alta no mercado, o direcionador era o atendimento do prazo.

$\mathrm{Na}$ empresa 5 , os projetos são atualizados mensalmente, seguindo a metodologia própria da empresa, baseada no modelo do PMBOK (2004). O re-planejamento dos projetos é feito regularmente.

$\mathrm{Na}$ empresa 6, as atualizações de projeto não seguem uma programação específica. Os intervalos de atualização são feitos de acordo com os critérios de cada diretor e coordenador envolvidos no projeto. Existe o foco em questões técnicas na revisão dos projetos.

A Tabela 20 mostra os pontos observados em cada empresa na adaptação das práticas de re-planejamento. 


\begin{tabular}{|c|c|c|c|c|c|}
\hline Empresa 1 & Empresa 2 & Empresa 3 & Empresa 4 & Empresa 5 & Empresa 6 \\
\hline
\end{tabular}

Tabela 20: Pontos observados nas empresas - categoria:adaptação da gestão - re-planejamento 


\subsection{Contribuição das abordagens de gestão para o sucesso ou fracasso dos projetos complexos e incertos nas empresas}

Os resultados apresentados neste item referem-se à questão de pesquisa: "Como os aspectos observados de definição e gestão contribuem para o sucesso ou fracasso dos projetos?"

A análise desta questão gerou o segundo resultado deste trabalho (R2), mostrado na figura 1 no capítulo 2. Esse segundo resultado (R2) e o primeiro resultado (R1) geraram o outro resultado (R3) que é o entendimento, críticas e melhorias do modelo de gestão contingencial de Shenhar e Dvir (2007) (R3).

A análise das abordagens gerenciais utilizadas, nos quesitos observados, permitiu entender como cada empresa gerencia seus projetos complexos e observar práticas similares entre os estudos de caso. Neste item 6.2 procurou-se observar as similaridades das práticas das abordagens de cada estudo de caso para inferir a presença de práticas comuns e suas implicações para o sucesso ou fracasso dos projetos.

As similaridades em pelo menos três empresas observadas em cada quesito analisado estão apresentados na Tabela 20. Na mesma tabela, os números entre parênteses representam a quantidade de empresas que adotam o item discriminado.

Procurou-se observar os itens contidos no quadro teórico da pesquisa: identificação do tipo de projeto, definição e medição dos critérios de sucesso dos projetos e utilização de estratégias de adaptação da gestão em quatro sub-itens - organização, gestão de requisitos, criação e desenvolvimento do produto e re-planejamento.

\subsubsection{Identificação do tipo de projeto}

A contribuição para o sucesso dos projetos neste item vem do uso de um modelo formal de avaliação da complexidade e incerteza nos projetos. Segundo Shenhar e Dvir (2007), com um modelo formal, as empresas passam a ter disciplina para identificação de benefícios e riscos dos projetos, 
para criação de um conjunto de regras e comportamentos para cada tipo de projeto, para avaliação de disparidades entre os estilos gerenciais requeridos e para uniformização da comunicação entre executivos, equipes de projetos e clientes.

Segundo Shenhar e Dvir (2007), a identificação da complexidade e incerteza dos projetos vem do uso de um modelo de quatro dimensões. Cada projeto é posicionado em relação ao grau de inovação do resultado do projeto, ao grau de incerteza tecnológica envolvida, ao grau de complexidade do projeto, e ao grau de ritmo de execução a ser adotado em função do tempo disponível.

O posicionamento dos projetos em cada uma das quatro dimensões está associada a um conjunto de riscos. Quanto maior o grau de intensidade atribuído a cada dimensão, mais intensos são os riscos, com maior probabilidade de ocorrência e maior impacto sobre o projeto.

As práticas referentes à identificação do tipo de projeto mostram que as empresas estudadas diferenciam seus projetos. Observou-se um predomínio de diferenciações entre projetos estratégicos e não estratégicos, mas também observaram-se diferenciações por natureza técnica do projeto e diferenciação entre simples e complexo.

A diferenciação dos projetos em estratégico e não estratégico tem suporte nos estudos de Shenhar e Dvir (2007). Segundo os autores, a maneira mais fácil e efetiva de diferenciar inicialmente os projetos é através das metas de negócio envolvidas e através do tipo de consumidor ou cliente a ser atendido. As metas de negócio dividem os projetos em estratégicos ou operacionais. Os consumidores ou clientes são divididos em externos ou internos.

No entanto, conforme observa Shenhar e Dvir (2007), a classificação quanto a importância estratégica não seria suficiente para incutir nos executivos e equipes de projeto a disciplina necessária para identificação de benefícios e riscos dos projetos, para criação de um conjunto de regras e comportamentos para cada tipo de projeto, para avaliação de disparidades entre os estilos gerenciais requeridos e para uniformização da comunicação entre executivos, equipes de projetos e clientes. Com uma avaliação formal de complexidade e 
incerteza facilitada por um modelo estruturado, segundo Shenhar e Dvir (2007), estes objetivos poderiam ser atingidos.

No entanto, observou-se que apenas uma das empresas estudadas classifica a complexidade e incerteza de seus projetos formalmente. Nas demais empresas, observou-se que a questão da complexidade e incerteza dos projetos é levada em consideração nas análises, mas sem a utilização de nenhum modelo que possa ser universalizado. Além disso, as análises são informais e os resultados não ficam documentados.

Mesmo na análise inicial de posicionamento dos projetos entre estratégicos e não estratégicos, observou-se que algumas empresas utilizam processos informais de análise. Observou-se que nos processos formais, as dimensões utilizadas para classificação eram explícitas e se baseavam no volume de investimentos e no retorno financeiro. Nos processos informais, a decisão de classificação dependia do estilo gerencial do executivo e da equipe do projeto.

Outro ponto observado foi a falta de comunicação adequada sobre o tipo de projeto entre os executivos e as equipes de projeto. Observou-se em apenas uma das empresas a presença de um modelo de comunicação formal.

A falta de processos formais de análise e comunicação é um dos pontos levantados por Shenhar e Dvir (2007) para o mau desempenho dos projetos quanto ao atendimento de suas metas. A falta de formalidade pode levar à falta de entendimento dos executivos sobre a complexidade e incerteza dos projetos e também à comunicação deficiente entre os patrocinadores e as equipes de projeto.

\subsubsection{Critérios de sucesso}

A contribuição para o sucesso neste item, segundo Shenhar e Dvir (2007) vem do maior foco no negócio que uma análise multidimensional de sucesso pode trazer para os executivos e equipes de projeto e da atribuição de responsabilidade por todas as métricas de sucesso para o gerente de projeto. 
Além disso, segundo Shenhar e Dvir (2007), a contribuição para o sucesso vem da atribuição de pesos relativos aos múltiplos critérios, facilitada pela identificação da complexidade e da incerteza associada a cada projeto.

O foco no negócio foi observado nos casos estudados. Constatou-se que as empresas utilizam critérios multi-dimensionais para avaliar o sucesso ou fracasso dos projetos complexos. As dimensões mais observadas foram o atendimento dos prazos e dos custos de implantação, o atendimento das especificações de qualidade e o atendimento de metas de negócio, atendimento de metas operacionais e atendimento de metas de segurança no trabalho.

O modelo de Shenhar e Dvir (2007) sugere a utilização de cinco dimensões de sucesso dos projetos: eficiência, impacto no consumidor, impacto na equipe, impacto no negócio e preparação para o futuro. Nos casos estudados, as dimensões de impacto na equipe e de preparação de futuro não foram observadas diretamente nas empresas. No entanto, percebeu-se que existe preocupação com estes temas em algumas empresas. Nos impactos do projeto sobre a equipe, observou-se preocupação com políticas de incentivo e com aprendizado e transferência de conhecimento. Nos impactos sobre o futuro, uma das empresas avaliou que o desenvolvimento de um projeto de P\&D possibilitaria à empresa a opção de seguir para uma próxima etapa de desenvolvimento, que no médio e longo prazo, poderia levar a um produto comercial.

A utilização de métricas quantitativas nos critérios de sucesso parece predominar entre as empresas. Apenas uma das empresas mostrou grande dificuldade em estabelecer métricas quantitativas em seus projetos de pesquisa e desenvolvimento. No entanto, apesar de utilizar métricas quantitativas, percebeu-se dificuldades no estabelecimento de responsabilidades e na medição dos critérios de sucesso.

Estas duas dificuldades são citadas nos estudos de Shenhar e Dvir (2007) e foram observadas nos casos estudados. Em relação à responsabilidade, percebeu-se que esse é um ponto nebuloso nas empresas. Em algumas empresas observou-se que a responsabilidade do gestor do projeto se limita 
ao ciclo de vida definido. Isso acaba limitando a utilização de algumas métricas de sucesso relacionadas à contribuição para o sucesso do negócio.

\subsubsection{Adaptação da gestão}

A contribuição para o sucesso neste item, segundo Shenhar e Dvir (2007), vem da definição ou redefinição da organização, processos, planos, atividades e equipe de um projeto, feitas pelos executivos conforme o tipo de projeto.

Em relação às estratégias de adaptação, observa-se, nos casos estudados que tem uma metodologia de gestão de projetos, que parece haver uma correlação entre a classificação entre projeto estratégico ou não estratégico e algumas práticas observadas.

Nos projetos estratégicos há um nível de formalidade e padronização exigido na gestão, com procedimentos e documentações exigidos nas etapas de planejamento e controle desses projetos. Segundo Shenhar e Dvir (2007) existe uma associação de projetos estratégicos a uma maior complexidade, o que exige maiores esforços de coordenação e de formalização da gestão.

Nos projetos considerados estratégicos, percebeu-se que as empresas costumam alocar os gestores em tempo integral, exceção a duas das empresas estudadas que não adotam esta prática. Outro ponto observado foi a presença de escritórios de projeto para apoiar os gestores no planejamento e no controle dos projetos, exceto duas das empresas estudadas.

Como já foi observado no item 6.7.1, apenas uma empresa utiliza um tipo de avaliação formal da complexidade e da incerteza dos projetos. No entanto, apesar de não utilizarem nenhum modelo formal, as demais empresas adotam várias estratégias adaptativas na gestão de seus projetos.

Em relação à gestão dos requisitos, que tem papel crítico em projetos de alto grau de inovação, parece ser prática comum nas empresas a utilização de protótipos de mercado ou pilotos para reduzir as incertezas envolvidas na captação dos requisitos do projeto. Além da prática de uso de pilotos, Shenhar e Dvir (2007) sugerem o uso de pesquisas quantitativas e qualitativas e prorrogação de pontos de congelamento dos requisitos. 
Segundo os entrevistados das empresas que lançam produtos no mercado, o uso de pesquisas de mercado é amplamente utilizado para identificar as necessidades dos consumidores e traduzí-las em requisitos do projeto.

Observou-se um tratamento heterogêneo em relação às contingências dos projetos complexos e incertos. Conforme Shenhar e Dvir (2007), os tempos de contingenciamento são usados para tratar as incertezas relativas à gestão de requisitos e à criação e construção do produto do projeto. Três das empresas dimensionam os cronogramas de seus projetos complexos e incertos levando em consideração tempos de contingenciamento.

Outra prática observada nas empresas foi a avaliação das competências técnicas internas para realizar um projeto. Segundo Shenhar e Dvir (2007) esta prática esta associada à identificação das incertezas tecnológicas do projeto. No entanto, não foi observado nas empresas um cuidado com o dimensionamento dos tempos necessários para criar e construir o produto do projeto levando em conta as possibilidades de falhas e a necessidade de ciclos de desenvolvimento e testes.

Outro ponto de atenção sugerido por Shenhar e Dvir (2007) é contemplado parcialmente nas empresas estudadas. Trata-se do cuidado com a gestão de mudanças e no replanejamento dos projetos. Nos projetos complexos e incertos, as metas e escopo iniciais estão submetidos a incertezas que vão sendo dissipadas à medida que o projeto avança. Nesta condições, os projetos passam por mudanças que precisam ser feitas levando em consideração os critérios multi-dimensionais do projeto.

Nas metodologias formais que os projetos estratégicos devem seguir nas empresas, observou-se a existência de procedimentos bem definidos para gestão de mudanças nos projetos. Os intervalos de monitoramento dos projetos também são definidos previamente, exceto duas das empresas que não tem uma metodologia formal de gestão de projetos.

A percepção neste ponto é sobre a eventual falta de flexibilidade das metodologias das empresas no tratamento das mudanças nos projetos. Em uma das empresas, um executivo manifestou preocupação em relação à rigidez metodológica nos projetos de pesquisa e desenvolvimento. $O$ 
comentário foi que se for necessário seguir a metodologia a risca em qualquer mudança de projeto, os pesquisadores líderes de projeto despenderiam mais tempo formalizando ações do que realmente trabalhando em seus projetos.

A Tabela 21 mostra os pontos de convergência observados nas empresas. 


\begin{tabular}{|c|c|}
\hline Quesito & Pontos em comum nos casos \\
\hline $\begin{array}{l}\text { Identificação do tipo de } \\
\text { projeto }\end{array}$ & $\begin{array}{l}\text { - Diferenciação entre projetos estratégicos e não estratégicos (4) } \\
\text { - } \text { Diferenciação entre projetos conforme a natureza técnica (1) } \\
\text { - } \text { Diferenciação informal dos projetos em simples e complexos (1) } \\
\text { - Diferenciação em dimensões explícitas (2) } \\
\text { Diferenciação não é comunicada entre os patrocinadores e as equipes de } \\
\text { - } \quad \text { pifojeto (5) } \\
\text { projeto (1) } \\
\text { Não há identificação formal de complexidade e incerteza dos projetos (5) }\end{array}$ \\
\hline $\begin{array}{l}\text { Critérios de sucesso e } \\
\text { fracasso }\end{array}$ & $\begin{array}{l}\text { - Utiliza critérios multidimensionais para definir sucesso dos projetos (6) } \\
\text { - Não define formalmente o peso de cada dimensão de sucesso (4) } \\
\text { - Utiliza métricas quantitativas (5) } \\
\text { - } \quad \text { Gedição do sucesso é feita dentro do ciclo de vida do projeto (4) } \\
\text { do projeto (4) }\end{array}$ \\
\hline Organização & $\begin{array}{l}\text { - Utiliza metodologia própria referenciada em modelos conhecidos (4) } \\
\text { - } \quad \text { Projetos estratégicos seguem metodologia formal (4) } \\
\text { - } \quad \text { Gerente dedicado integralmente a cada projeto estratégico (4) } \\
\text { - } \quad \text { Apoio de escritórios de projeto nos projetos (4) }\end{array}$ \\
\hline Gestão de requisitos & - Utiliza protótipos de mercado para minimizar riscos (4) \\
\hline $\begin{array}{l}\text { Criação e Construção do } \\
\text { produto }\end{array}$ & $\begin{array}{l}\text { - Tempos de contingenciamento não são dimensionados (3) } \\
\text { - Avaliam competência interna para o projeto (5) }\end{array}$ \\
\hline $\begin{array}{l}\text { Re-planejamento do } \\
\text { projeto }\end{array}$ & $\begin{array}{l}\text { - } \quad \text { Atualização do projeto em intervalos pré-determinados (4) } \\
\text { - } \quad \text { Controle formal de mudanças no projeto (3) }\end{array}$ \\
\hline
\end{tabular}

Tabela 21: Pontos de convergência observados nas empresas 


\subsection{Análise crítica da abordagem de Shenhar e Dvir (2007), no contexto das empresas estudadas}

Considerando os resultados da análise dos casos, as críticas da abordagem contingencial estruturada de Shenhar e Dvir (2007) são descritas a seguir.

Conforme foi observado nos estudos de caso, apenas uma empresa identifica formalmente a complexidade e incerteza envolvidas no início do projeto. Certamente, o modelo de identificação de projetos sugerido na abordagem de Shenhar e Dvir (2007) ajudaria a disciplinar a análise de benefícios e riscos envolvidos nos projetos complexos e incertos. No entanto, uma questão a ser levantada durante a identificação das dimensões de inovação, tecnologia, complexidade e ritmo é como relativizar o grau de intensidade de cada dimensão dentro de uma mesma empresa.

Por exemplo, comparando dois projetos de uma empresa. Um dos projetos é da área de marketing e outro da área de produção. Ambos foram classificados, dentro das respectivas áreas, como de alta inovação. Numa eventual decisão para incluir num portfólio de projetos, qual dos dois projetos tem maior inovação? A abordagem de Shenhar e Dvir (2007) não trata esta questão.

Ainda em relação à identificação de complexidade e incerteza, num projeto de grande porte poderiam existir classificações distintas em diferentes partes do projeto. Shenhar e Dvir (2007) usam o projeto do aeroporto de Denver nos Estados Unidos para exemplificar um subdimensionamento da dimensão de tecnologia. O sistema de bagagem envolvia alta tecnologia enquanto o aeroporto envolvia baixa tecnologia. O subdimensionamento da dimensão tecnológica de uma parte do projeto levou a prorrogações sucessivas na data de inauguração do aeroporto. Este exemplo levanta a questão sobre quantas diferentes classificações deveriam ser feitas num mesmo projeto. A abordagem de Shenhar e Dvir (2007) não trata explicitamente esta questão.

Em relação às responsabilidades e incentivos pelos resultados dos projetos, Shenhar e Dvir (2007) argumentam que o gerente de projeto deve ter responsabilidade sobre os critérios e metas multidimensionais de sucesso dos projetos. Ou seja, o gerente de projetos não deve responder somente 
pela implantação do projeto no prazo, no custo e dentro das especificações de qualidade. Apesar de reconhecerem as dificuldades de recompensar ou penalizar gerentes de projetos por resultados de negócio que podem vir muito tempo depois do término do projeto, Shenhar e Dvir (2007) argumentam que a adoção da abordagem adaptativa de gestão levaria a mudanças organizacionais que tratariam essa questão em busca de uma solução.

No entanto, a análise dos estudos de caso indicam que as empresas que utilizam várias estratégias adaptativas em seus projetos ainda consideram que a responsabilidade do gerente de projetos deveria ficar dentro do ciclo de vida do projeto. Essa constatação levanta dúvidas sobre a predisposição das empresas para realização de mudanças organizacionais para tratar essa questão.

Ainda em relação aos critérios de sucesso, a análise multidimensional é parte importante da abordagem de Shenhar e Dvir (2007), sugerindo utilização de métricas de curto e longo prazo nos projetos. No entanto, os dados dos estudos de caso sugerem dificuldades de ordem prática em considerar critérios de longo prazo nos projetos. Observou-se que apesar de utilizarem critérios multidimensionais na avaliação de seus projetos, as empresas evitam a inclusão de critérios de longo prazo, pois muitas vezes não conseguem estabelecer métricas e também pela razão já citada quanto às atribuições de responsabilidades do gerente de projeto.

Outro ponto de atenção da abordagem de Shenhar e Dvir (2007) é a incorporação das práticas gerenciais nas metodologias existentes. Ao observar os estudos de caso, percebeu-se que várias empresas utilizam metodologias próprias para gestão de seus projetos estratégicos. No entanto, não existe uma diferenciação explícita dos projetos estratégicos quanto a complexidade e incerteza de cada um.

Essa subclassificação poderia criar várias linhas de metodologias a serem aplicadas aos projetos. Apesar deste ponto ser um dos pilares da abordagem de Shenhar e Dvir (2007), se não for tratado com cuidado, existe o risco de se criar um excesso de burocracia, com várias alternativas de metodologia formal conforme o tipo de projeto. A materialização deste risco contrariaria 
um dos propósitos iniciais da abordagem de Shenhar e Dvir (2007) que era aumentar a eficiência e eficácia do processo de gestão de projetos.

Do ponto de vista acadêmico, a abordagem de Shenhar e Dvir (2007) é fundamentada em pesquisas realizadas ao longo de 15 anos de estudos dos dois autores. Além disso, foram incorporadas na abordagem a contribuição de outros autores. A justificativa para proposição da nova abordagem se apoiou em trabalhos de autores que criticam as abordagens tradicionais de gestão de projetos pela sua falta de flexibilidade e excessiva normatização, como Morris (1994) e Williams (2005).

Na identificação dos tipos de projetos, a abordagem de Shenhar e Dvir (2007) se apóia em trabalhos de autores na área de desenvolvimento e inovação de produtos, na área da teoria dos sistemas e na área de gestão da complexidade, como Wheelright e Clark (1992), como Christensen e Raynor (2003), como Boulding (1956) e como Eisenhardt e Brown (1997). Por exemplo, a classificação de grau de inovação no desenvolvimento de produtos de Wheelright e Clark (1992) é utilizada para classificar os projetos na dimensão de inovação do modelo proposto para identificar e classificar os projetos.

Na proposição sobre critérios de sucesso, a abordagem de Shenhar e Dvir (2007) se apóia em trabalhos de autores que discutem modelos multidimensionais para avaliação de sucesso, como Pinto e Slevin (1988) e Kaplan e Norton (1996).

$\mathrm{Na}$ adaptação dos estilos gerenciais aos tipos de projetos, a abordagem de Shenhar e Dvir (2007) se apóia em trabalhos nos mesmos temas utilizados na identificação dos projetos e também em trabalhos que tratam a gestão tradicional de projetos, como o PMBOK (2004). Esse resgate das abordagens tradicionais servem como ponto de sustentação da abordagem contingencial estrutura de gestão de projetos no objetivo da generalização, ou seja, aproveitar os pontos fortes da abordagem tradicional, que é a padronização, e acrescentar modificações vindas da gestão contingencial.

Apesar da lógica consistente do argumento proposto na abordagem de Shenhar e Dvir (2007), não foram apresentadas evidências empíricas sobre 
os efetivos benefícios da aplicação da abordagem nos projetos complexos e incertos nas empresas. Ou seja, a abordagem ainda não foi testada no campo, para que se pudesse aferir resultados.

As conclusões sobre o benefício da abordagem são inferências apoiadas na premissa de que projetos geridos de maneira contingencial têm maior chance de sucesso. Os exemplos de projeto utilizados no livro que apresenta a abordagem mostram situações de fracasso e sucesso para inferir que a aplicação da abordagem teria limitado as chances de fracasso e que o sucesso ocorreu devido à abordagem contingencial de gestão que foi aplicada nos projetos. 


\section{Capítulo 7}

\section{Conclusões}

Os projetos fazem parte da gestão estratégica das empresas na criação e sustentação de suas vantagens competitivas. O portfólio de projetos das empresas é composto por iniciativas relacionadas à busca de inovação e eficiência que envolvem diferentes graus de complexidade e incerteza.

Dado o comprovado mau desempenho dos projetos de maneira geral, amplificado pelo maior número de projetos considerados complexos e incertos, novas abordagens de gestão de projetos surgiram em contraponto à abordagem convencional.

As abordagens convencionais e as novas abordagens têm pontos positivos e negativos. As abordagens convencionais buscam a universalização através da padronização e da normatização de procedimentos e técnicas. As novas abordagens buscam a flexibilidade e maior adequação dos procedimentos e técnicas aos diferentes níveis de complexidade e incerteza dos projetos.

Entre as abordagens novas, a abordagem contingencial estruturada de Shenhar e Dvir (2007) procura aliar os pontos fortes da abordagem convencional com características de maior flexibilidade, propondo um modelo de identificação de tipos de projetos conforme suas graduações de complexidade e incerteza, medidas através de quatro dimensões: grau de inovação, grau de incerteza tecnológica, grau de complexidade e intensidade do ritmo necessário.

Avaliar a abordagem contingencial estruturada de Shenhar e Dvir (2007) no contexto de projetos complexos e incertos de empresas que atuam no Brasil é um dos objetivos deste trabalho. Para tanto, foi mostrada uma análise da abordagem de gestão de projetos complexos e incertos em empresas no 
Brasil. Tal análise foi baseada em seis estudos de casos, utilizados como unidades de investigação das questões de pesquisa levantadas.

As conclusões apresentadas neste capítulo referem-se aos principais tópicos levantados na pesquisa. Cada um dos tópicos se referem às questões de pesquisa: "Como são definidos e geridos os projetos complexos e incertos em empresas que atuam no Brasil?" e "Como os aspectos observados de definição e gestão contribuem para o sucesso ou fracasso dos projetos?"

Portanto, serão mostradas algumas considerações e observações finais deste estudo, considerações essas, relacionadas aos objetivos do trabalho. Ainda neste capítulo, serão feitas algumas recomendações para pesquisas futuras.

\subsection{Dinâmica de definição e gestão de projetos complexos e incertos e suas contribuições para o sucesso ou fracasso de projetos}

A pesquisa observou a dinâmica de gestão dos projetos complexos e incertos em alguns itens específicos, definidos através da revisão bibliográfica que resultou no referencial teórico da pesquisa. Os itens foram agrupados em definição do tipo de projeto, critérios de sucesso e adaptação da gestão.

A análise das informações mostrou a predominância de várias práticas nas seis empresas estudadas e a ausência de outras práticas que constam do modelo teórico da pesquisa. Foi observado também uma série de práticas presentes em todas as empresas ou em subconjuntos de no mínimo três empresas. Da mesma forma, as ausências de práticas também foram constatadas em todas as empresas ou em parte delas. Esta análise está consolidada na tabela 21, do capítulo 6.

No item identificação do tipo de projeto, observou-se, nas empresas, a predominância da falta de uma avaliação formal de complexidade e incerteza dos projetos, sejam estratégicos ou não. Como contribuição para o sucesso ou fracasso, a ausência de uma avaliação formal de complexidade aumenta as chances de escolha de estratégias inadequadas de gestão dos projetos e de escolha inadequada do direcionador de sucesso do projeto entre as diferentes dimensões de sucesso. 
No item de critérios de sucesso, observou-se, nas empresas, a utilização de critérios multi-dimensionais, com maior foco em métricas de tempo, custo, qualidade e de negócio. Além disso observou-se a predominância de uso de critérios que possam ser medidos dentro do ciclo de vida dos projetos. Como contribuição para o sucesso ou fracasso, a limitação de uso de critérios de sucesso apenas dentro do ciclo de vida do projeto pode levar a empresa a focar o curto prazo em detrimento do longo prazo quando da tomada de alguma decisão de mudança no projeto.

No item de adaptação da gestão aos tipos de projeto, observou-se que apesar da falta de uma avaliação formal de complexidade e incerteza, as empresas adotam várias estratégias de gestão que mitigam vários riscos de projetos complexos e incertos. Observou-se também o pouco uso de análises de contingenciamento e a predominância de uma metodologia única para todos os projetos estratégicos. As contribuições para o sucesso ou fracasso são a falta de espaços contingenciais nos cronogramas e orçamentos para absorção de eventuais riscos que se materializem em problemas e a falta de flexibilidade da metodologia aplicada em projeto levando a excessiva burocratização de projetos e baixa velocidade nas tomadas de decisão.

\subsection{Entendimento, crítica e aprimoramento da abordagem de Shenhar e Dvir (2007)}

Os estudos de caso permitiram uma análise crítica da abordagem de Shenhar e Dvir (2007) no ambiente de projetos complexos e incertos nas empresas. As conclusões foram as seguintes:

Primeiro, na identificação da complexidade e incerteza existe um problema relacionado à relatividade de graduações nas dimensões propostas pelo modelo. Entre dois projetos de áreas diferentes e que tenham a mesma graduação numa dimensão, não há como distinguir um projeto do outro. Este ponto pode se tornar mais crítico se o modelo for utilizado para selecionar ou priorizar os projetos num portfólio. Ainda em relação à identificação, foi colocado a falta de clareza em relação à possibilidade de existirem classificações diferentes de complexidade e incerteza para diferentes partes do projeto. 
Segundo, em relação aos critérios multidimensionais de sucesso dos projetos, as mudanças organizacionais necessárias para ampliar as responsabilidades do gerente de projeto parecem pouco prováveis nas empresas estudadas, levantando a questão sobre a viabilidade de tal ampliação. Uma das razões alegadas pelas empresas é a dificuldade de integração de metas entre o gerente de negócio, o gerente de projeto e o gerente das operações quanto ao sucesso do projeto. A temporariedade da função de gestor de projetos é predominante nas empresas estudadas. Para complicar mais, em algumas das empresas estudadas, uma ou mais fases de projetos complexos e incertos são gerenciadas por consultorias externas.

Terceiro, ainda em relação aos critérios multidimensionais de sucesso dos projetos, enquanto a abordagem de Shenhar e Dvir (2007) apregoa o foco em resultados multidimensionais de projetos no curto e longo prazo, as empresas estudadas utilizam critérios de sucesso que se encaixam no ciclo de vida que termina com a implantação do projeto. Consequentemente, o foco no curto prazo pode levar a desbalanceamentos nos portfólios de projetos das empresas, com predominância de iniciativas com possibilidade de resultados mais rápidos. A escassez de projetos com possibilidade de resultados no médio ou longo prazo pode ameaçar as vantagens competitivas das empresas.

Quarto, na adaptação da metodologia das empresas para gerir os projetos de acordo com os tipos identificados, percebeu-se nas empresas estudadas algum receio de burocracia excessiva, com múltiplas linhas de metodologia. A conseqüência disso seria a diminuição da eficiência dos processos, com possíveis prazos mais longos e custos maiores.

Portanto, a seguir são apresentadas sugestões para melhorar a abordagem contingencial estruturada de Shenhar e Dvir (2007).

Em relação ao modelo de identificação do tipo de projeto, a questão de relativização da intensidade atribuída a diferentes projetos em cada uma das dimensões poderia ser resolvida através da atribuição de pesos com a importância estratégica dos projetos. Por exemplo, considere uma comparação de um projeto inovador da área de marketing com um projeto 
inovador da engenharia, ambos com grau máximo de inovação no modelo de identificação de projetos da abordagem de Shenhar e Dvir (2007). Aquele que tivesse o maior peso estratégico, sendo o peso definido através da análise de critérios pré-definidos, seria o projeto considerado como de maior grau de inovação.

Ainda em relação ao modelo de identificação dos projetos, outra crítica à abordagem de Shenhar e Dvir (2007) foi a falta de clareza em relação à possibilidade de existirem classificações diferentes de complexidade e incerteza para diferentes partes do projeto. Este ponto poderia ser melhor considerado houvesse uma classificação inicial entre programa e projeto. Um programa definido como um agrupamento de projeto relacionados gerenciados de maneira coordenada para obter benefícios e controle que não seria possível se cada projeto fosse gerido individualmente (PMBOK, 2004). Cada um desses projetos que compõe o programa poderia ter uma classificação diferente nas dimensões de inovação, tecnologia, complexidade e ritmo. Portanto, não faria sentido uma classificação para o programa todo e sim para cada um de seus projetos.

Em relação à utilização de critérios muldimensionais de sucesso dos projetos, uma crítica foi a falta de clareza e orientação sobre como proceder nas atribuições de responsabilidades pelo sucesso dos projetos. A premissa de que mudanças organizacionais provocadas pela adoção da abordagem contingencial levariam a uma solução é muito geral, imprecisa e não pareceu gerar entusiasmo nas empresas estudadas. Uma orientação mais clara poderia ajudar na motivação das empresas, tal como a criação de um plano de incentivos de resultados de negócios que contemplasse os diversos agentes do projeto. Por exemplo, considere um projeto de lançamento de produto que contemplasse as áreas de marketing na conceituação, a área de engenharia na implantação da nova linha de produção e as áreas de operações e vendas na produção e comercialização do produto. Ao estabelecer os critérios de sucesso do projeto logo em seu início, cada uma dessas áreas teriam metas atreladas ao sucesso dos projetos. Ou seja, o gerente da implantação do projeto teria suas metas atreladas ao 
cumprimento dos prazos e custos, mas também atreladas ao sucesso do resultado do projeto.

Ainda em relação aos critérios multidimensionais, a constatação do viés de utilização de critérios de curto prazo para o sucesso de projetos entre as empresas estudadas parece ser provocada pela dificuldade em quantificar os critérios de longo prazo, além de estar ligado à discussão do parágrafo anterior sobre as responsabilidades integradas. Na questão da quantificação dos critérios, a exigência de uma formalização de atribuições de métricas e metas quantificáveis para autorização dos projetos poderia ajudar a provocar a discussão, podendo até mesmo motivar a maior integração dos agentes envolvidos e a atribuição de responsabilidades comparrtilhadas.

Em relação à adaptação da metodologia tradicional aos projetos, uma crítica foi o risco de burocratizar excessivamente a gestão dos projetos. Um maneira de evitar isso seria através da criação de agrupamentos limitados de variações metodológicas. As variações possíveis dentro dos agrupamentos seriam tratadas conforme decisões dos patrocinadores e gerentes de projeto. Por exemplo, considere uma empresa que divide a metodologia dos seus projetos de maneira similar a algumas das empresas estudadas: metodologia para projetos estratégicos, metodologia para projetos de melhorias sistêmicas, metodologia para projetos de melhorias locais. Dentro da metodologia para projetos estratégicos certamente existem variações quanto à necessidade de uso de técnicas e ferramentas, documentações e formalizações de planos e controles. A decisão de usar esta ou aquela técnica, ou esta ou aquela documentação seria delegada ao patrocinador ou comitê de projetos em conjunto com o gerente de projetos.

\subsection{Recomendações para pesquisas futuras}

O trabalho envolvido no desenvolvimento desta tese permitiu observar algumas carências de estudos mais aprofundados e também levantar algumas questões que não puderam ser estudadas neste trabalho, mas que poderiam ser objeto de estudos futuros. 
Uma pesquisa interessante seria sobre o tema de responsabilidades sobre 0 sucesso dos projetos. A abordagem de Shenhar e Dvir (2007) destaca a importância de atribuir responsabilidade mais ampla ao gerente de projetos, mas não diz como fazer isso.

No ítem anterior foi apresentada uma recomendação para a criação de um plano de incentivos compartilhados. No entanto, esta recomendação apenas indica um caminho a seguir, sendo necessários estudos adicionais para investigar melhor esta questão. Na literatura revisada neste trabalho percebeu-se que a questão dos critérios de sucesso dos projetos e as responsabilidades dos diversos agentes ainda é um tema polêmico. Esta percepção foi corroborada nos estudos de caso deste trabalho, com observações discrepantes entre os diversos entrevistados nas empresas. Além disso, um eventual estudo sobre esse assunto deveria contemplar também a questão da integração de metas e responsabilidades pelo sucesso dos projeto quando há agentes executores sob contrato, como consultorias, construtoras, entre outros.

Não foi objeto deste estudo a aplicação da abordagem contingencial estruturada de Shenhar e Dvir (2007) e a verificação dos seus resultados. Portanto, um estudo complementar poderia ser a investigação dos resultados de um implantação desta abordagem numa ou mais empresas. Por se tratar de uma abordagem recente, somente nos próximos anos será possível fazer tal investigação. Um trabalho de campo empírico com objetivo de verificar a efetividade da abordagem de Shenhar e Dvir (2007) ajudaria a elucidar alguns pontos ainda obscuros ou pouco detalhados do modelo de identificação de tipo de projeto, do modelo de critérios multidimensionais de sucesso dos projetos e das estratégias de adaptação. 


\section{Capítulo 8}

\section{Referências bibliográficas}

ATKINSON, R. Project management: cost, time and quality, two best guesses and a phenomenon, it is time to accept other success criteria. International Journal of Project Management V.17, N. 6, pp. 337-342, 1999

BOOTH, W.; COLOMB, G.G.; WILLIAMS, J.M. The craft of research. The University of Chicago Press, 1995

BLACK, KEN - Causes of project failure: a survey of professional engineers PM Network Nov/96 pp 21-24

BOULDING, K.E. General system theory: the skeleton of science. Management Science, 1956.

BRYDE, DAVID J. Project management concepts, methods and application. International Journal of Operations \& Production Management, 2003;23;7/8

CHAOS REPORT. The Standish Group Report, 1995. Disponível em http://www.scs.carleton.ca/ beau/PM/Standish-Report.html

CHRISTENSEN, C.L.; RAYNOR, M.E. The innovator's solution. Harvard Business School Press, 2003.

CICMIL, S. Understanding project management practice through interpretative and critical research perspectives. Project Management Journal; Jun 2006; 37,2

CLELAND, D.I. Project management: strategic design and implementation. Second edition. McGraw-Hill, 1994

DONK, D. P. VAN; MOLLOY, E. From organising as projects to projects as organizations. International Journal of Project Management 26 (2008) 129137 
DVIR, D.; LIPOVETSKY, S.; SHENHAR, A.J.; TISHLER, A. In search of project classification: a non-universal approach to project success factors. Research Policy, Vol. 27, Issue 9, December 1998.

DVIR, D.; RAZ, T; SHENHAR, A.J. An empirical analysis of the relationship between project planning and project success. International Journal of Project Management, Vol. 21, Issue 2, February 2003.

EISENHARDT, K.M. Building theory from case study research. Academy of Management Review, 1989 vol. 14, n. 4, pp 532-550.

EISENHARDT, K.M.; TABRIZI, B.N. Accelerating adaptative processes: product innovation in the global computer industry. Administrative Science Quarterly, 40 (1995): 84-110

EISENHARDT, K.M; BROWN, S.L. The art of continuous change: linking complexity theory and time-paced evolution in relentlessly shifting organizations. Administrative Science Quarterly, 42 (1997).

FICHTER, D. Why web projects fail. Online, July/August 2003

HALLGREEN, M; MAANINEN-OLSSON, E. Deviations, ambiguity and uncertainty in a project-intensive organization. Project Management Journal; Sep 2005; 36, 3

HARTMAN, F. Preparing the mind for dynamic management. International Journal of Project Management 26, 2008

HARTMAN, F.; ASHRAFI, R. Project Management in the information technology/information systems industy. Project Management Journal 33 (3), 2002.

KPMG. Programme management survey. U.K., KPMG, 2002

HOGDSON, D. Disciplining the professional: the case of project management. Journal of Management Studies 39:6 September 2002

JAAFARI, A. Project Management in the age of complexity and change. Project Management Journal, 34 (4) December 2003

KAPLAN, R.S.; NORTON, D.P. The Balanced Scorecard, Harvard Business School Press, 1996 
KERZNER, H. Applied project management: best practices on implementation. Wiley, 2000

KLOPPENBORG, TJ.; OPFER, W.A. Forty years of project management research: trends, interpretations, and predictions. In The frontiers of project management research. Project Management Institute, 2002.

KREINER, K. In search of relevance: project management in drifting environments. Scandinavian Journal of Managament. Vol. 11, No 4, pp 335346, 1995

LEYBOURNE, S.A. The changing bias of project management research: a consideration of the literatures and an application of extant theory. Project Management Journal; Mar 2007; 38,1.

LIPOVETSKY, S.; TISHLER, A.; DVIR, D.; SHENHAR, A.J. The relative importance of project success dimensions. R\&D Management, Vol. 27, Issue 2, December 2002.

MARQUES JUNIOR, L.J. Uma contribuição para melhoria do planejamento de empreendimentos de construção em organizações públicas. Dissertação de Mestrado, Escola Politécnica da Universidade de São Paulo, 2000

MAYLOR, HARVEY. Beyond the Gantt Chart: Project Management Moving On. European Management Journal, Vol 19, 2001

MIDLER, C. Project management for intensive, innovation-based strategies: new challenges for the $21^{\text {st }}$ century. In The frontiers of project management research. Project Management Institute, 2002.

MILLS, B.; LANGDON, A; KIRK, C.; SWAN, J. Managing Technological Innovation Projects: the Quest for a Universal Language. In The Frontiers of Project Management Research. Project Management Institute, 2002

MILLS, B; LANGDON, A; KIRK, C.; SWAN, J. Managing technological innovation projects: the quest for a universal language. In The frontiers of project management research. Project Management Institute, 2002.

MORRIS, P.W.G. The management of projects. Thomas Telford, 1994 
MURIITHI, N; CRAWFORD, L. Approaches to project management in Africa: implications for international development projects. International Journal of Project Management 21 (2003)

PACKENDORFF, JOHANN. Inquiring into the temporary organization: new directions for Project management research. Scandinavian Journal of Management, Vol 11 No 4, 1995

PICH, M.T; LOCH, CHRISTOPH; MEYER, A.DE. On uncertainty, ambiguity, and complexity in project management. Management Science; August 2002; 48; 8.

PINTO, J.K.; SLEVIN, D.P. Project Success: definitions and measurement techniques. Project Management Journal, Vol 19 (1) February, 1988

PMBOK. A guide to the project management body of knowledge. Project Management Institute, 2004

PMI. Web site do Project Management Institute (www.pmi.org). Acessado em outubro de 2007

RAZ, T; SHENHAR, A.J.; DVIR, D. Risk management, project success, and technological uncertainty. R\&D Management, Vol 32, Issue 2, Dec 2002.

SHENHAR, A.J. From theory to practice: toward a typology of project management styles. Engineering Management Transactions, IEEE, Feb 1998 SHENHAR, A.J. One size does not fit all projects: exploring classical contingency domains. Management Science, Vol. 47, No. 3, March 2001.

SHENHAR, A.J. Strategic project management: the new framework. Portland International Conference on Management of Engineering and Technology, 1999.

SHENHAR, A.J.; Dvir, D. Toward a typological theory of project management. Research Policy, Vol. 25, Issue 4, June 1996.

SHENHAR, A.J.; DVIR, DOV. Reinventing Project Management: the diamond approach to successful growth and innovation. Harvard Business School Press, 2007 
SHENHAR, A.J.; TISHLER, A.; DVIR, D.; LIPOVETSKY, S.; LECHLER, T. Refining the search for project success factors: a multivariate, typological approach. R\&D Management, Vol. 32, Issue 2, December 2002.

SHENHAR, A.J; DVIR, D.; LEVY, O.; MALTZ, A.C. Project Success: a multidimensional strategic concept. Long Range Planning, Vol. 34, Issue 6, December 2001.

SMYTH, H.J.; MORRIS, P.W.G. Na epistemological evaluation of research into projects and their management: methodological issues. International Journal of Project Management 25 (2007)

SOMMER, S.C., LOCH, CHRISTOPH. Selectionism and learning in projects with complexity and unforeseeable uncertainty. Management Science, Vol 50, No 10, October 2004.

TATIKONDA, M.V.; ROSENTHAL, S.R. Technology novelty, project complexity, and product development project execution: a deeper look at task uncertainty in product innovation. Engineering Management IEEE Transactions on. Feb 2000.

THE FRONTIERS OF PROJECT MANAGEMENT RESEARCH. Editado por Dennis P. Slevin; David I. Cleland e Jeffrey K. Pinto. Project Management Institute, 2002.

THOMITOCLEOS, G.; WEARNE, S.H. Project management topic coverage in journals. Journal of Project Management, 18(1), 2000

THOMAS, J.L. Making sense of project management: contingency and sensemaking in transitory organizations. Thesis for the degree of Doctor of Philosophy. Faculty of Graduate Studies and Research, University of Alberta, Edmonton, Alberta, Canada, 2000.

WESTERVELD, E. The Project Excellence Model: linking success criteria and critical success factors. International Journal of Project Management 21 (2003) 411-418

WHEELRIGHT,S; CLARK, K. Revolutionizing Product Development. The Free Press, 1992 
WILLIAMS, T. Assessing and moving on from the dominant Project management discourse in the light of Project overruns. IEEE Transactions on Engineering Management, Vol 52, no 4, November 2005.

WINTER, M.;SMITH, C.;MORRIS, P;CICMIL, S. Directions for future research in project management: the main findings of a UK government-funded research network. International Journal of Project Management, 24 (2006).

YIN, R.K. Estudo de caso: planejamento e métodos. 3a edição Bookman, 2005 


\section{Roteiro utilizado nas entrevistas}

\section{Dados do entrevistado}

\begin{tabular}{|l|}
\hline Nome: \\
\hline Cargo/Função/Área: \\
\hline Formação: \\
\hline Contato: \\
\hline
\end{tabular}

\section{Características gerais da empresa}

\begin{tabular}{|l|}
\hline Empresa: \\
\hline Histórico (fundação, operações no Brasil, etc): \\
\hline Estrutura de capital (nacionalidades): \\
\hline Faturamento anual (2003-2007): \\
\hline Número de funcionários: \\
Total: \\
\hline
\end{tabular}

\section{Projetos}

\section{Descrição do processo de análise inicial}

-Verificar se existem categorias pré-determinadas para classificação de projetos

-Verificar como ocorre a comunicação do tipo de projeto entre exedcutivos e equipes de projeto

-Verificar se existe um processo formal de análise da complexidade e incerteza dos projetos

\section{Adaptação da gestão de projetos}

-Identificar como se dá a adaptação, observando os seguintes pontos 
- Organização

- Uso de metodologia de GP

o Alocação do gestor

o Nível de formalidade

o Reportes e comunicação

- Gestão de requisitos

o Uso de protótipos de mercado

o Momento de congelamento dos requisitos

o Quantidade de iterações

- Uso de pesquisa mercado/usuários

o Uso de contingenciamentos

- Criação e Construção do produto

o Possibilidade de erros técnicos e deempenho ruim

o Momento de congelamento dos requisitos

- Avaliação de capacitação técnica

o Uso de contingenciamentos

- Replanejamento

o Gestão de mudanças

o Flexibilidade

o Atualizações de projeto

o Improvisações

\section{Critérios de sucesso}

-Identificar os critérios de sucesso utilizados pela empresa nos projetos (eficiência, impacto no consumidor, impacto na equipe, negócios, preparação para o futuro, outros)

-Verificar o peso destes critérios em projetos considerados complexos e incertos -Verificar como a empresa efetua as medições destes critérios (momento, periodicidade) -Verificar se o gerente de projetos responde pelo projeto + produto. Se não, quais são as responsabilidades do gerente de projeto. 